\title{
Designing For Destruction: Anticipating Architectural Dismantling Through the Act of Making
}

by

Colleen McKeracher

A thesis submitted to the Faculty of

Graduate and Post Doctoral Affairs in partial

fulfillment of the requirements for the degree of Master of Architecture

Carleton University Ottawa, Ontario

(c) Colleen McKeracher 2014 


\begin{abstract}
This thesis proposes that architecture should be re-examined in terms of its own inevitable future material demise. Architects are predisposed to focus on the making and construction of buildings, and seldom consider the questions of demolition, destruction, and disassembly. However a more holistic approach to the making of buildings pursues construction, deconstruction, and reconstruction as a cyclical material system where consumption is always followed by reuse. Such an approach would result in designs that are prepared for future disassembly. Urban processes should also be considered as cyclical systems, in which periodic demolitions, and even destructions, create the conditions for urban rebirth. The ideas discovered in this thesis will be applied to the design of a new headquarters for the National Demolition Association, on a site in Detroit.
\end{abstract}




\section{Acknowledgements}

I would like to thank my thesis advisor, Janine Debanné for leading me through the thesis process, providing a wealth of knowledge and ideas, and for the time and effort she put into ensuring the success of my project. I would also like to thank Robert Shemiot for his guidance through the city of Detroit and his wonderful suggestions at the inception of this thesis.

Finally I'd like to extend my enormous appreciation for my family; my partner Nicholas O'Gorman and my parents Collette Yvonne and Peter McKeracher for their unflinching support without them this milestone would not be possible. 


\section{Table of Contents}

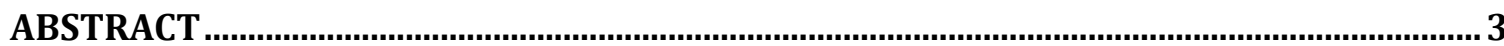

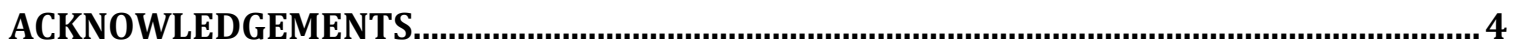

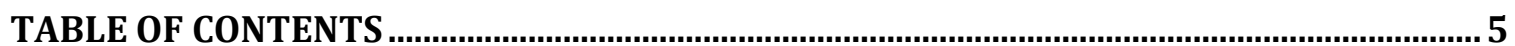

PART ONE

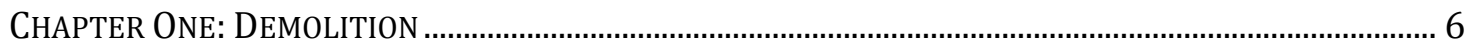

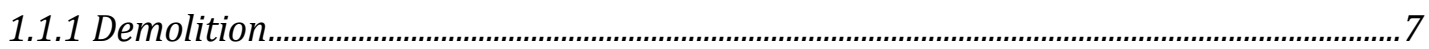

1.1.2 Statement of the Problem ......................................................................................................... 15

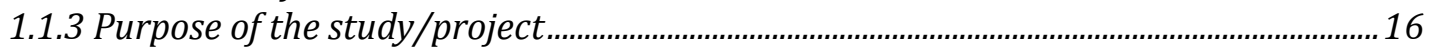

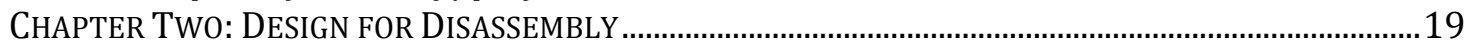

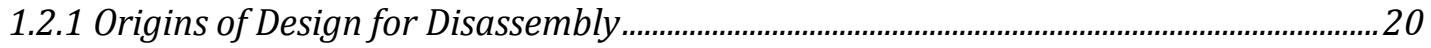

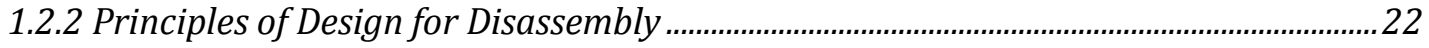

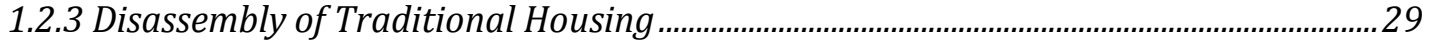

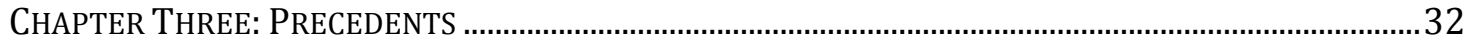

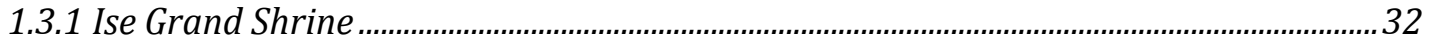

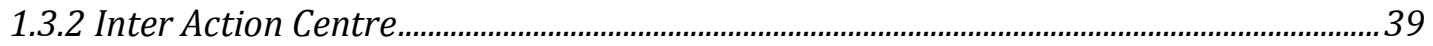

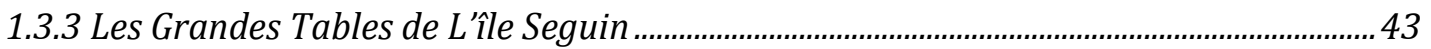

1.3.4 Summary

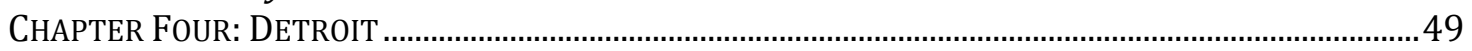

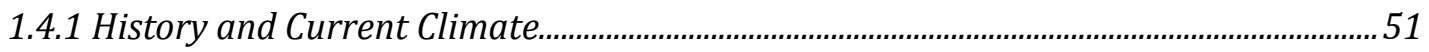

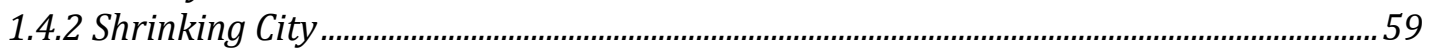

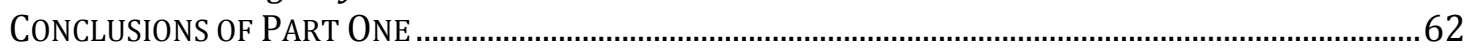

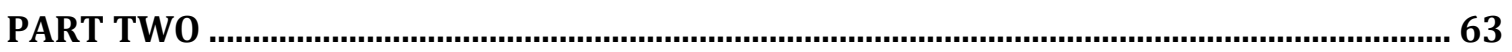

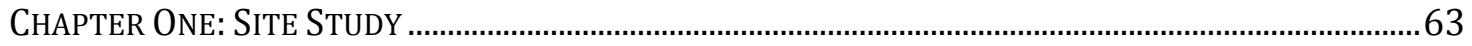

2.1.1 Site Context

2.1.2 Site Assets and Anticipated Developments by the City of Detroit...................................67

2.1.3 Site History: The Detroit Screw Works and Other Notable Past Structures.................. 72

Chapter TWO: D BuILD DETRoit, AN ARChiteCTURAL PROPOSAL........................................................78

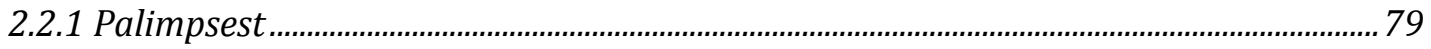

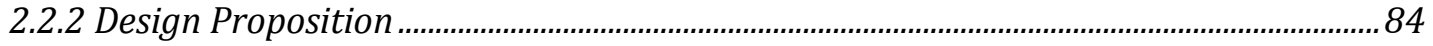

2.2.3 Program: List and Justification of Programmatic Elements .............................................. 88

2.2.4 Design Approach: Site Massing and Parti ...................................................................... 94

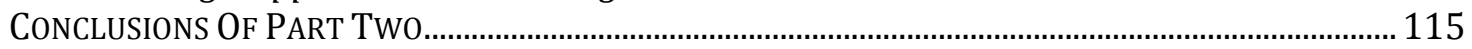

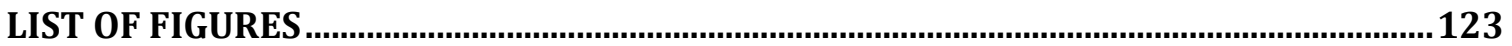

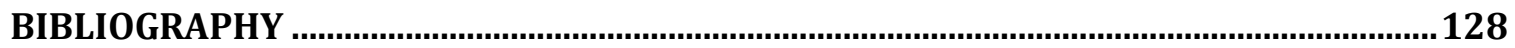




\section{Part One}

\section{Chapter One: Demolition}

\section{"such a renewal resumes the perpetual cycle of construction, deconstruction, reconstruction that has been suspended out of fear of our own inferiority." -Rem Koolhaas, 1991}

It is truly humbling to know that all our endeavors will eventually be engulfed by the vastness of space and time, and yet humans seemingly feel a deep and profound need to make an immortal mark on the world. Architects use their creations to achieve a sense of tactile permanence, as exemplified in the concept of firmitas, one of Vitruvius's three qualities of architecture. Firmitas is the building's ability to "endure based on its own material strength and soundness of construction" ${ }^{1}$ and was considered by Vitruvius to be a measure of architectural success. In contrast, many modern architects have acknowledged the mortality of architecture itself, but ideals of permanence still pervade our architectural values and practices.

The reality is, however, that the transient nature of our society demands that destruction make way for new forms as the progression of style and changing property values constantly redefine what is in vogue. Architecture designed for material permanence becomes a hindrance for future generations as they seek to continue the natural cycle of construction, deconstruction, and reconstruction in sustainable ways. Ignoring the cyclical nature of building produces conflict between

\footnotetext{
${ }^{1}$ Katrina Touw, "Firmitas Re-Visited: Permanence in Contemporary Architecture" (master's thesis, University of Waterloo, 2006), 3.
} 
the role of the architect and the role of the wrecker, as both operate under a limited scope of understanding and neglect crucial aspects of reconstruction. Architects typically see solutions to social, environmental, and cultural issues solely in terms of growth and development. Rarely in the history of architecture has the examination of post-occupancy and of building demolition been of central concern in architectural design and practice.

The life expectancy of our modern buildings is growing increasingly shorter, however, our social climate is developing faster and faster. Buildings are being demolished well before their materials have been used to their full potential, yet conventional buildings' constructions are often too permanent to allow for the disassembly of useful materials in an economical way. In order to complete the cycle of creation, destruction, and reconstruction, the architect must gain the insight of the wrecker and design accordingly. Taking into account that the afterlife of their creations will help to achieve a sustainable system of material use. This dissertation reevaluates permanence from a trans-historical approach, assesses the cycle of creation, destruction, and reconstruction within architecture, and asserts the potential of decline in urban climates.

\subsubsection{Demolition}

The natural world provides a model for the positive role played by destructive events. Forest fires cause devastation and displace inhabitants, but they also clear out old growth and create open space-and rich soil—for new growth. The destruction is, therefore, both advantageous and necessary for renewal. If we 
apply this same principle to the urban fabric, we can appreciate the necessity of periodic demolitions. Wars and natural disasters, as counterparts to forest fires, can also stimulate rebuilding cycles in urban centers, but areas that have been protected from destruction for too long will stagnate, resulting in unyielding amounts of decaying building stock. These cities will find themselves unable to easily adapt to progressive technologies and city forms. When Baron Haussmann forced a reconstruction upon the old fabric of Paris in $1853^{2}$, he ensured that the city would was able to accommodate the imminent demands of vehicle traffic and density, which modernized the city and made it the envy of all city capitals. But in his attempts to reconstruct the city he displaced entire neighbourhoods and removed many beloved buildings and streets causing human misery and resentment. ${ }^{3}$ The devastation and loss caused by deconstruction is unfortunate but it is necessary to create the conditions of reconstruction, and the opportunity to redesign in alignment with current conditions.

Historically, demolition was truly construction in reverse; the materials were easily salvaged and sold. In fact, up until 1925, American wreckers paid owners for the right to demolish a building in order to gain access to salvage materials. ${ }^{4}$ Changes to building materials, however, transformed the demolition industry, as soft and pliable binding materials such as lime mortar were replaced with hard and permanent materials like Portland cement. The use of hard-curing cements, steel,

\footnotetext{
${ }^{2}$ Brian Chapman, "Baron Haussmann and the Planning of Paris," The Town Planning Review 24, no. 3 (1953): 177.

${ }^{3}$ David P Jordan, Transforming Paris: The Life and Labors of Baron Haussmann (New York: Free Press, 1995), 371.

${ }^{4}$ Jeff Byles, Rubble: Unearthing the History of Demolition (New York: Harmony Books, 2005), 45.
} 
and other unyielding materials meant that modern demolitions required more time and energy. Rising wages made it difficult for wrecking contractors to pay for the labourers that deconstruction requires. Coupled with a weakened market for salvage materials since mass production had created competitive pricing for brand new materials, the wrecking industry regressed to simply bludgeoning the detritus away, with little concern for reuse potential. ${ }^{5}$ More recently, environmental regulations brought the practices of waste separation into the public eye and so once again material salvage is considered as a means to efficient demolition practices, especially when regional regulations impose waste limits, but when single-use disposable materials such as concrete, spray-foam, and sealants are used, the wreckers have no alternative but to resort to landfills. Today, comparatively low wages in a weakened economy could allow for the reintroduction of deconstruction practices but is impeded by a lack of experience and knowledge on demolition sites. Designers who fail to consider the eventual demise of their buildings are, therefore, at fault in the problem of demolition waste.

Illegal salvage, stripping abandoned buildings of their valuable metals is a worthwhile venture for those willing to labour in the removal of the goods and avoid the law. In Detroit avoiding the law is only too easy and illegal salvaging has become a widespread problem, especially when scrappers target historical buildings that lacking the security to protect their valuable ornamentation and quality fixtures. Scrappers leave these buildings without proper protection or structure, making them vulnerable to decay. The enterprising spirit of these

\footnotetext{
${ }^{5}$ Byles, Rubble, 45 .
} 
scrappers is characteristic of capitalism, yet the illegal nature of this salvage is a destructive force rather than a force for reconstruction.

Extreme population booms and advancements in construction allowed expansive metropolises to appear almost immediately in post-war North America. Wartime innovations in prefabricated housing materials such as laminated wood roofs and welded-steel roof trusses ${ }^{6}$ allowed speedy construction. Factories that had previously manufactured armaments were now readily equipped to produce building materials in vast quantities. Producing houses on an assembly line provided a quick return on property investments and companies like Levitt \& sons made a fortune selling their Levittown developments to returning veterans. ${ }^{7}$ Cities like Detroit and Houston annexed large amounts of land, doubling their area in the years following the first World War (FIG. 1 and FIG. 2), and that abundance of land, coupled with a rise in car ownership, allowed these cities to create large residentialonly neighbourhoods that sprawled outwards away from the city core, serviced by new highway infrastructure. The population densities of Detroit and Houston are among the lowest in North America.

Designers gave very little consideration to the future demise of these neighbourhoods. As these low-cost mass-produced family home neighbourhoods age with few institutional or commercial amenities to support the area it suffers drastically reduced property values creating little incentive to spend money and renovate the houses. Eventually living conditions become unbearable and homes are

\footnotetext{
6 Touw, "Firmitas," 244.

${ }^{7}$ Lynne Matarrese, "A Brief History of Levittown, New York," Levittown Historical Society. http://www.levittownhistoricalsociety.org/history.htm.
} 
abandoned in droves. In cities like Detroit and Houston, there are numerous examples of neighbourhoods with a high percentage of abandoned buildings. For instance, neighbourhoods such as Houston's Fifth Ward ${ }^{8}$ and the neighbourhoods of Detroit's east side have multiple vacancy rates exceeding $30 \% .{ }^{9}$ Abandoned houses constitute both a financial burden and a safety risk. Inadequate tax revenue on depressed property values impedes a city's ability to offset its service costs. Even just one abandoned house on a block decreases property values and lowers tax revenue. Meanwhile, water leaks in abandoned houses can go unnoticed for years, wasting municipal resources. Vacant homes also attract vagrants and vandals, which can create public safety hazards, and intimidates investors seeking to buy into areas with promising growth potential.

For these reasons, large-scale demolitions in depressed neighbourhoods are desirable, and have a positive impact on neighbouring areas. For instance, in 2013, the Detroit Blight Authority, a non-profit organization, conducted a massive demolition effort in the Brightmoor area, clearing ten blocks in ten days (FIG. 3). This has resulted in an immediate reduction of illegal dumping, and crime in the area ${ }^{10}$ and now the neighbourhood holds tremendous promise for the future of the area.

\footnotetext{
8Minh Dam, "Fifth Ward Neighborhood Undergoes Renaissance," Houston Chronicle, April 7, 2013, http://www.houstonchronicle.com.

${ }^{9}$ Courtney Flynn, "Taking Stock of Detroit Neighborhoods," Drawing Detroit, July 15, 2012, http://drawingdetroit.wordpress.com/2012/07/.

10 Joann Muller, "Bill Pulte: From Home Builder to Detroit's Unlikely Blight Buster," Forbes, October 9 , 2013, http://www.forbes.com/sites/joannmuller/2013/10/09/bill-pulte-detroits-unlikely-blightbuster/.
} 
Demolition is often considered negatively, commonly associated with the wrecking ball that is used to smash apart large high-rises and with its role in the destruction of historical architecture, and yet wherever demolition is present it is usually a sign of new economic activity in the area. The National Demolition Association uses the motto "Making Way" to characterize their profession and is constantly working towards a positive image for their industry. ${ }^{11}$

Our society is leaving many problems for future generations. As the effects of overpopulation and pollution intensify, there is a growing need for architecture and urban planning to become more attuned to environmental concerns. Architecture that seriously considers its eventual demise could set an example for all future building and planning. It is the responsibility of creators to anticipate demolition and allow for reconstruction.

${ }^{11}$ National Demolition Association website, accessed February 13, 2014, https://www.demolitionassociation.com/. 


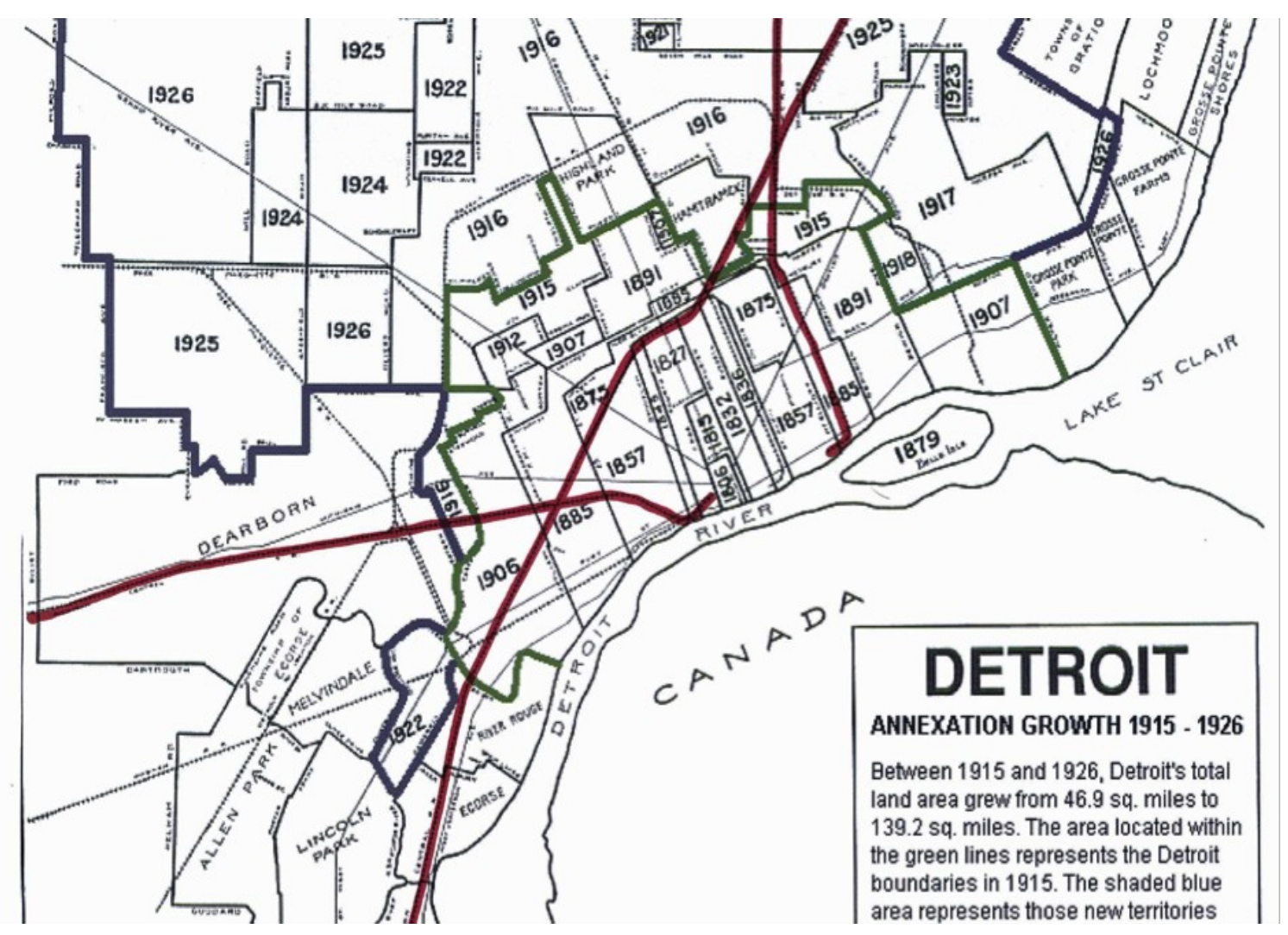

FIG. 1 DETROIT ANNEXATION GROWTH 1915 - 1926: Saunder, Pete. The Reasons behind Detroit's Decline. Last Modified February 21st 2012. Accessed February 2014 <http://www.urbanophile.com/2012/02/21/the-reasons-behind-detroits-decline-by-pete-saunders/>. 


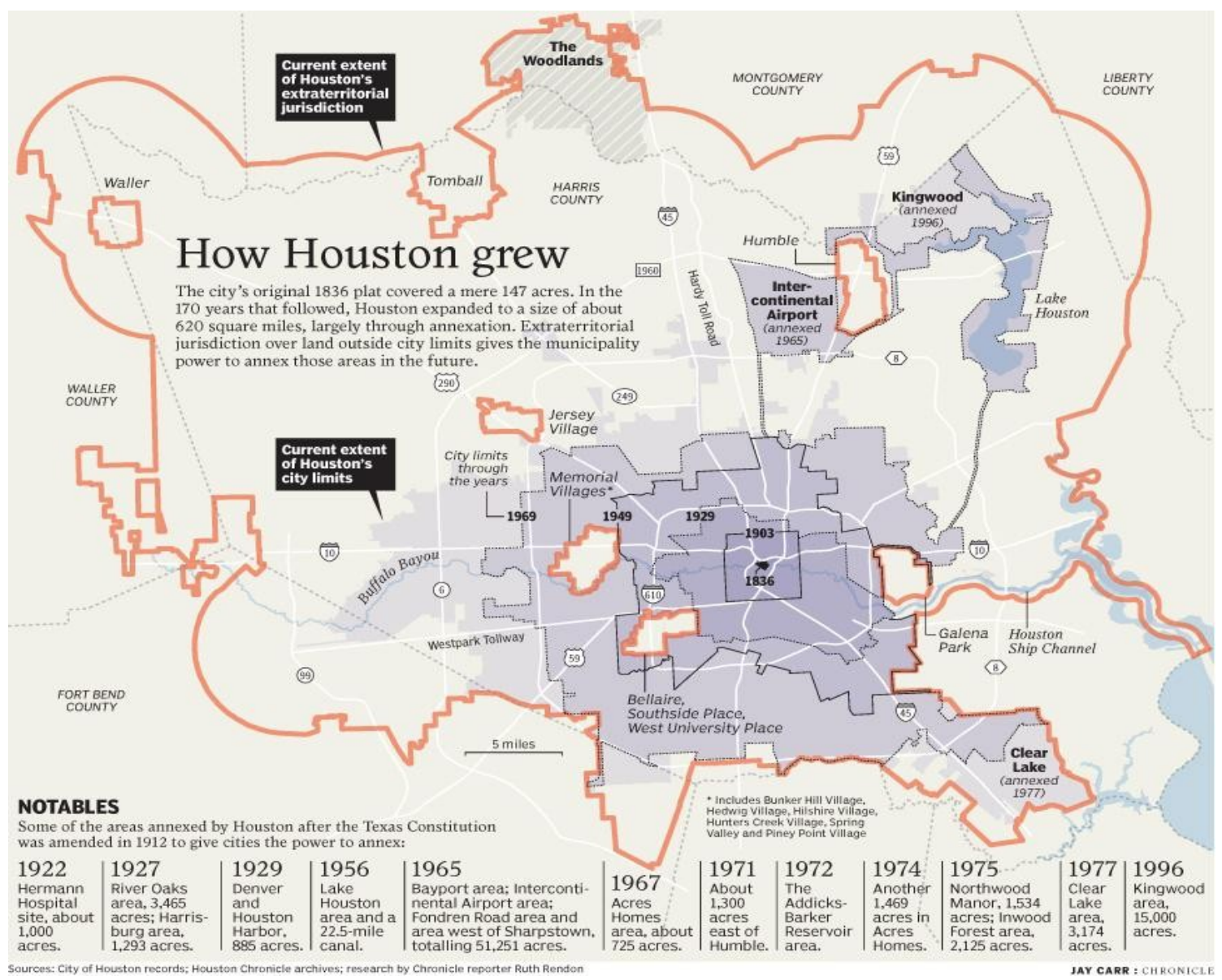

FIG. 2 HOW HOUSTON GREW: Carr, Jay. HOUSTON AT 175 How Houston Grew. Houston Chronicle: 22. 2011.

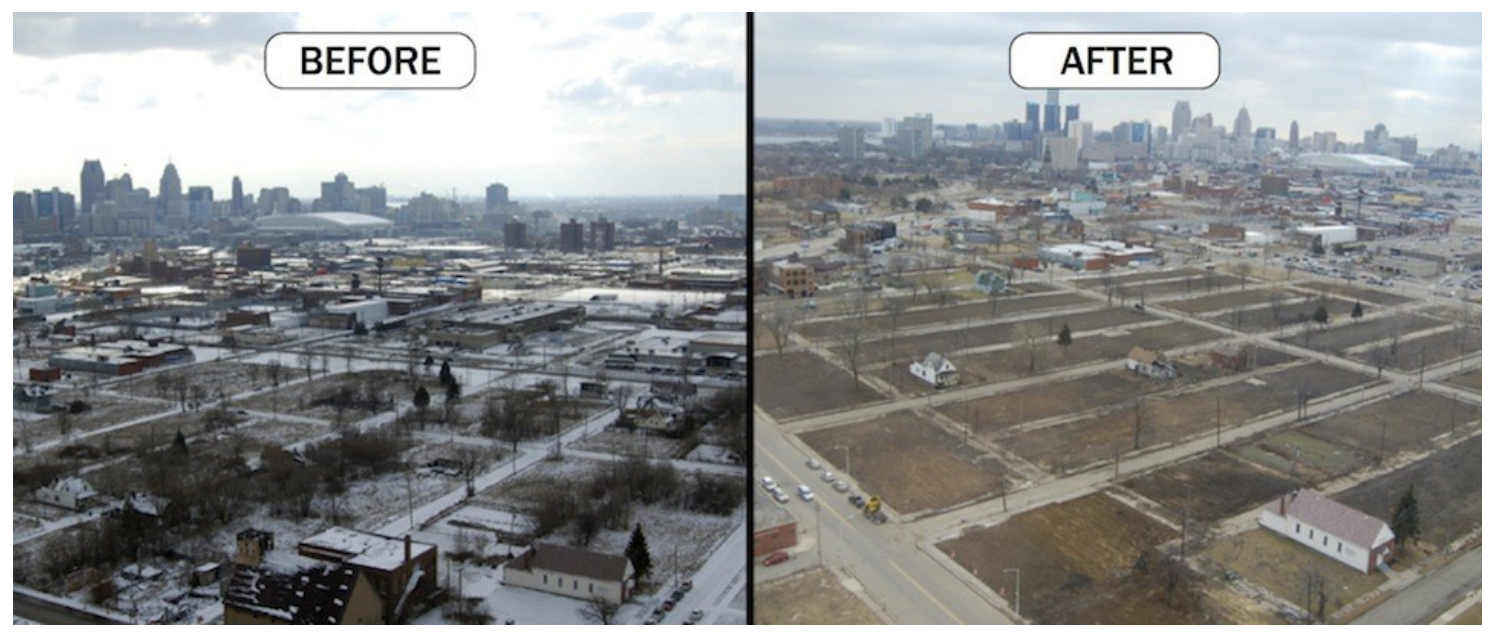

FIG. 3 SKYLINE: "Detroit Blight Authority." Photos. N.p., n.d. Web. 13 Feb. 2014. 


\subsubsection{Statement of the Problem}

Demolition will inevitably lead to unwanted materials that become waste, and even the most thoughtful architecture cannot expect to be $100 \%$ reusable. Population growth is at the root of our waste problem, and many people believe "we have now passed the limits of our planet's capacity to support us."12 Our human desire to consume, our preference for new products, and an economic system that values growth as the only measure of success, proliferates the creation of waste. Our economy depends on planned obsolescence, whether by instilling the idea that the newer products are inherently better or by having products break prematurely, necessitating their replacement. Yearly restyling of car models was innovated by General Motors head Alfred P. Sloan in order to convince a saturated market that it was necessary to buy replacement cars. ${ }^{13}$ Henry Ford opposed this marketing style, instead relying on design integrity, and consequently General Motors became the market leader in $1931 .{ }^{14}$ Planned obsolescence will ensure that our technology will continue to supersede itself indefinitely, creating an endless parade of obsolete products in its wake. Engineering products that lose value before it is absolutely necessary is not just inefficient, but also creates unnecessary waste.

In the European Union, it is estimated that construction and demolition is responsible for $30 \%$ of the total waste generated. ${ }^{15}$ Waste materials degrade our

\footnotetext{
${ }^{12}$ Steffen Lehmann and Robert Crocker, Designing for Zero Waste: Consumption, Technologies and the Built Environment (London: EarthScan, 2012), 1.

${ }^{13}$ Giles Slade, Made to break: technology and obsolescence in America, (Cambridge, Mass.: Harvard University Press, 2006)

14 Ibid

15 Michael Hiete, Julian Stengel, Jens Ludwig, and Frank Schultmann, "Matching Construction and Demolition Waste Supply to Recycling Demand: A Regional Management Chain Model," Building Research \& Information 39, no.4 (2011): 334.
} 
natural habitat and deplete our natural resources, ${ }^{16}$ but the production of waste is on the rise. The Organization for Economic Co-operation and Development notes that "a sharp increase in C\&DW is predicted for this century. It is estimated that demolition waste generated in the European Union will increase from $160 \mathrm{Mt}$ (Million tonnes) in 1995 to $330 \mathrm{Mt}$ in 2010 and $500 \mathrm{Mt}$ in 2060."17 Other countries have already adopted strategies to reduce C \& D waste, in Japan, the overall recycling of C \& D waste reached an unprecedented $95 \%$ in 2010.18

Current practice is to locate landfills outside of cities and beyond our usual travel routes. This invisibility helps to conceal the waste problem, and our ignorance encourages neglect. A new appreciation for the problem must be experienced in order to shift the paradigm of our material flow.

\subsubsection{Purpose of the study/project}

The currently accepted system for rating sustainable architecture practice in Canada is Leadership in Energy and Environmental Design (LEED). This rating system focuses on the environmental issues surrounding the construction and operation of buildings, but the requirements for the reduction of eventual demolition waste in new designs are insignificant. A building can gain one LEED point if it is considered durable, thereby avoiding premature failure of the building Yet a recent study has shown that physical condition is not the leading cause of

\footnotetext{
${ }^{16}$ Lehmann and Crocker.

${ }_{17}$ OECD, Environmentally Sustainable Buildings, Challenges and Policies (OECD Publishing, 2003), 27. ${ }^{18}$ Anton Ming-Zhi, "Construction \& Demolition Waste Management: From Japan to Hong Kong". 2006. Griffin's View on International and Comparative Law. 7 (2): 15-45.
} 
demolition. ${ }^{19}$ Only $30.8 \%$ of the buildings surveyed were demolished because of their physical condition, and only 3.5\% of demolitions were due to a failure of the structure, materials, or other systems. Predominantly, buildings are not demolished for their lack of durability but instead because of factors such as the building's suitability for the occupants or because the land holds more value as a new development. These factors are unpredictable and therefore difficult to plan for at the design stage and so a building's ability to adapt to future needs or to be disassembled for material reuse is far more valuable to environmental design than its durability.

On the other hand, LEED does offer points for incorporating recycled and reused materials, which will unquestionably encourage the use of salvage in new designs and divert waste from landfills. The Canadian Green Building Council claims that since 2005 LEED Canada's policies have resulted in the "recycling [of] over two million tonnes of construction/demolition waste."20 This statistic is evidence that controlling demolition waste is important to LEED's vision for sustainable practice, and yet the rating system does not reward constructions that design for disassembly. New constructions should also demonstrate that they can provide as much reusable and recyclable materials as possible at the end of their life cycle in order to complete the cycle of diverting waste from landfills. This thesis hopes to develop a design that would maximize the salvage potential in architectural creations and in the

\footnotetext{
${ }^{19}$ J. O'Connor, "Survey on Actual Service Lives for North America Buildings" (paper presented at Woodframe Housing Durability and Disaster Issues Conference, Las Vegas, October 2004).

20 "Going Green with LEED." Canada Green Building Council, accessed March 22, 2014, http://www.cagbc.org/Content/NavigationMenu/Programs/LEED/GoingGreenwithLEED/default.ht m.
} 
surrounding urban environment, as well as to promote designs that anticipate demolition as a major consideration in the assessment of sustainable architectural practice. 


\section{Chapter Two: Design for Disassembly}

"How many of these buildings deserve eternal life? This question is essentially forbidden in Europe, where urban context is assumed to be something that should be preserved and respected, not destroyed. In many cases, of course, that is entirely legitimate. But when we look at these buildings - their materials not intended to last forever, their programs merely articulations of a momentary financial legitimacy-it became difficult to consider them part of Europe in a historical sense. They were not conceived with claims of permanence; they are a kind of provisional-short-termarchitecture." -Rem Koolhaas, 1991

Now that sustainable design has taken prominence in building research, Design for Disassembly is an increasingly important concept in the building industry, encouraging the careful selection and implementation of materials so that they may be recovered during eventual reconstruction or deconstruction. The intention in doing so is to divert waste from landfills and create value in a building at the end of its life. The amortization of a typical home mortgage is thirty years, while the average age of residential home in Canada is eighteen years old, providing an indication of the average service life midpoint and proving that the actual service life of a house will likely endure just long enough for it to be paid off. ${ }^{21}$ The housing market, location, and physical condition of the building in question will ultimately decide the property's value after twenty-five years, so a house with recoverable assets in the salvage of its materials could provide some guarantee on the enormous investment of a home. As it stands now, however, property insurance is the only way to recover any of the financial investment when property values drop significantly.

21 O’Connor, "Survey on Actual Service Lives." 


\subsubsection{Origins of Design for Disassembly}

Notions of decay and renewal have been prevalent in architectural theory since the inauguration of the Metabolist movement in Japan in the wake of World War II. The destructive impact of the war upon the built environment stressed the impermanence of architecture to the founders of the Metabolist movement and the fire bombing of predominantly wood built structures as well as the completely leveling of cities by the atomic bomb generated a need for urban redevelopment on an unprecedented scale. ${ }^{22}$ Their philosophy has been described thus: "Everything we see is impermanent. Whole cities can vanish in a day of warfare. It's this idea that the Japanese believe in, not the outward form. It's the philosophy."23 Japanese architects were called upon to innovate new solutions when a population boom in the 1950's created a land shortage problem. Their modernist vision revealed an architectural language of massive structural armatures, in which replaceable capsules could plug into components that could disengage from the core, without damage. This corresponds to the basic ideas of Design for Disassembly, allowing for the economical recovery of materials.

The groups title, Metabolism, is translated from the Japanese word shinchintaisha, which carries the meaning of "replacement of the old with the new,"24 and so Metabolist architects recognize the continuous cycle of death that feeds rebirth as the fundamental philosophy guiding their designs. Their designs propose ideas such as self-renewal every fifty years, influenced by traditional

\footnotetext{
22 Rem Koolhaas and Hans-Ulrich Obrist, Project Japan: Metabolism Talks, ed. Kayoko Ota and James Westcott (Köln: Taschen, 2011).

23 Ibid., 383.

${ }^{24}$ Ibid., 235.
} 
Japanese precedents like the Ise Shrine, which undergoes a complete self-renewal every twenty years. Kisho Kurokawa, a founder of the Metabolists compared the groups revolutionary ideology against prevailing architecture thought; "European beauty was supposed to be eternal, but perhaps we could discover a new aesthetic based on movement."25

In the West, post-war developments in lightweight steel technology allowed architects like Buckminster Fuller to experiment with prefabricated materials. These prefabricated builds were constructed component by component and presented an alternative approach to traditional architectural design. Cedric Price, a British post-war architect, embraced this new technology and the new ideas that challenged traditional architectural culture, which was obsessed with form. ${ }^{26}$ Price's designs were governed by their ability to perform for the user, virtually "relinquishing the patriarchal role of the architect as omniscient form-giver and instead permitting users the freedom to control and shape their environment."27 Like the Metabolists, Price had also witnessed the ruins of a war-ravaged city and came to recognize the inevitable impermanence of structure. The flexibility in his architectural work embodied the rapid development and transience of modern postwar society, and will be explored further in the precedents section of this thesis.

Similar ideas can be seen in the "Plug-in City," a work imagined by Archigram members Warren Chalk, Peter Cook, and Dennis Crompton. This design had the ability to transform in order to suit the user's needs. Price has been referred to as

\footnotetext{
25 Koolhaas and Obrist, Project Japan, 383.

26 J. Stanley Mathews, From Agit-Prop to Free Space: The Architecture of Cedric Price (London: Black Dog, 2007).

27 Ibid., 24
} 
the group's 'guru', providing inspiration and support to Archigram after Price and Cook met as students at the Architectural Association. ${ }^{28 ~ " P l u g-i n ~ C i t y " ~ w a s ~}$ conceived in 1964 as a large-scale network-structure into which "units" were plugged. This project is concerned with decay and obsolescence, proposing a range of life cycles for every component. The framework allows the components to be salvaged when dismantling the outdated parts, and new parts could be installed into the existing structure without the use of destructive force. The life cycle of the main megastructure could last forty years, while bathrooms and kitchens would be restored every three years and the living rooms every five to eight years. ${ }^{29}$

These architects understood the changes that rapidly evolving technology would demand on our environment and imagined how architecture could evolve to adapt to an unknown future. Price called this "anticipatory architecture,"30 that is, architecture that would "maximize the possible." ${ }^{1}$ Design for Disassembly builds on these ideas by similarly stressing the importance of impermanence in architectural design and utilizing aspects that allow for a sustainable model of waste reclamation.

\subsubsection{Principles of Design for Disassembly}

Set out by the Canadian Standards Association, the Principles of Design for Disassembly help to guide designs in order to recover as many reusable or recyclable components in the most economical way. Recovering all of a building's

\footnotetext{
28 Ibid.

${ }^{29}$ Peter Cook, Archigram (New York: Princeton Architectural, 1999).

30 Mathews, From Agit-Prop to Free Space, 41.

31 Ibid.
} 
materials is an impossible endeavor as many mechanical or electrical components become obsolete very quickly and other materials, such as washers and nails, are too small to recover with any sort of cost efficiency. The CSA's principles aim, however, to maximize recovery. The eleven principles are: Accessibility, Documentation of Disassembly Information, Durability, Exposed and/or Reversible Connections, Independence, Inherent Finishes, Recyclability, Refurnishabilty, Remanufacturability, Reusability, and Simplicity.

\section{Accessibility}

Accessible components allow for maintenance or replacement of subcomponents without damage to surrounding materials. Accessibility also allows for regular visual inspections, which serve as a preventative measure against deterioration. Innovative technology means that accessibility need not detract from aesthetic considerations. For instance, the Green-zip tape partition system allows drywall to be demounted and remounted while still maintaining the seamless surface that is expected of interior walls, but when expressive connections are utilized they assert the architects' values towards deconstructable design.

\section{Documentation of Disassembly Information}

Accurate and complete documentation of buildings designed for disassembly is absolutely crucial to ensuring the demolition fulfills the design intent. Unless efforts made during the design phase are communicated clearly, the effort will have been in vain. Each material should be catalogued individually, and information such 
as the date of manufacture, structural and material components, and the manufacturer's contact information will help indicate each component's value. This information can be included in the building's drawing set or on the material itself, using codes or even computer chips. Building Information Modeling is a recent development in architectural drawing technology that can aid in this endeavor. Keeping the drawing set current with renovations and repairs will maintain accuracy, and storage both on site physically and electronically will prevent them from becoming lost or forgotten. Drawings that include information about the sequence and methods of construction will further communicate the architects' intent to disassemble.

\section{Durability}

The longevity of a material will significantly increase the performance and service life of a building. In addition to being physically durable, materials should be fashionably durable. Trendy architecture is likely to become passé faster and drop the aesthetic value of a building. In North American buildings are demolished well before their conceivable service life and retail structures provide an example of this phenomenon. Major retailers are particularly conscious of their aesthetic appeal because they expect their architecture to convey a sense of the "avant-garde" in order to attract customers. Big box stores are built in the expectation of shorter lifespans, and are consequently constructed with lower-priced, non-durable 
materials. ${ }^{32}$ Once the retailer abandons the structure, the building tends to fail quickly and becomes a burden on the urban landscape it occupies. ${ }^{33}$ These buildings could be adapted for new uses but the design decisions to use materials that were non-durable ensures that they will instead become unrecoverable waste materials. If instead these structures were designed to be durable, the materials could be recovered and re-introduced to the material stream creating an efficient use of embodied energy.

\section{Exposed and/or reversible connections}

Disassembly relies on the ease with which components can be separated in order for them to be a viable material for the end-user. The popular electronic manufacturer Apple requires special tools and knowledge in order to open the cases of their small electronics. These obstacles are set in place to help to convince the consumer to buy a whole new product instead of doing self-repairs or upgrades. In contrast, when users can visually understand exposed connections the product is authorizing their access. Space around the connections is key to ensuring the component can be removed without damaging neighbouring materials. Durable reversible connectors like bolts and screws are valuable because they can tolerate repeated usage. Common connectors are preferable as they do not require special tools or knowledge to operate. Connectors that have universal sizes and mechanisms are easily replaced or adapted into new projects. On the other hand,

\footnotetext{
32 John Olsen, "Urban Landscapes," The Life and Death of the Big Box, January 31, 2011, http://urbanlandscapes.info/2011/01/31/the-life-and-death-of-the-big-box. 33 Ibid.
} 
permanent connections created by chemicals or adhesives often contaminate the material, making it difficult to recycle, and separation of components is likely to destroy both components in the process.

\section{Independence}

Independence allows components to be adjusted, removed, replaced, or even upgraded, without interference from other building systems. Maintenance and replacement may require whole layers of the building to be separated. If access to a deficient layer is impeded, other layers might need to be removed too, or the entire building might even need to be demolished if reaching the deficient layer is not economically feasible. To use an idiomatic phrase, this amounts to throwing the baby out with the bathwater. When purging outdated or defective materials, conserving materials that still hold value will reduce waste, and this possibility therefore needs to be considered in the design phase. Architects can protect valuable materials by separating out layers, all without compromising the integration of systems. Creating the conditions for a parallel disassembly is advisable to ensure one layer's removal doesn't impede the entire deconstruction process.

\section{Inherent Finishes}

Choosing to alter the natural appearance of a material can have negative repercussions on that material's reusability and recyclability. Certain finishes might contaminate the material in irreversible ways, limiting future value. Materials that 
can be considered aesthetically appealing in their natural state are, therefore, the most appropriate choice for future disassembly potential. Finishes that have enduring aesthetic and physical characteristics are acceptable, but their future values will be more uncertain. Currently desirable finishes could become expensive obstacles during future disassembly.

\section{Recyclability}

Recyclable materials can be returned to the economy through existing processes and markets once they are recovered from the building. This reduces waste created from building demolition and prevents virgin resources from being used unnecessarily. There are economic benefits to using recyclable materials as well, since they retain value and can be sold immediately after removal.

\section{Refurnishabilty}

Refurbishable materials can regain their aesthetic and/or functional qualities. Refurbishment by the owner extends the life of a material and reduces waste by preventing the need to purchase complete replacements. The replacement of subcomponents creates some waste, but overall improvements may improve system efficiency and reduce energy consumption. Also, refurbishment is generally cheaper than replacement, and so is a cost-saving measure for owners. Many traditional materials, such as wooden floors or vintage furniture, are refurbishable. 


\section{Remanufacturability}

Much like refurnishability, remanufacturability restores a product to its original physical appearance or efficiency, but unlike refurbishing, the ownership of the product is transferred back to the original manufacturer or to a secondary party. Manufacturers who offer remanufacturable products design their products to facilitate disassembly and allow for repairs and upgrading, which ensures that the product can be restored to a like-new condition. Remanufacturability is appealing because it transfers the risk of prematurely lost value to the manufacturer, while still ensuring that unnecessary waste prevention. This provides a safe economic reward for end-users if they chose to disassemble their building.

\section{Reusability}

Careful disassembly is an expensive process and reusable materials offset these costs better than recyclable materials. Preventing waste is a key goal in reusing materials, but reuse also curtails the consumption of natural resources and reduces energy consumption and pollution created during manufacturing. When choosing materials that could be reused, future market values need to be predicted.

\section{Simplicity}

Simple designs reduce the amount of materials used, and reducing ornamental elements and the variety of material types ensures an uncomplicated disassembly. Standardization allows for cost-effective replacement of parts and produce a more desirable material for reuse. Standard sizes are not only 
economically practical but also reduce the amount of waste-producing offcuts at the factory or on site. The use of modular components ensures a repetitious disassembly procedure, expediting the process. Meanwhile, the value of a large stock of matching components is much higher and therefore is a more enticing product for potential buyers.

\subsubsection{Disassembly of Traditional Housing}

In 1996, the Canadian Mortgage and Housing Corporation documented the deconstruction of a house in Ottawa and published the results. The house on 1659 Kilborn Avenue was in poor condition, suffering from vandalism and fire damage, and still managed to generate $\$ 10,000$ from the reclaimed materials. When the material revenues were tallied, wood had the highest revenue, while concrete had the lowest (FIG. 5). Wood has vast potential for reuse and recycling, whereas concrete's only reuse potential is as crushed aggregate, a low-value commodity. Concrete, however, was the predominant material in this project. Also, while the deconstruction approach generated more revenue than a traditional demolition, the labour was almost ten times more expensive (FIG. 4). As a result, the net costs of the deconstruction were higher than a traditional demolition.

Nevertheless, the benefits of this type of deconstruction, including additional employment and environmental conservation, provide incentives for thoughtful deconstruction. Moreover, this project demonstrates ways that revenues could be increased. Barriers to maximizing revenue were a lack of experience and knowledge within the demolition industry of the deconstruction approach, uncertainty about 
the reuse value of materials, liability issues, and a limited market capacity for salvage. The deconstruction of a house following principles of design for disassembly would be expected to produce higher revenues and to incur lower labour costs. This could make it more fiscally rewarding to deconstruct than to demolish.

TABLE 2: Comparative Cost Breakdown

\begin{tabular}{|l|r|}
\hline \multicolumn{2}{|l|}{ Deconstruction - Breakdown } \\
\hline Expense Description & \multicolumn{1}{l|}{ Amount } \\
\hline Labour & $\$ 27,300.00$ \\
\hline Licenses \& Permits & $\$ 400.00$ \\
\hline $\begin{array}{l}\text { Administration \& } \\
\text { Overhead }\end{array}$ & $\$ 5,700.00$ \\
\hline Materials \& Supplies & $\$ 1,600.00$ \\
\hline Equipment & $\$ 7,800.00$ \\
\hline Disposal & $\$ 1,200.00$ \\
\hline TOTAL EXPENSES & $\$ 44,000.00$ \\
\hline REVENUES & $\$ 10,000.00$ \\
\hline NET COST & $\$ \mathbf{3 4 , 0 0 0 . 0 0}$ \\
\hline
\end{tabular}

\begin{tabular}{|l|r|}
\hline \multicolumn{2}{|l|}{ Traditional Demolition - Breakdown } \\
\hline Expense Description & Amount \\
\hline Labour & $\$ 3,050.00$ \\
\hline Licenses \& Permits & $\$ 400.00$ \\
\hline $\begin{array}{l}\text { Administration \& } \\
\text { Overhead }\end{array}$ & $\$ 3700.00$ \\
\hline Materials \& Supplies & $\$ 800.00$ \\
\hline Equipment & $\$ 7,600.00$ \\
\hline Disposal & $\$ 12,000.00$ \\
\hline TOTAL & $\$ 27,550.00$ \\
\hline REVENUES & $\$ 550.00$ \\
\hline NET COST & $\$ 27,000.00$ \\
\hline
\end{tabular}

* The deconstruction cost above includes $\$ 5,000.00$ of added documentation costs which is not typical. The net cost without documentation costs would be $\$ 29,000.00$.

FIG. 4 COMPARATIVE COST BREAKDOWN: Marshall, Terry. Housing Deconstruction Project: 1659 Kilborn Avenue, Ottawa. CMHC. Ottawa, 1996. 
TABLE 3: Revenues Breakdown

\begin{tabular}{|l|c|c|c|l|l|}
\hline Material Category & \% Weight & Revenue & \% Revenue & Reuse & Recycle \\
\hline Wood & 11 & $\$ 5,020.00$ & 50 & Yes & Yes \\
\hline Doors \& Windows & 0.83 & $\$ 1,810.00$ & 18 & Yes & No \\
\hline Finishes & 1.5 & $\$ 800.00$ & 0.8 & Yes & No \\
\hline Furnishings & 2.5 & $\$ 640.00$ & 0.64 & Yes & No \\
\hline Metals & 2 & $\$ 520.00$ & 0.52 & Yes & Yes \\
\hline Mechanical & 0.2 & $\$ 340.00$ & 0.34 & Yes & No \\
\hline Insulation & 1.43 & $\$ 320.00$ & 0.32 & Yes & No \\
\hline Electrical & 0.23 & $\$ 310.00$ & 0.31 & Yes & No \\
\hline Concrete & 77 & $\$ 240.00$ & 0.24 & Yes & Yes \\
\hline Roof Membrane & 2.8 & $\$ 0.00$ & 0 & No & Yes \\
\hline
\end{tabular}

FIG. 5 REVENUES BREAKDOWN: Marshall, Terry. Housing Deconstruction Project: 1659 Kilborn Avenue, Ottawa. CMHC. Ottawa, 1996. 


\section{Chapter Three: Precedents}

"Buildings and cities must be able to adapt, grow, elevate, even float, if they are to survive the dual pressures of rapid modernization and inevitable natural change (usually calamitous)..." -Hans Ulrich Obrist, 2011

The operations and maintenance manual for the various systems within modern buildings tend to be massive tomes, despite the simplicity of the program, demonstrating how dependent our buildings have become on custodians. A modern building left abandoned would succumb to ruin much faster than its predecessors. Significant monumental architectural works of the past endured throughout the ages, slowing becoming less functional and more sculptural. The act of building monumental architecture was often considered an immortalizing endeavor, and the urge to create architecture that expresses that same grandeur can be enticing. Permanence in architecture, however, neglects the users' needs, and values form over function. Modern architecture, inspired by the realities of the machine age, is instead based on the idea that form follows function. Within the framework of planned obsolescence, our machines are doomed to fail, and an architecture built for those machines will undoubtedly fail with them. The following precedents embrace their temporal existence and thus are prepared for inevitable demolition.

\subsubsection{Ise Grand Shrine}

Periodic rebuilding of the Ise Grand Shrine in Japan began under Emperor 
Temmu's rule in $690 .{ }^{34}$ Located in the city of Ise in the prefecture of Mie, this shrine was built to aid in the practice of Shinto rituals, and it is considered to be one of their most important sites. ${ }^{35}$ The Ise Shrine is ceremonially rebuilt every twenty years in a ritual that lasts seventeen years in a tradition known as Sengu. ${ }^{36}$ Sengu is a custom that reinforces the Shinto understanding of life and death as a cyclical renewal, also known as Wabi-sabi. Wabi-sabi acknowledges the transient nature of life, death, and renewal, embracing impermanence and imperfection as reminders of mortality. According to Wabi-sabi, "nothing lasts, nothing is finished and nothing lasts forever."37

Sengu creates a period of renewal during which traditional building techniques are passed down to the next generation. The Ise Shrine is a large complex of shrine buildings divided into two main groups. The Naiku, or inner shrine, hosts the deity of the Sun Goddess Amaterasu Omikami, and the Geku, or outer shrine, hosts the Goddess of food, clothing, and shelter, Toyouke Omikami. ${ }^{38}$ The most recent rebuilding of the Naiku was completed on October 2nd, 2013, and three days later the Geku was completed, constituting the 62nd iteration of the Ise Shrine..$^{39}$ The adjacent site to each of the shrines is used for the next iteration so that the structures periodically alternate positions. During the process of installing the new shrine a completely different structure, known as the Suyane, is built over the

\footnotetext{
${ }^{34}$ William Howard Coaldrake, Architecture and Authority in Japan (London: Routledge, 2002), Taylor $\&$ Francis e-Library edition.

${ }^{35}$ Coaldrake, Architecture and Authority in Japan.

${ }^{36}$ Cassandra Adams, "Japan's Ise Shrine and its Thirteen-Hundred-Year-Old Reconstruction Tradition," Journal of Architectural Education 52, no. 1 (1998): 49-60.

37 Richard R. Powell, Wabi Sabi Simple (Avon, Mass.: Adams Media, 2005),19.

38 Florian Coulmas, "Eternal Change at the Grand Shrine of Ise." Japan Quarterly 41, no. 1 (1994): 36.

39 "Historic Ise Jingu Gears Up for Vicennial 'Big Move'," The Asahi Shimbun website, September 25, 2013, http://ajw.asahi.com/article/behind_news/AJ201309250062.
} 
entire site. ${ }^{40}$ The Suyane protects the new shrine from weather and animals, and effectively conceals it from the view of the public. It also serves to suspend a handoperated hoist that is necessary to install the heavy components, since no modern machinery may be used on site during the construction of the shrine.

The Suyane is no longer built in the same traditional manner of the shrine, however, but utilizes prefabricated modern materials. ${ }^{41}$ This change ensures the safety of the workers and the shrine during disassembly and reconstruction. The old shrines are disassembled carefully and any wood that has not decayed is reused in the repair and construction of the less sacred shrines. ${ }^{42}$ Historically, old wood has even been cut up and distributed to individual households. ${ }^{43}$ Once the new shrine is in place the ground is covered with white stones from the river in a ritual involving 173,000 participants. This is, however, not an original Sengu tradition but was added, a few centuries later, in order to celebrate the pilgrim donations that the shrines rely on during periods of decline. ${ }^{44}$

The Ise Shrine's architectural style is unique, and many of the buildings in the complex share similar features. Timber piles in the ground support their simple rectangular forms. The raised floors pull the building off the ground, protecting the site and structure from damage. A large ridge beam supports a roof made of thatched reeds. The timber selected for the shrines is Japanese cypress wood, also known as Hinoki, was originally procured from the surrounding forest but now to

\footnotetext{
40 Adams, "Japan's Ise Shrine."

41 Ibid. 57.

42 Ibid. 53.

43 Ibid. 53.

44 Ibid. 56.
} 
fulfill the demand timber must be brought in from all over Japan, and the trees chosen for shrine use are typically 300 to 500 years old. ${ }^{45}$

The construction techniques are a model of design for disassembly. The Japanese shrine and temple carpenters are renowned for their elaborate wooden joinery techniques. The joints they create are flexible and yet have enough strength to last a lifetime without the use of nails, screws, or adhesives. These types of connections are completely reversible and so any damaged components can be removed without damaging the surrounding components. The post and beam construction is an uncomplicated structural system and the limited materiality produces a simple design. Wood retains its value as a building material after use because it can be easily reshaped, and once it has lost its ability to function as a building material it returns to the ecosystem, deteriorating into the ground relatively quickly. The builders' intention to disassemble their final construction is made exceedingly clear through apprenticeships and rituals. Originally, the transmission of shrine building knowledge was strictly an oral traditional but after the Sengu was interrupted (from 1463 to 1585 ) due to civil war ${ }^{46}$, the advantages of comprehensive documentation became clear. Decorative finishes can be seen on the finials of the roof, but most of the wood has a natural finish and is therefore easily adapted to other purposes.

\footnotetext{
45 Ibid. 53.
}

${ }^{46}$ Ibid. 52. 


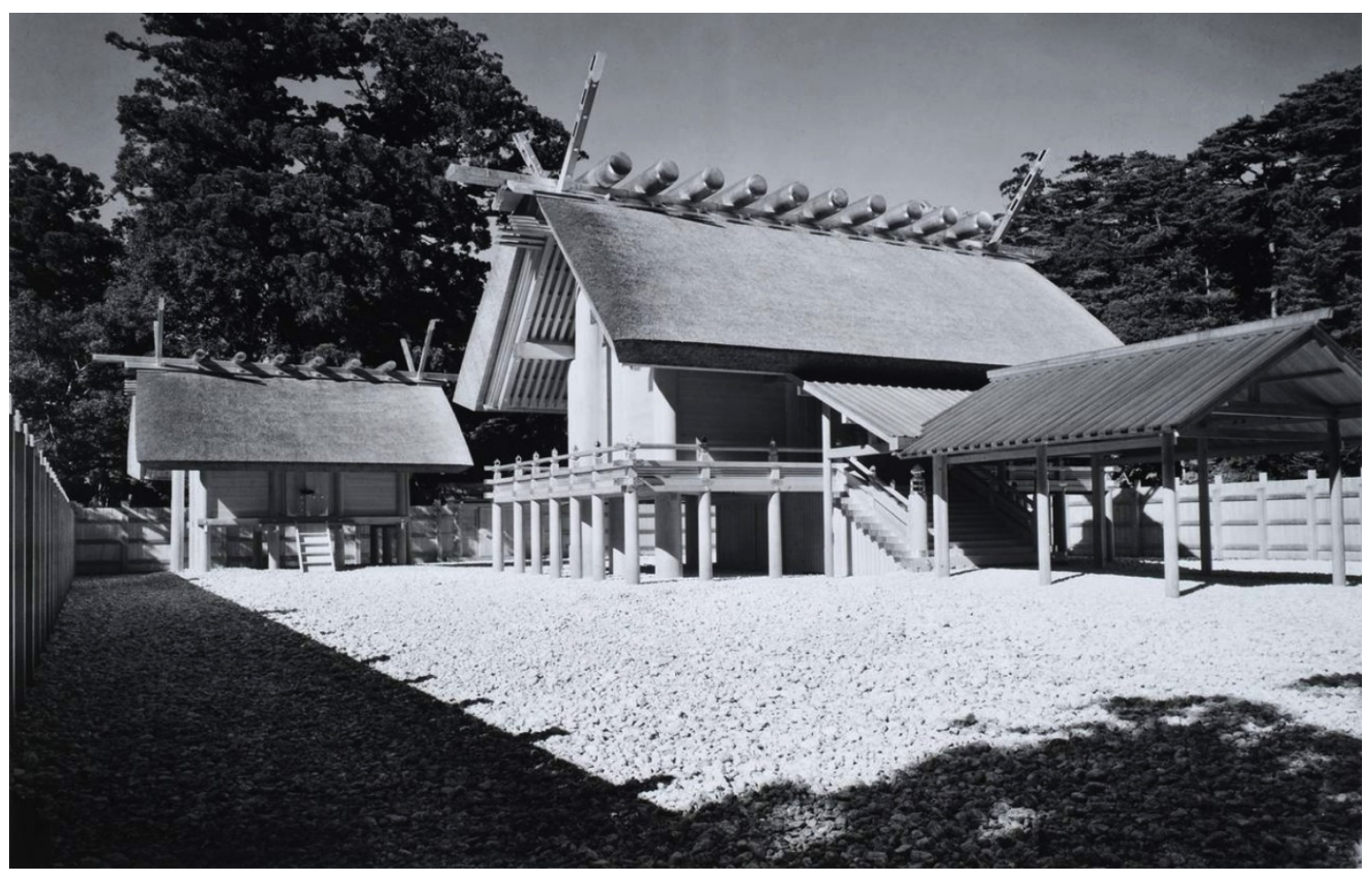

FIG. 6 THE MAIN SANTUARY AND THE WEST TREASURE HOUSE, INNER SHRINE (NAIKU): Watanabe, Yoshio. CCA Collection, Ise Shrine Japan, 1953. 


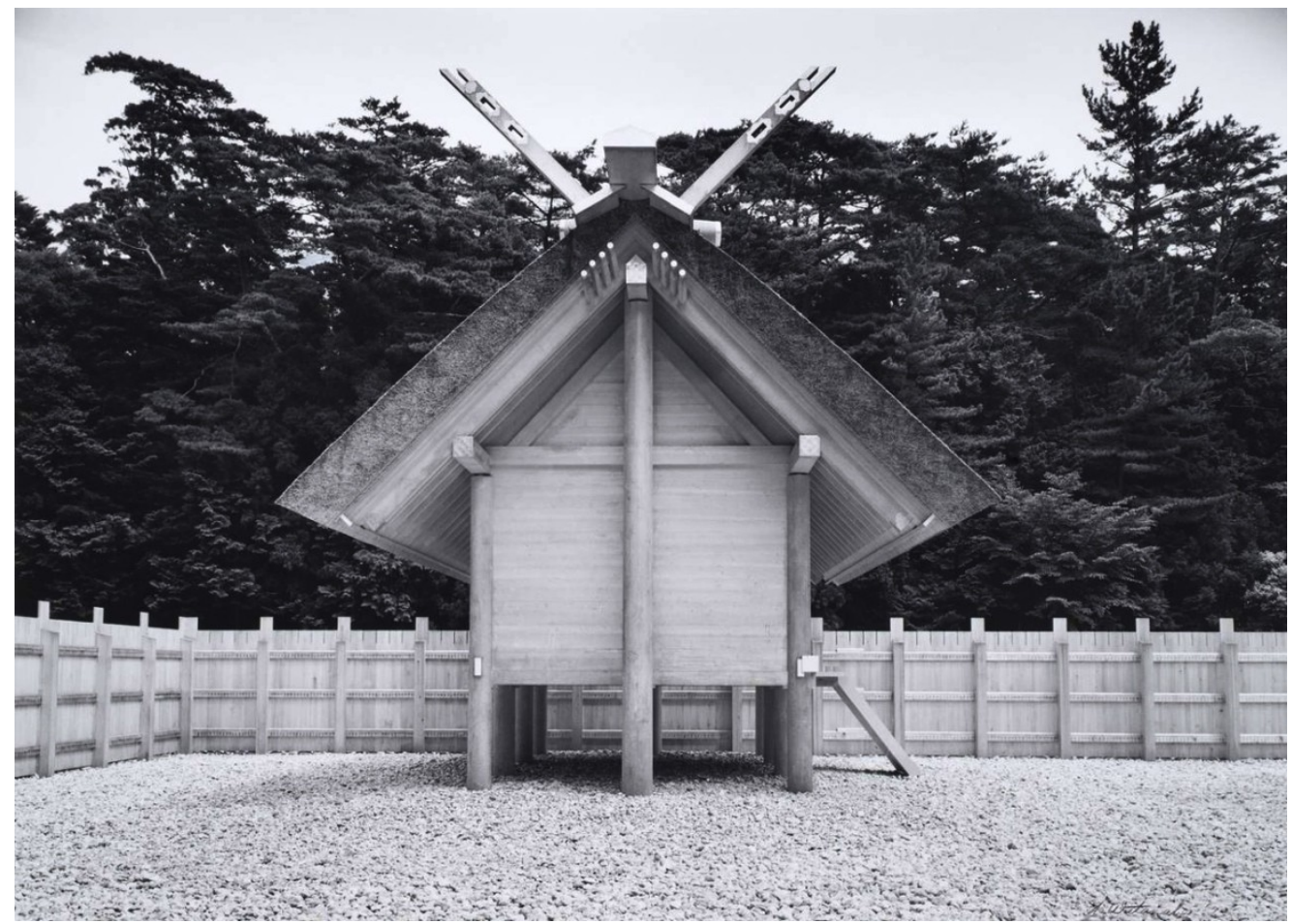

FIG. 7 THE EAST TREASURE HOUSE, INNER SHRINE (NAIKU): Watanabe, Yoshio. CCA Collection, Ise Shrine Japan, 1953.

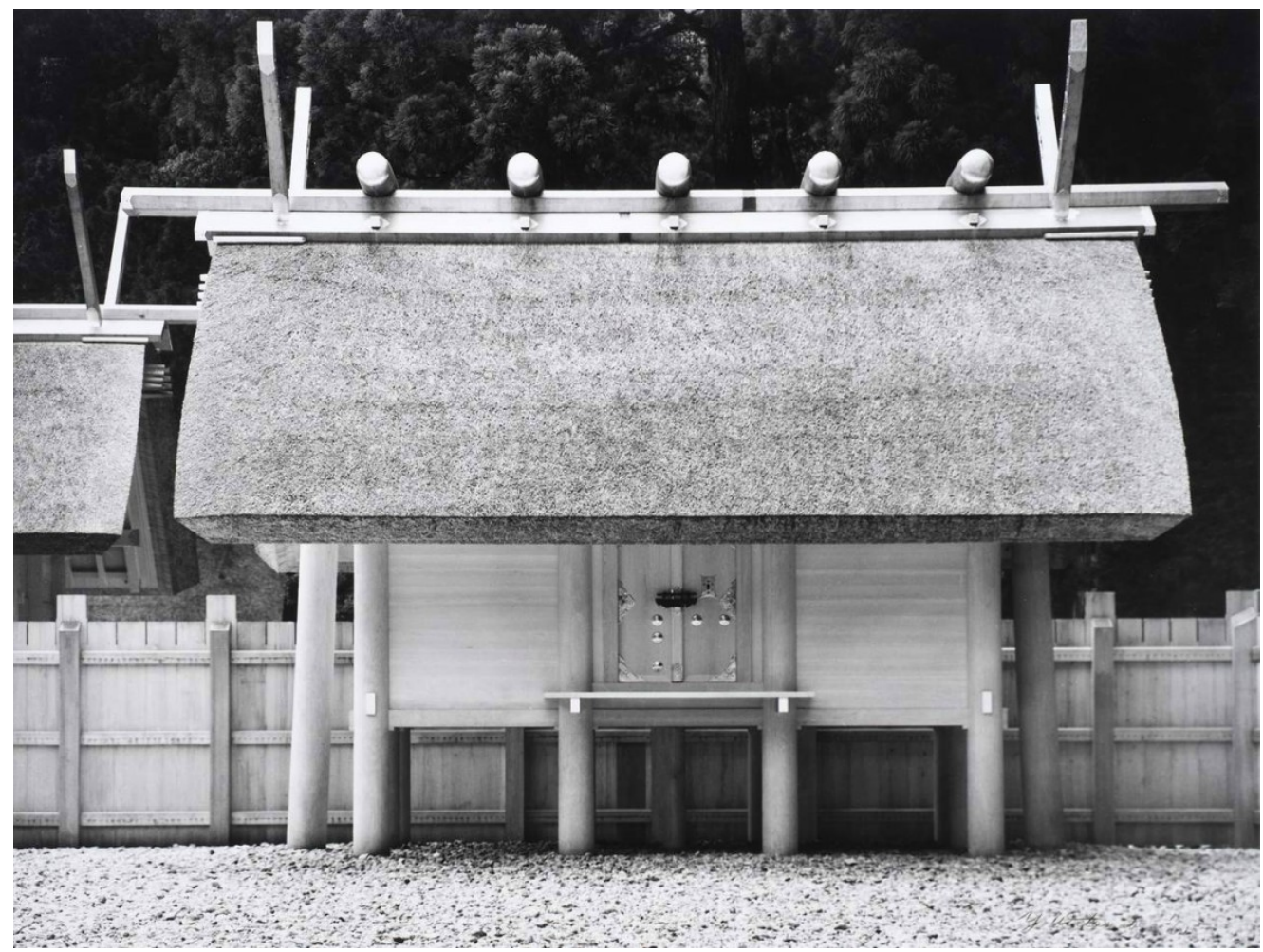

FIG. 8 THE WEST TREASURE HOUSE, OUTER SHRINE (GEKU): Watanabe, Yoshio. CCA Collection, Ise Shrine Japan, 1953. 


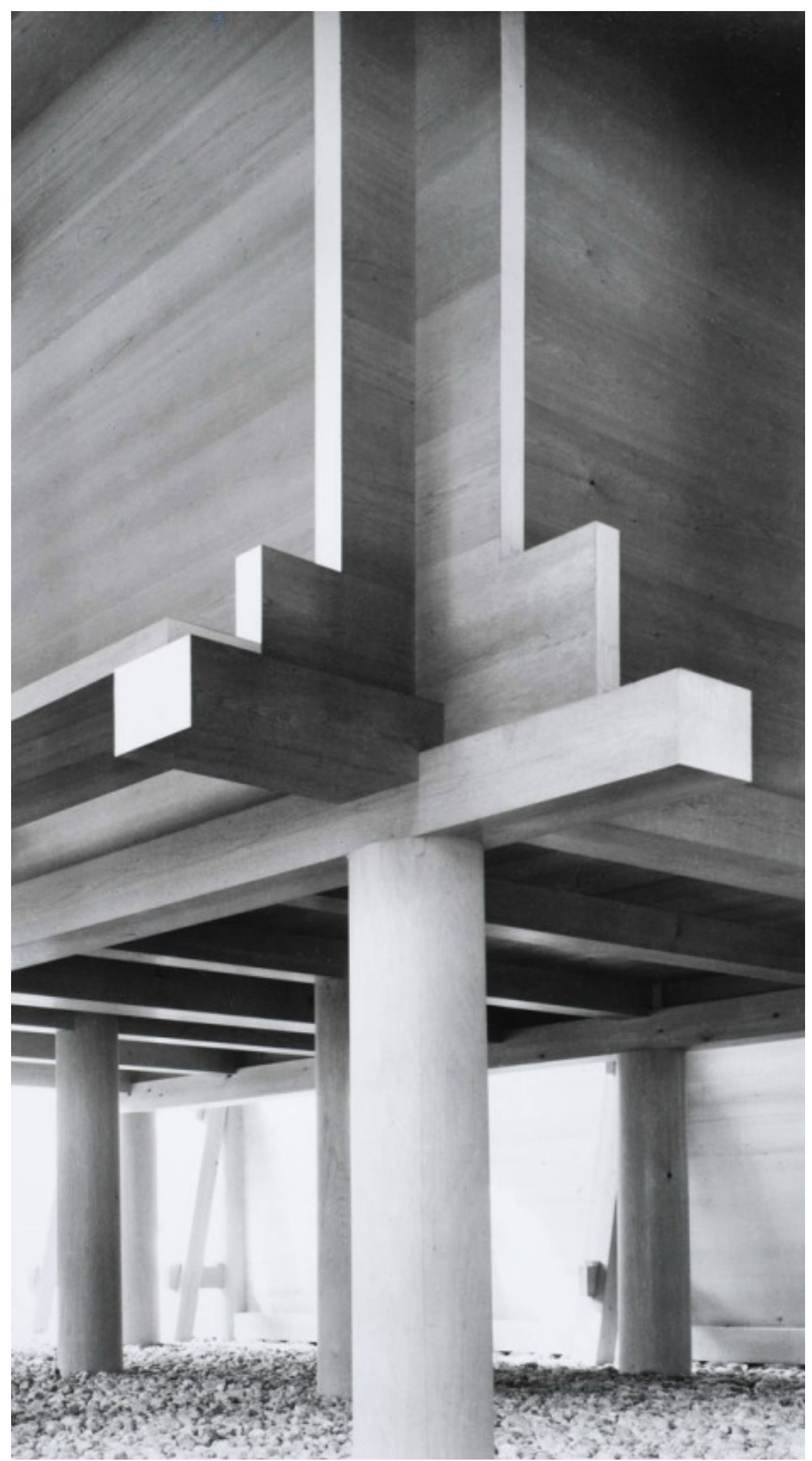

FIG. 9 THE SOUTHEAST CORNER OF THE HALL OF THE DAILY OFFERING, OUTER SHRINE (GEKU): Watanabe, Yoshio. CCA Collection, Ise Shrine Japan, 1953 or 1960. 


\subsubsection{Inter Action Centre}

Cedric Price was a British architect who challenged conventional ideas of architecture by valuing flexibility over form. Acknowledging the unpredictability of the future, Price evolved an anticipatory architecture that he believed would be beneficial to society. ${ }^{47}$ Using the metaphor of food, Price likens architecture to objects that will be consumed and evacuated, ${ }^{48}$ and so a building that is designed for disassembly will be consumed by users and then destroyed once its useful life is over. By anticipating demolition, Price argues that architecture has a limited relevance and that architects who create monumental structures do it for their own glory and not for the benefit of users. ${ }^{49}$ Price was not just an architect, but also a member of the National Institute of Demolition contractors, and he had little respect for heritage structures that no longer had a useful function and could not be adapted. ${ }^{50}$ Unlike planned obsolescence, where products are engineered to fail in order to ensure future demand, Price's vision does not design failure, but he prepares for unforeseen technological advances and social changes that might make his architecture irrelevant and bring about its demise.

Price's Inter Action Centre was designed to respond to the needs of the user, introducing a flexible architecture that was economical, easily constructed, and, most importantly, could be disassembled. The Inter Action Centre resembled a smaller version of Price's most famous design, the Fun Palace, which was never

\footnotetext{
47 Mathews, From Agit-Prop to Free Space. 41.

48 Ibid.

49 Ibid. 200.

50 Ibid.
} 
actually constructed because of governmental red tape..$^{51}$ The Inter Action Centre was completed in 1971 in Kentish Town, an area of northwest London, England.52 Modular spaces were created within an exterior steel frame structure, and components could be relocated within these spaces through the use of cranes that traveled along the structure. The components were mostly in the form of long steel boxes that could be slotted into the steel frame. The Centre could therefore be adapted for new activities on site with relative ease. The building functioned as a community centre until it was demolished in $2000 .{ }^{53}$ By this point, the building had entered a period of disuse and had become a drain on the local economy, and instead of siding with the preservationists, who lobbied for the Inter Action Centre to receive heritage designation, Price demanded that it be torn down and even produced documents to guide the demolition process, including information about how materials could be recycled. ${ }^{54}$ Price argued that monumental architecture only had a place in a culture that was itself monumental, 55 implying that he believed that our modern culture is instead transient.

Price was reacting against the abundance of heritage-designated Victorian architecture in London at the time. By contrast, the buildings that Price designed would only occupy the landscape for as long as they were appropriate for the culture. His writings clearly indicate his designs intentions to have his architecture demolished when the time was appropriate. The mostly steel materiality of Inter

\footnotetext{
51 Ibid.

52 Ibid.

${ }^{53}$ Ibid.

${ }^{54}$ Ibid.

$55 \mathrm{Ibid}$.
} 
Action Centre made disassembly more financially viable as scrap metal is a valuable commodity. The simple form of the design and modular dimensions meant that components would be easy to reuse in various applications. While the Inter Action Centre itself was demolished, its physical parts endure in new forms.

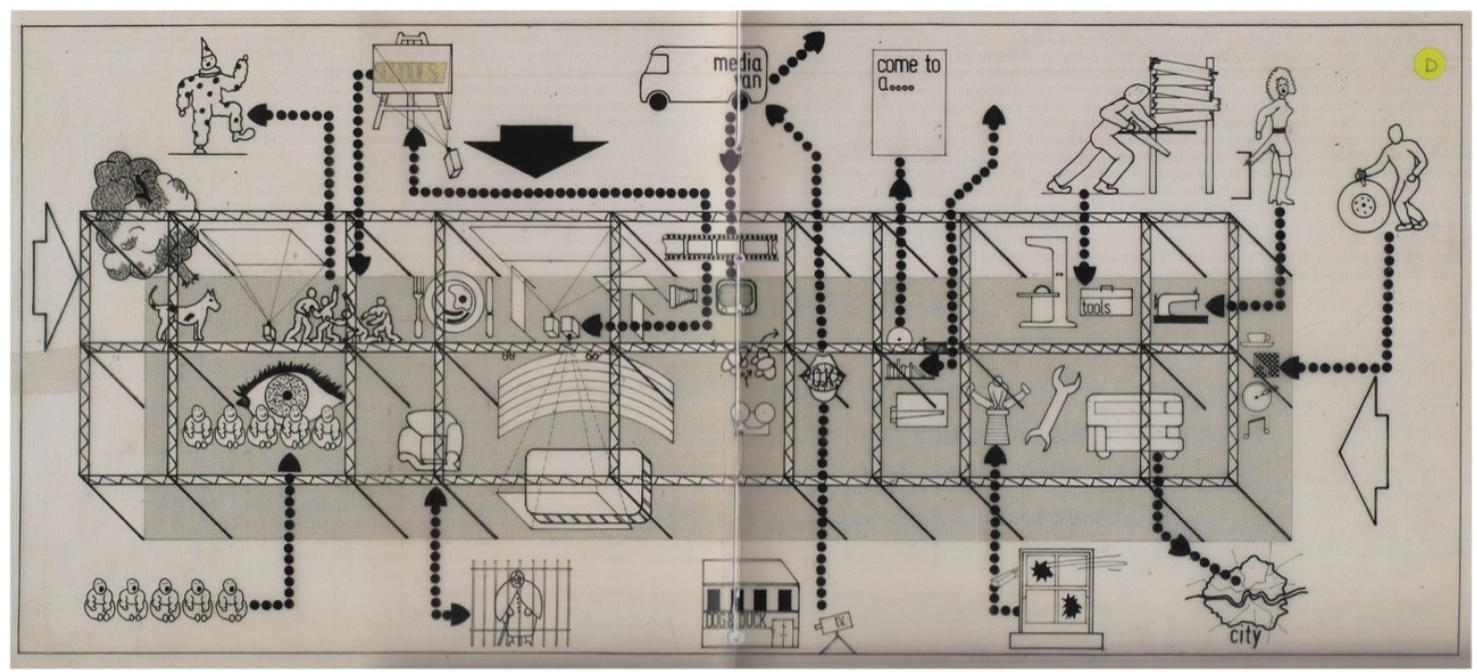

FIG. 10 DIAGRAM OF VARIOUS COMMUNITY FUNCTIONS FUN PALACE: Price, Cedric. From Agit-Prop to Free Space.1961. 


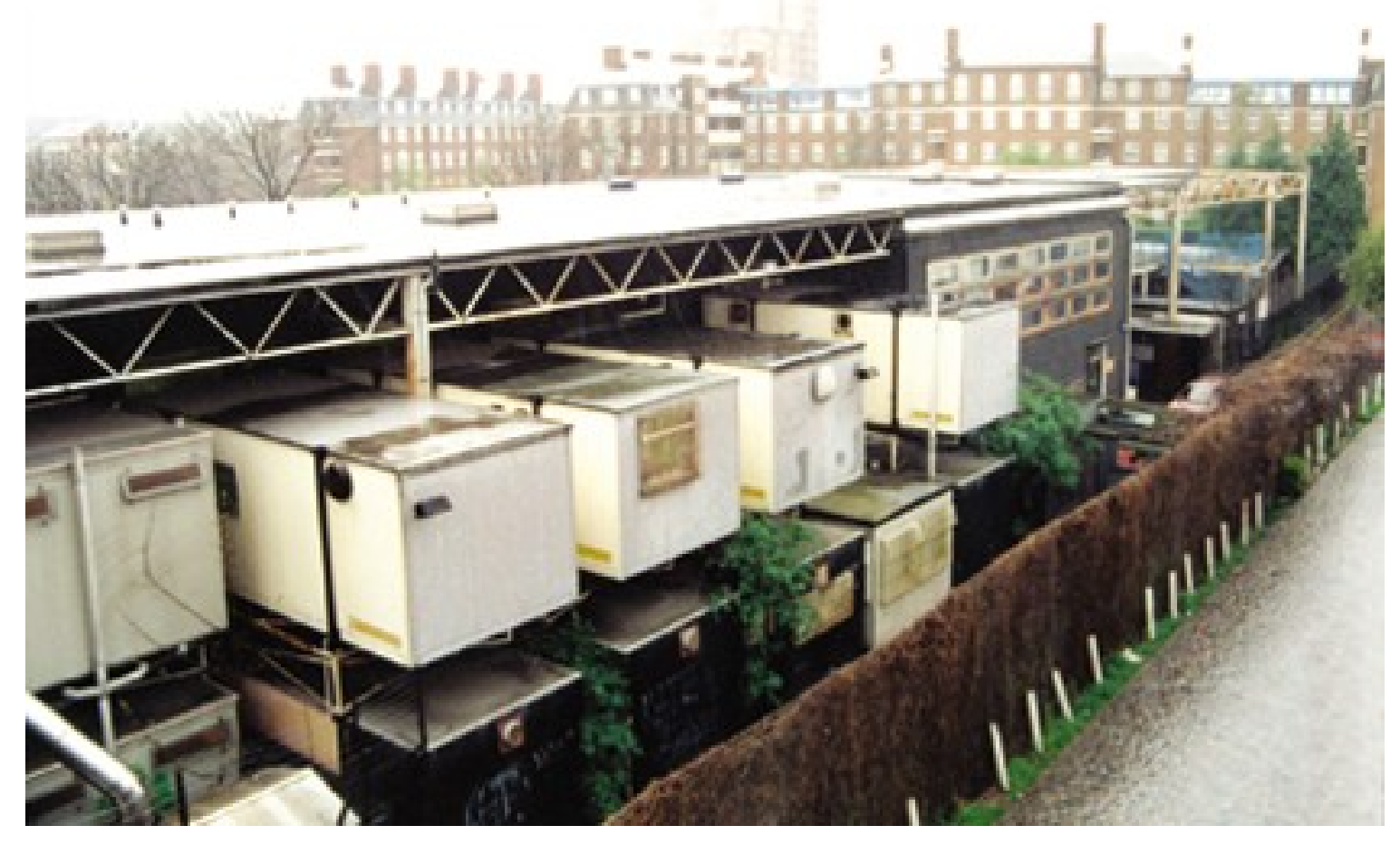

FIG. 11 INTER ACTION CENTRE: Mathews, Stanley. 1977.

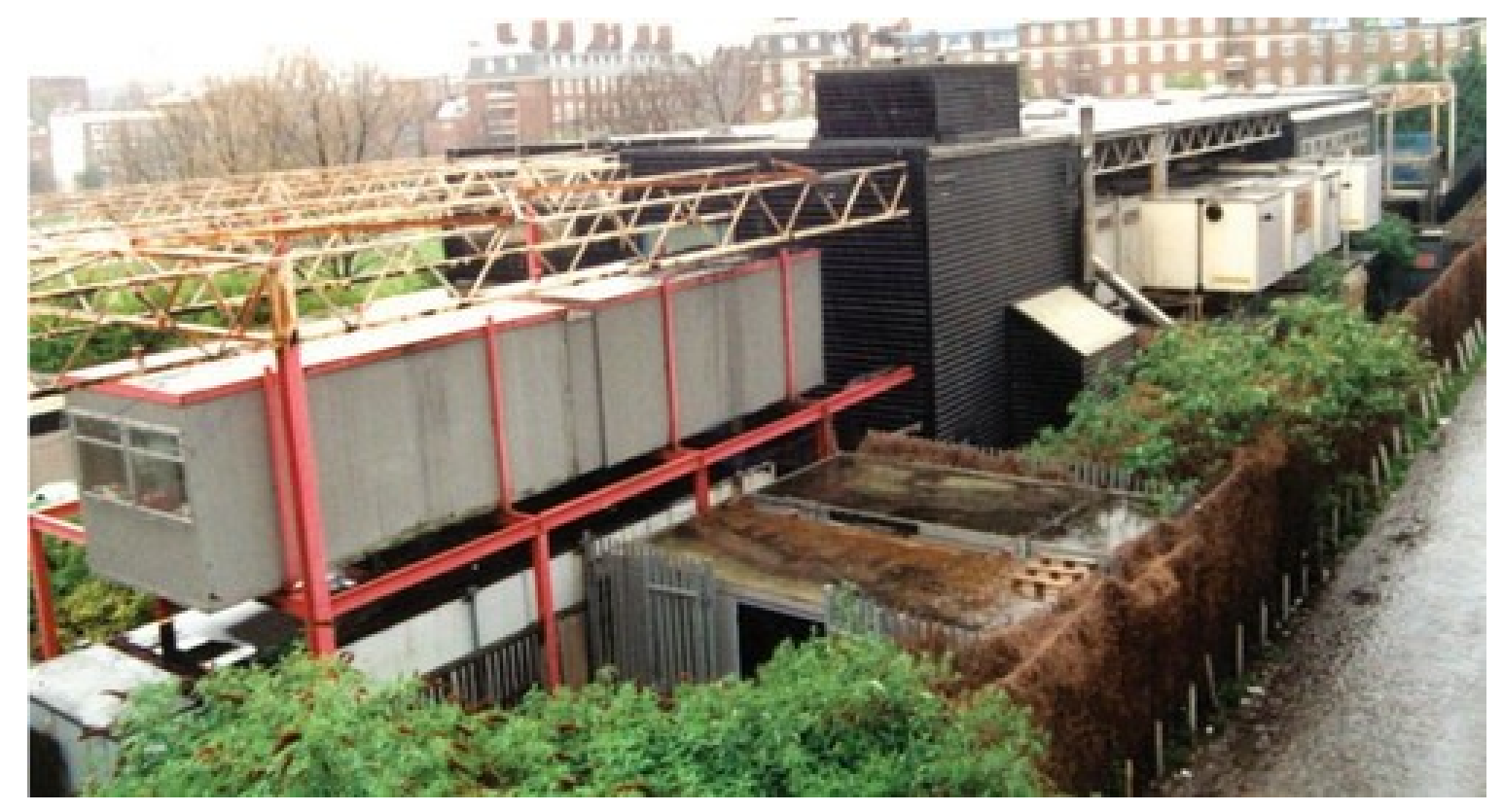

FIG. 12 INTER ACTION CENTRE: Mathews, Stanley. 1977. 


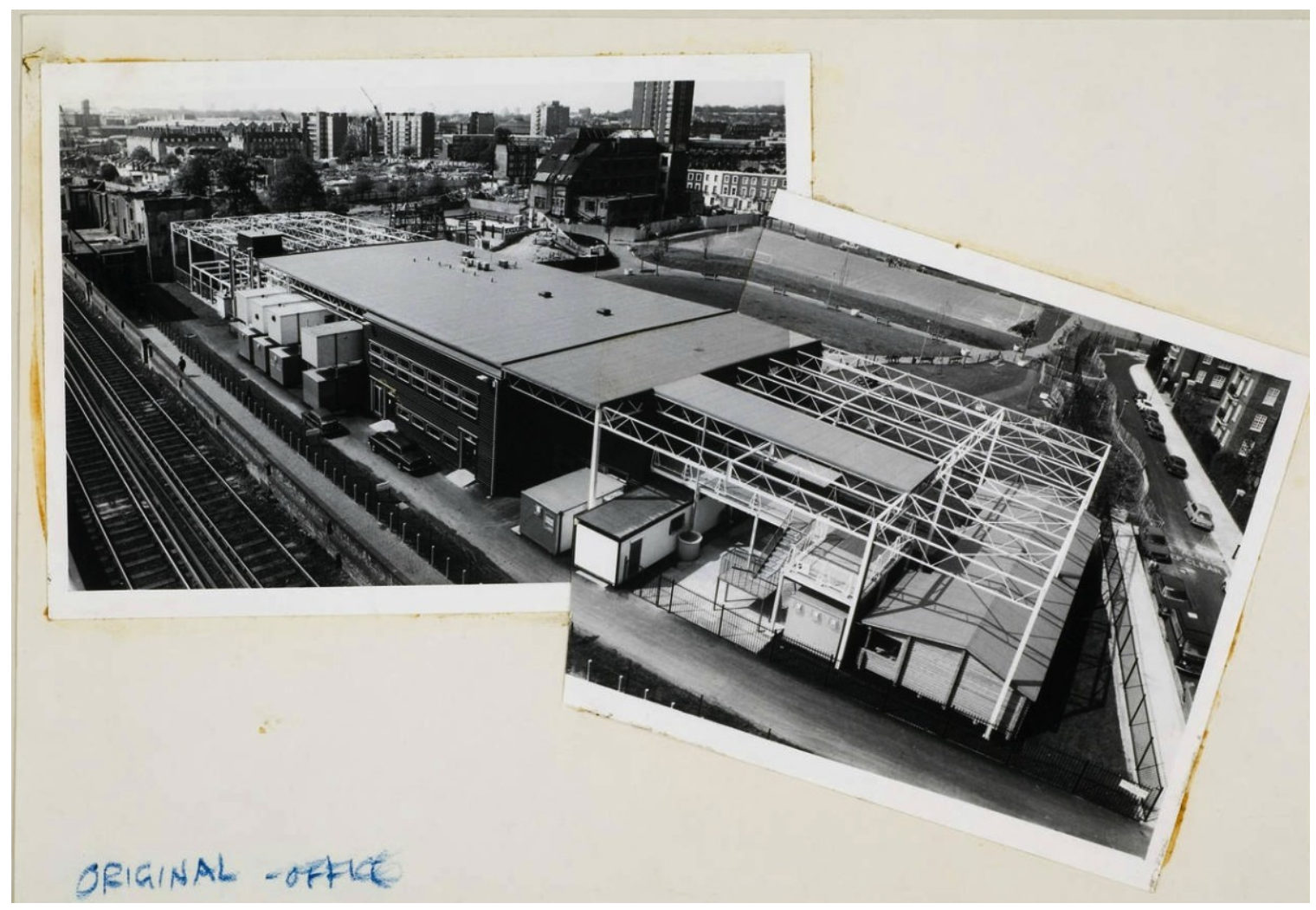

FIG. 13 INTER ACTION COMMUNITY ARTS CENTRE: AERIAL VIEW: Cedric Price Fonds. CCA Collection. 19701981.

\subsubsection{Les Grandes Tables de L'île Seguin}

The Paris firm, 1024 Architecture, built Les Grandes Tables restaurant on the Île Seguin in 2011, knowing that it would be displaced just two years after its completion. The Île Seguin is located on a river between two suburbs west of Paris, Boulogne-Billancourt and Sèvres. The Renault automobile company built its factory on the island between 1929 and 1934 and operated a large production line there until $1992 .^{56}$ Abandoned for thirteen years, the factory was finally demolished in

\footnotetext{
${ }^{56}$ Mariabruna Fabrizi, "A Building is an Island is a Building: The Île Seguin Renault Factory in Paris," SOCKS website, December 29, 2013, http://socks-studio.com/2013/12/29/a-building-is-an-islandis-a-building-the-ile-seguin-renault-factory-in-paris.
} 
$2005 .{ }^{57}$ Some members of the public were outraged by the demolition, including Pritzker prize-winning architect Jean Nouvel, preferring the factory to be awarded heritage status as a significant industrial site. ${ }^{58}$ In 2009 it was announced that Jean Nouvel would become the coordinator of a project to turn the island into a center for contemporary art. ${ }^{59}$ In the interim, in the interest of maintaining public interest and activity on the island, the architects at 1024 Architecture created a temporary restaurant that could be easily dismantled. A rectangular wooden box that houses the café is wrapped by a lightweight scaffolding structure which lifts the cafe off the ground, creating an open space below which could be utilized for informal gatherings. Shipping containers border the side of the structure, providing an elevator and housing other mechanical and electrical services. The interior panels have visible connections that create a strong grid-like pattern on the walls, complementing the aesthetic of exposed structure, straight lines, and simple rhythms. The form is reminiscent of traditional industrial buildings with a long hall and peaked roof, recalling the industrial history of the site.

As a temporary structure, Les Grandes Tables realizes many principles of Design for Disassembly. The materials chosen for this project truly embody the idea of reusability. The scaffolding and the shipping containers are common, standardized components that are easily utilized for other structures and purposes. The raw finish of the metal and simple design of the structure should find a highly lucrative aftermarket for the scaffolding, as the parts can easily be reassembled into

\footnotetext{
${ }^{57}$ Lizzy Davies, "Life after Renault: Ile Seguin to Become Paris Culture Hub," The Guardian, July 9 , 2009, www.guardian.co.uk.

58 Ibid.

${ }^{59}$ Ibid.
} 
many conventional forms. The exposed connections and independence of elements should allow for simple disassembly, leaving materials intact and undamaged.

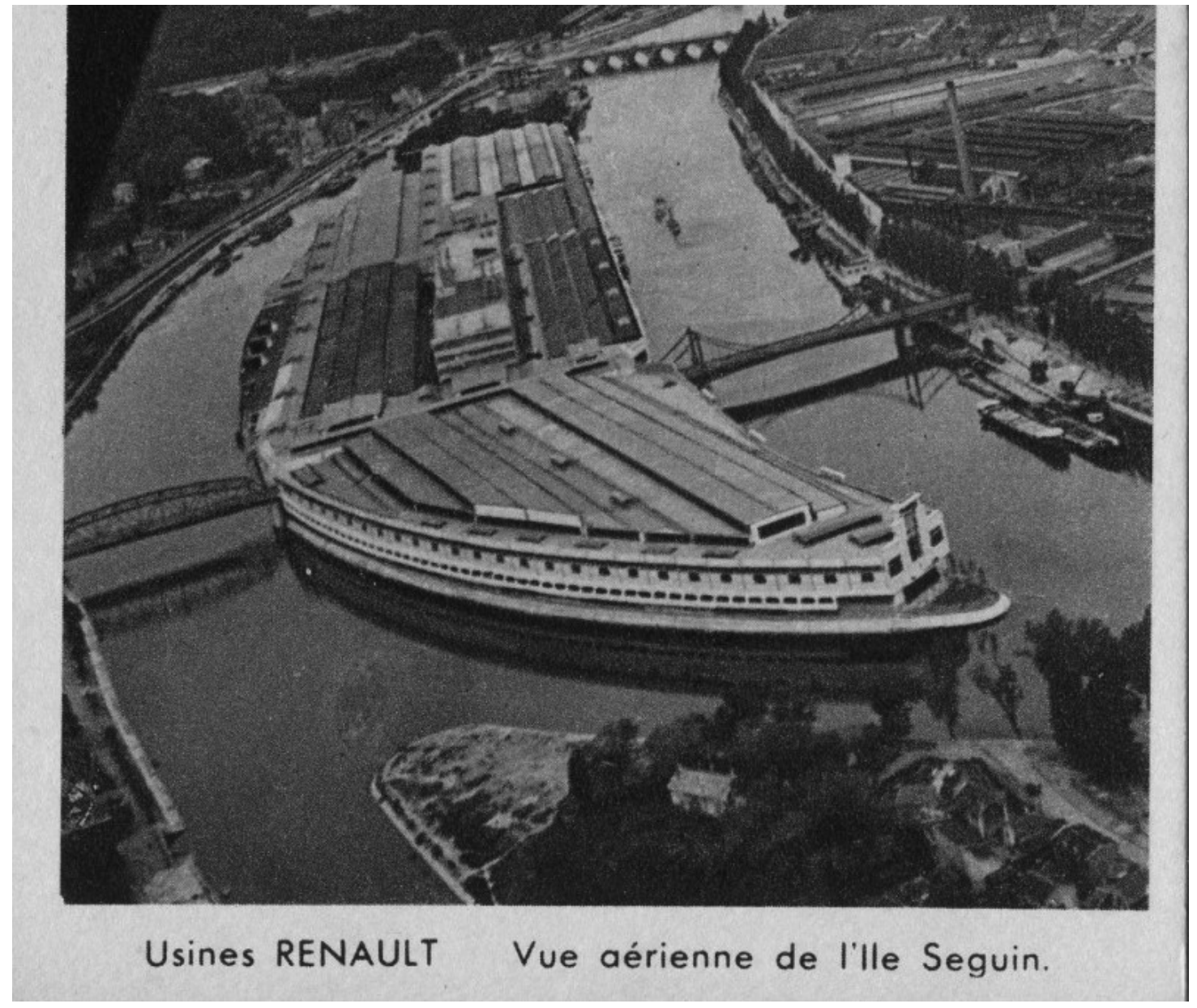

FIG. 14 AERIAL VIEW OF SEQUIN ISLAND: Doisneau, Robert. Gamma-Rapho Collection via Getty Images. Paris, France. 1935 


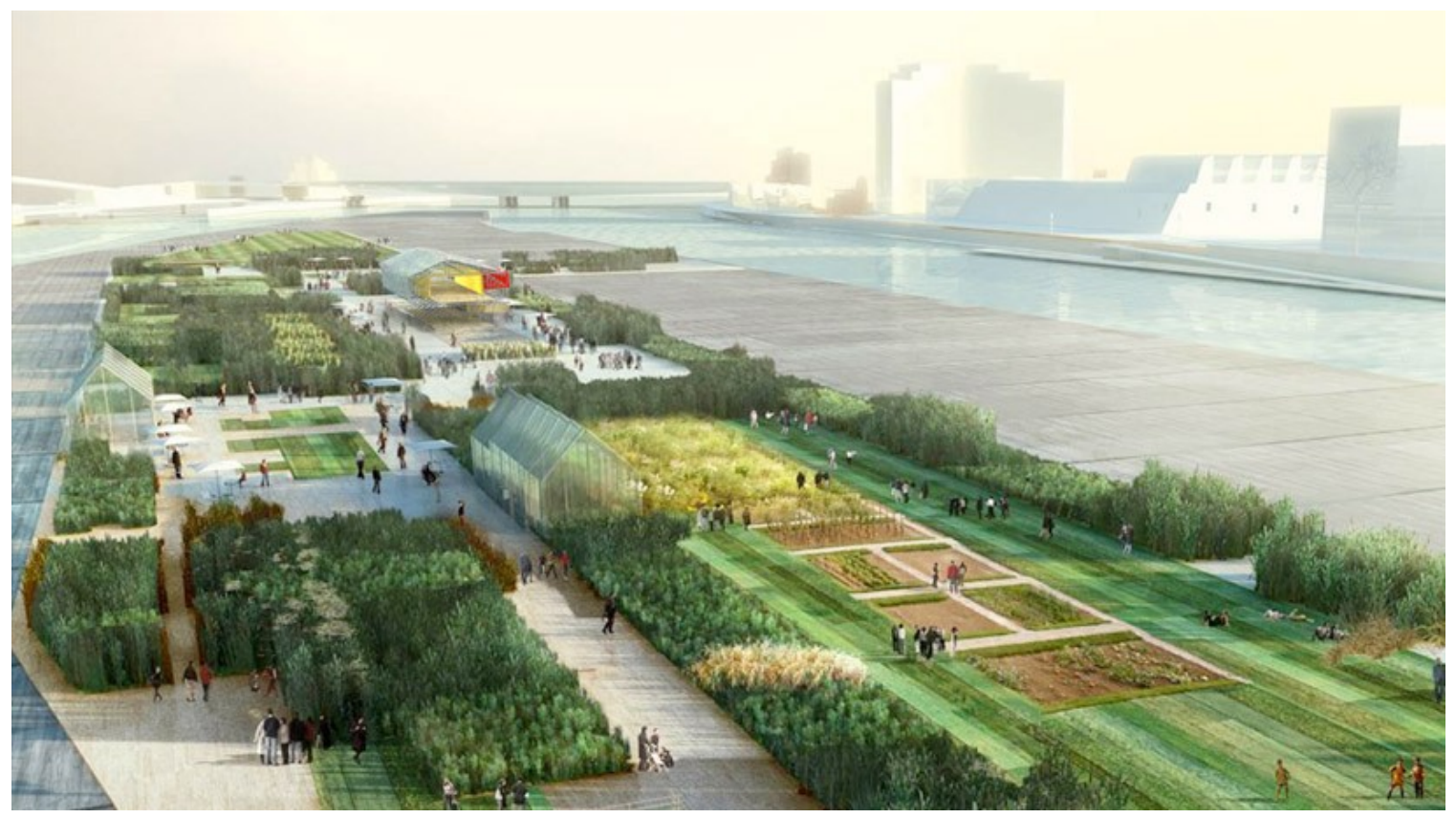

FIG. 15 AERIAL DESIGN OF ILE SEGUIN: 1024 Architecture, 2011.

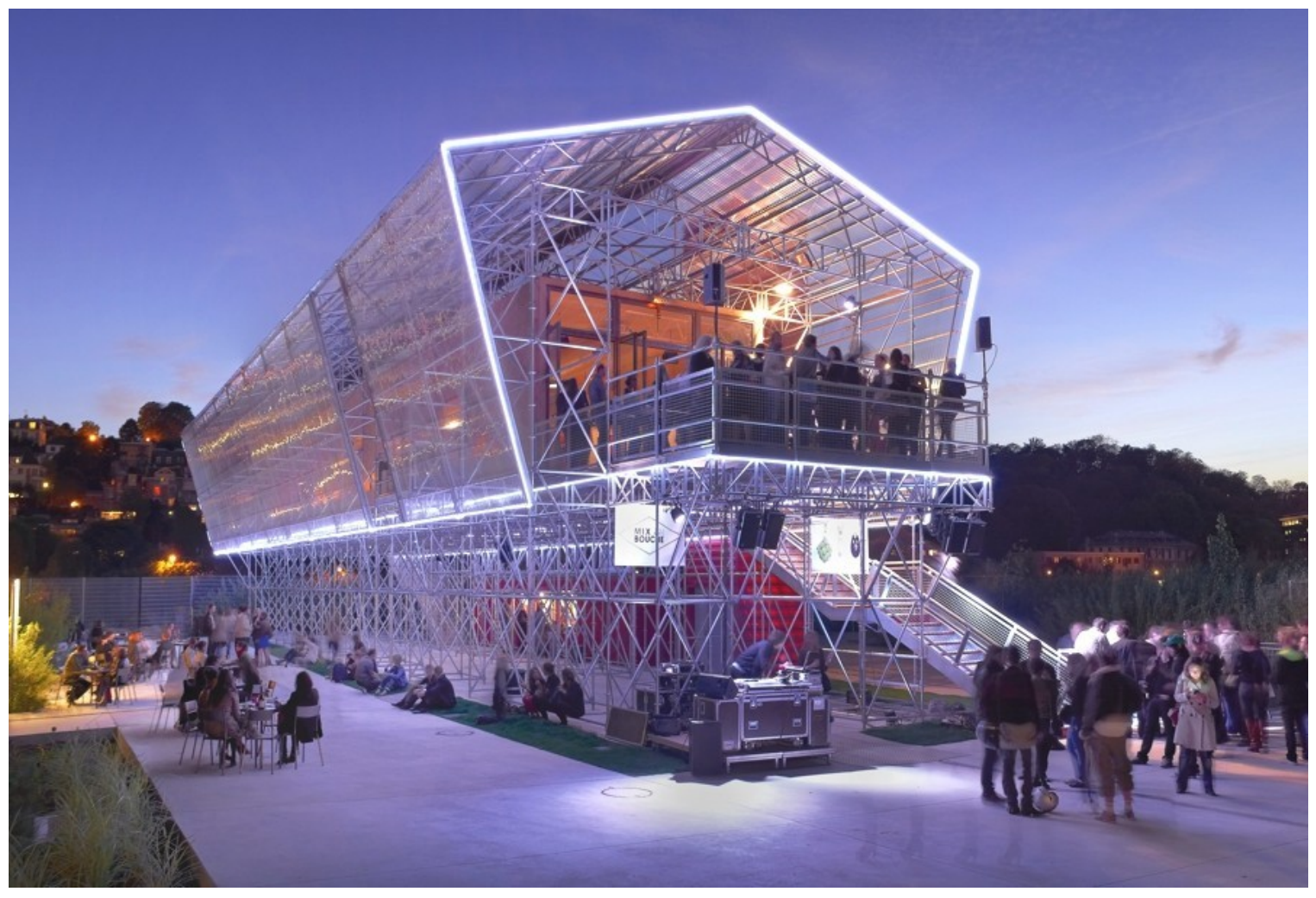

FIG. 16 LES GRANDES TABLES DE L”ILE SEGUIN EXTERIOR: Pelleschi, Brice. 1024 Architecture, 2011. 


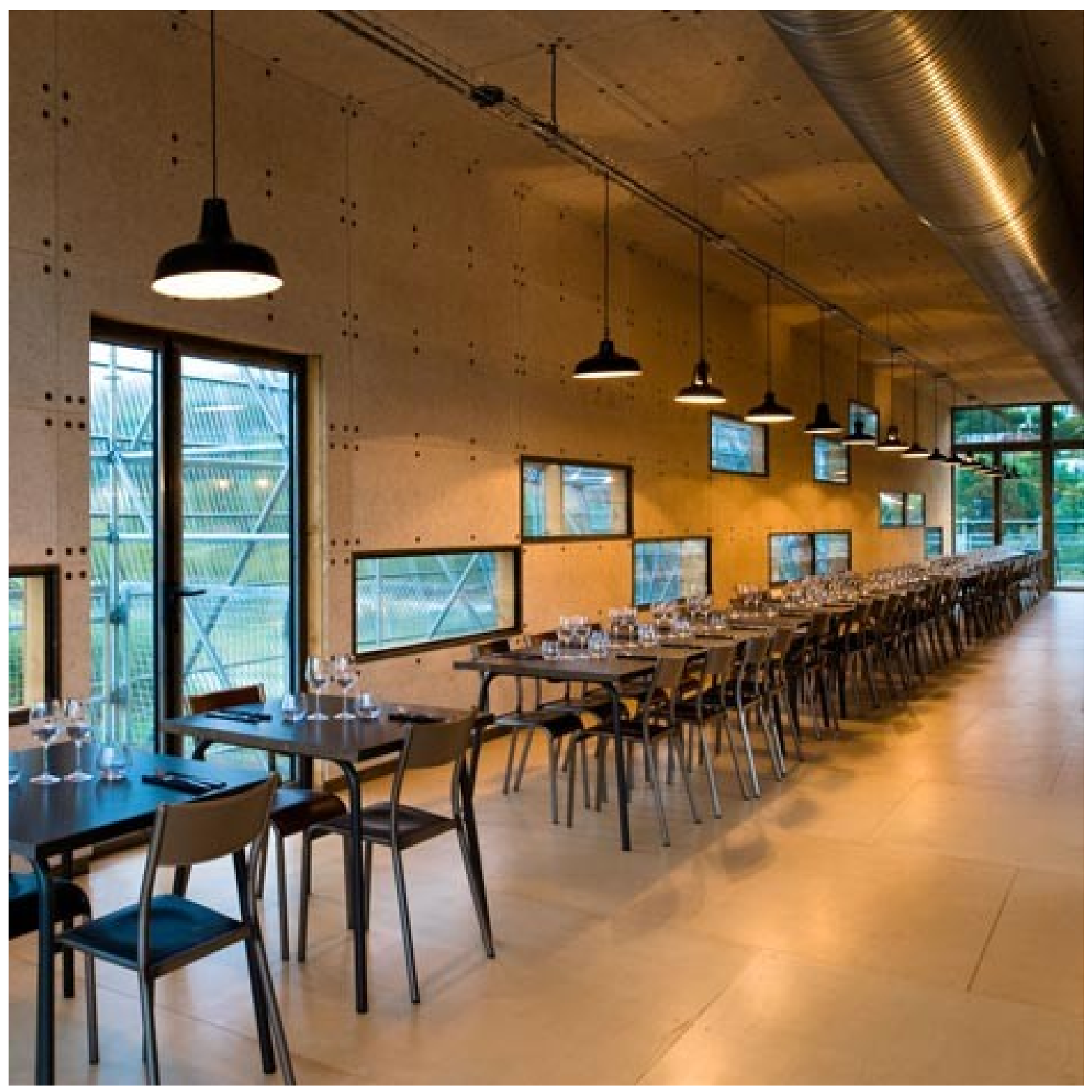

FIG. 17 LES GRANDES TABLES DE L"ILE SEGUIN INTERIOR: Sancereau, C. 1024 Architecture, 2011.

\subsubsection{Summary}

The cyclical remaking of the Ise Shrine is a sacred tradition passed down through generations as a way of preserving craft traditions. The sacred unmaking is just as important as the remaking of the shrine. If this concept were applied to contemporary construction, then creation would be taught through the disassembly 
of parts, fostering an appreciation for productive demolition and cultivating wisdom in the construction industry. The model of the Inter Action Centre demonstrates unmaking as a community endeavor, performed according to need. And Les Grandes Tables presents unmaking as succession, submitting its parts to dissemination in new forms and relinquishing the site to new development.

Through reconstruction, the Ise Shrine creates a brand new shrine, preserving the forms of the past supported by the introduction of new elements, like the Suyane that protects the shrine's rebuilding. These new elements work to revive the past through ritual, facilitating the rebirth of old traditions, techniques, and forms. In contemporary applications, recuperative additions can activate the existing urban fabric, making sense of the old and bringing new life to depressed areas. Cedric Price regarded the stagnant urban climate of London with disdain, yearning for space within the tightly controlled urban fabric to explore new forms that could animate a community through cultural recreation. The resurrected industrial form of Les Grandes Tables, realized in the present through the use of new materials but preserving the memory of the Renault Factory and its historical significance, keeps the area active during a transition period. 


\section{Chapter Four: Detroit}

"Detroit is many cities today, a place of thriving neighborhoods yet abysmal abandonment; a city of highly educated professionals that is filled with illiterate dropouts; a city of soaring achievement in medicine, the arts, and industry, yet a city that is paradoxically presents the most dispiriting vistas in urban America." John Gallagher, 2013

Detroit is a city in demolition. No North American city has had to face such devastating population loss, falling from 1.8 million people in 1950 to just over 700,000 in 2013.60 Since photographs of derelict houses make attractive lures for readers, the media has been enamoured with the city's tragic story of bankruptcy and decay, which has been depicted from every angle. The data clearly shows that Detroit is a city in a period of demolition; FIG. 18 and FIG. 19. Infographs provided by Data Driven Detroit show permits approved for construction and permits issued for demolition. Clearly, demolition heavily outweighs development. Detroit is thus a model of an urban climate in the process of disassembly. ${ }^{61}$

60 U.S. Census of Population and Housing, 1990. Statistical Table 46 Population Rank of Incorporated Places of 100,000 Population or More, 1990; Population, 1790 to 1990; Housing Units: 1940 to 1990. U.S. Department of Commerce, 1990.

${ }^{61}$ I am grateful to my thesis advisor, Janine Debanne, who resided in Detroit and taught at the University of Detroit Mercy School and Architecture from January 1995 to 2001 for sharing her insights about Detroit. 


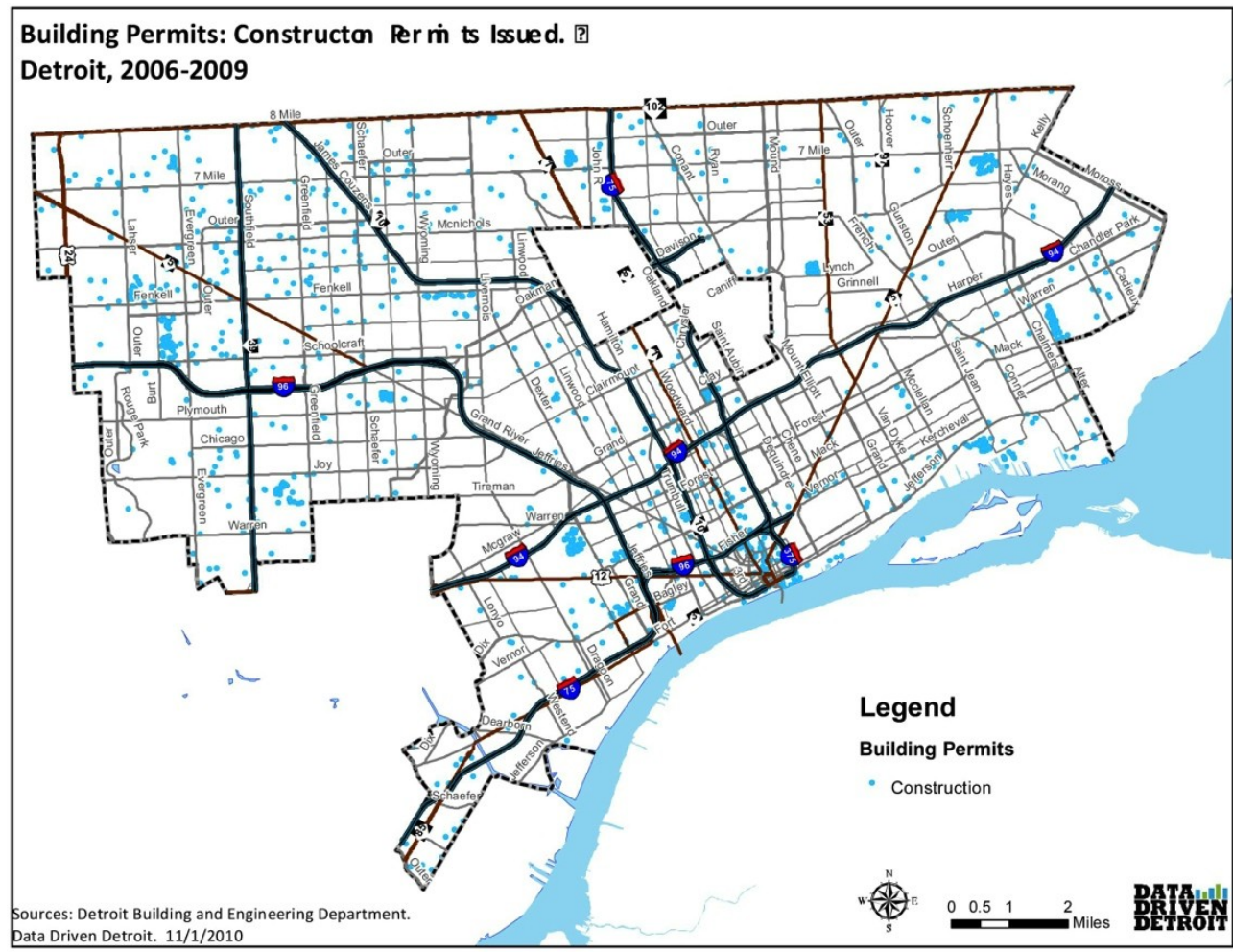

FIG. 18 CONSTRUCTION PERMITS ISSUED, DETROIT 2006 - 2009: Data Driven Detroit, 2010. Accessed November 2013. <http://datadrivendetroit.org/>.

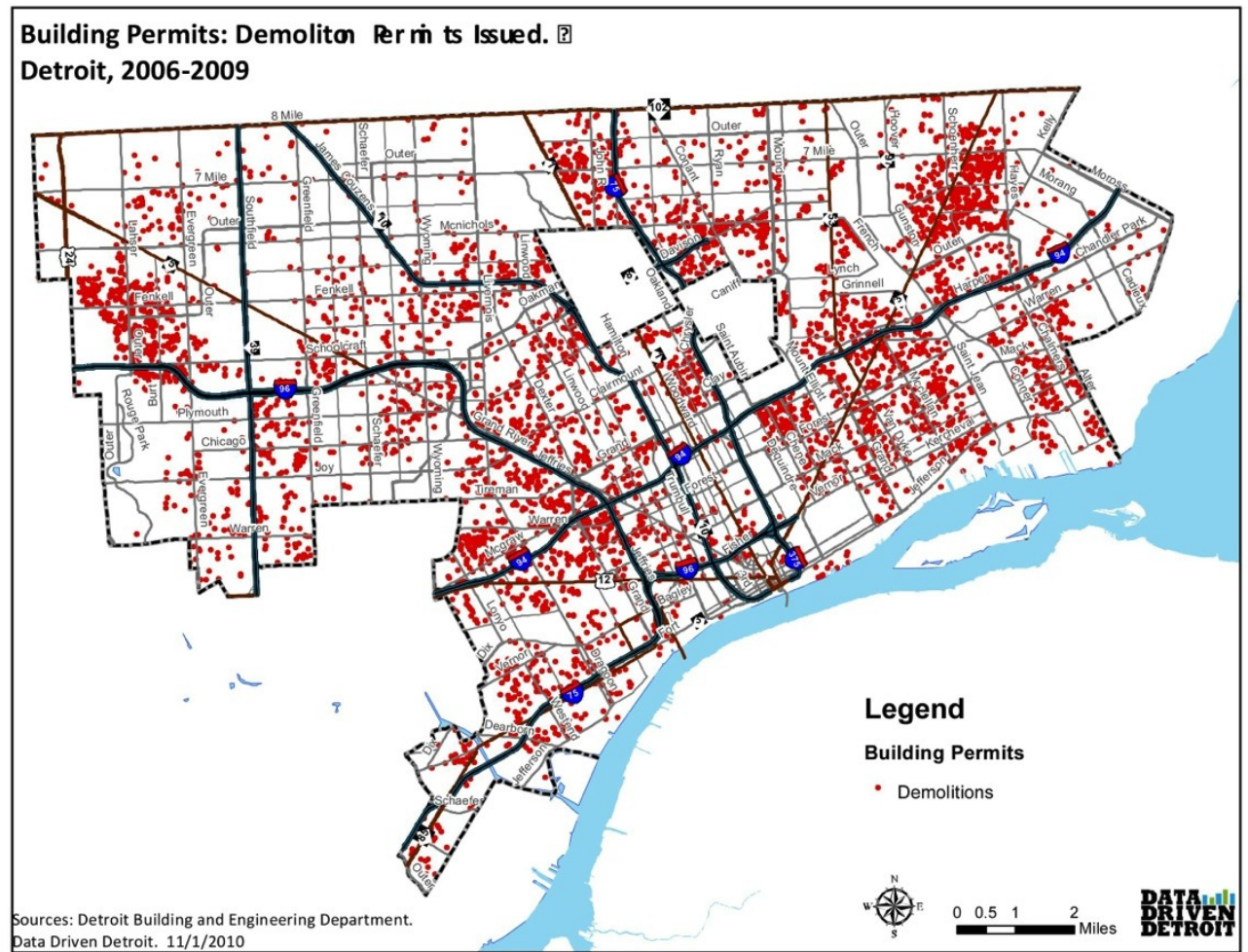

FIG. 19 DEMOLITION PERMITS ISSUED, DETROIT 2006 - 2009: Data Driven Detroit, 2010. Accessed November 2013. <http://datadrivendetroit.org/>. 


\subsubsection{History and Current Climate}

Historically dominated by a strong automotive industry, Detroit is commonly known as the Motor City. Its location along the Great Lakes Waterways, connecting this Midwestern American city to other strong ports, has determined its history. Founded by French explorer Antoine Laumet de Lamothe Cadillac, Detroit became an important port for the fur trading industry, and its strong economy accommodated entrepreneurs and created new markets. ${ }^{62}$ One such entrepreneur, Henry Ford, created the first automobile factory in 1913 and his success encouraged other automobile pioneers to establish their base in Detroit also. ${ }^{63} \mathrm{~A}$ strong labour force was necessary to support these factories and Detroit quickly became a boom city.

As is typical of port cities, Detroit's downtown developed around the waterfront. A large fire in 1805 cleared the city's core and prompted a rebuilding period. Augustus B. Woodward drew up new plans for the city using a radial form, fashioned after the designs of Washington, D.C., where Woodward had worked for many years. ${ }^{64}$ The plan provided large lots, establishing Detroit's disposition to single-family homes and sparsely populated neighbourhoods. ${ }^{65}$ Although Detroit never implemented the full extent of Woodward's radial plan (FIG. 20), adopting the more familiar checkerboard pattern, his effect on the downtown core still remains intact.

\footnotetext{
${ }^{62}$ Arthur M. Woodford, This is Detroit, 1701-2001 (Detroit: Wayne State University Press, 2001). 20. 63 Ibid. 96.

${ }^{64}$ Detroit (Mich.). City Plan Commission. Preliminary Plan of Detroit. Detroit: City Plan and Improvement Commission, 1916.

${ }^{65}$ Woodford, This is Detroit. 39.
} 
Drastic changes to the fabric of the city resulted from slum clearance of the neighbourhood Black Bottom, in 1946, and from highways construction. ${ }^{66}$ The area of Black Bottom remained vacant for ten years before Lafayette Park was built. The residential district of Lafayette Park, Detroit, located just to the north of the site, was the first urban renewal project in the United States, and was designed by architect Ludwig Mies van der Rohe, urban planner Ludwig Hilberseimer, and landscape architect Alfred Caldwell. ${ }^{67}$ This modern residential neighbourhood provided suburban living qualities like open spaces and planting in a high-density neighbourhood. ${ }^{68}$ The highways displaced 1000 of buildings in Detroit, completely rearranging the economic conditions of the neighbourhoods surrounding them. One highway, the Lodge Freeway, now known as the M-10, resulted in the destruction of 2,222 buildings and a total of " 423 residences, 109 businesses, 22 manufacturing plants, and 93 vacant lots had been condemned for the first three mile stretch."69 Evident within the comparisons of the aerial imagery of 1949 (FIG. 21) and 1961, (FIG. 22) the 1950's was a period of extensive transformation and development for Detroit, securing Detroit's place as one of the great American cities.

Changes in industrial shipping patterns also changed the downtown core. Beginning in 1836, Pontiac Railroad had constructed a rail line that cut through the city on a street known as Dequindre, heading south to the waterfront and

${ }^{66}$ Jeremy Williams, Detroit: The Black Bottom Community (Charleston, SC: Arcadia Pub., 2009). 10.

67 Janine Debanne, "Claiming Lafayette Park as Public Housing," in CASE-- Hilberseimer/Mies van der Rohe, Lafayette Park Detroit, ed. Charles Waldheim.. (Munich: Prestel, 2004), 67-80.

${ }^{68}$ Janine Debanne, "Remembering the Towers," in Thanks for the View, Mr. Mies: Lafayette Park, Detroit, ed. Danielle Aubert et al. (New York, NY: Metropolis Books, 2012)

${ }^{69}$ Ibid. 10. 
connecting industries based there to a large transportation network..$^{70}$ The Grand Trunk Western Railroad took over the line in 1882 and sunk the tracks below grade when booming business demanded a clear path for vehicle traffic. ${ }^{71}$ As the automobile industry grew, however, industrial centers shifted to the outer limits of the city. Large shipping yards necessary for high volumes of products were just not feasible in the long-established fabric of the waterfront, and across North America, industry abandoned their waterfronts. The Grand Trunk Western train line continued to operate as a commuter rail line until 1983, when it was ultimately abandoned altogether. ${ }^{72}$ For years the former tracks acted as a void in the city, harboring vagrants and miscreants, but recently the site has been rejuvenated as a recreation trail known as the Dequindre Cut.

Detroit's economic success and the influx of population in the 1920's created a need for vast amounts of housing. ${ }^{73}$ With an abundance of habitable land and a population of prosperous citizens, large lots with single-family homes could be produced in extensive quantities. Population density in these new areas was extremely low, but car culture was on the rise, and low density was not seen as a problem. Now, however, it compounds the problems of population loss: with a shrunken tax base, the city cannot possibly provide services to so vast a region. A well-known illustration (FIG. 23) created by Dan Pitera at the University of Detroit Mercy in 2010 demonstrates how three major cities, Boston, San Francisco, and

\footnotetext{
70 George B. Catlin, “The Story of Detroit,” The Detroit News, 1923.

71 "The Dequindre Cut: Two centuries of Transformation \& More to Come," Pure Detroit website, October 17, 2103, http://www.puredetroit.com/index.php/history/the-dequindre-cut-twocenturies-of-transformation-292.html.

72 Ibid.

${ }^{73}$ Woodford, This is Detroit.
} 
Manhattan, could all fit within Detroit's city limits. The population of these three cities combined exceeds three million people. With its current population of just over 700,000, Detroit cannot generate sufficient taxes to support a city the size Boston, San Francisco, and Manhattan combined.

Just outside the city limits, however, wealthy municipalities feed off the perks of proximity to a major metropolis without the obligation to pay the taxes that living in a major metropolis requires. The boundary lines of the city are shockingly apparent: the absence of streetlights, poorly maintained streets, and ruins mark the division between the city and the pristine neighbourhoods of adjacent communities. For instance, Bloomfield Hills, only a half-hour commute from Detroit's city center, consistently ranks in the top five richest communities of over 1000 households per capita in America. ${ }^{74}$ Large highways, like Highway M-10, that cut directly into Detroit's city core encourage people to commute to work and raise their children in a suburban environment away from the apparent crime and pollution of the major metropolis. A suburban exodus struck many American cities in the 1960's and 1970's, with even cities like New York facing bankruptcy in 1975, in part due to the loss of the middle class. ${ }^{75}$ In Detroit's case, suburban exodus combined with the dependence on the auto industry made that industry's collapse difficult to recover from, leaving little economic diversity and a large workforce of unskilled laborers. ${ }^{76}$

\footnotetext{
74 US Census 2000. Demographic Profiles: 100 highest-income places with at least 1,000 households. U.S. Department of Commerce, 1990.

${ }^{75}$ Sam Roberts, "When the City's Bankruptcy Was Just a Few Words Away," The New York Times, December 31, 2006.

${ }^{76}$ Peter Eisinger, "Is Detroit Dead?" Journal of Urban Affairs 36, no. 1 (2014): 1-12.
} 


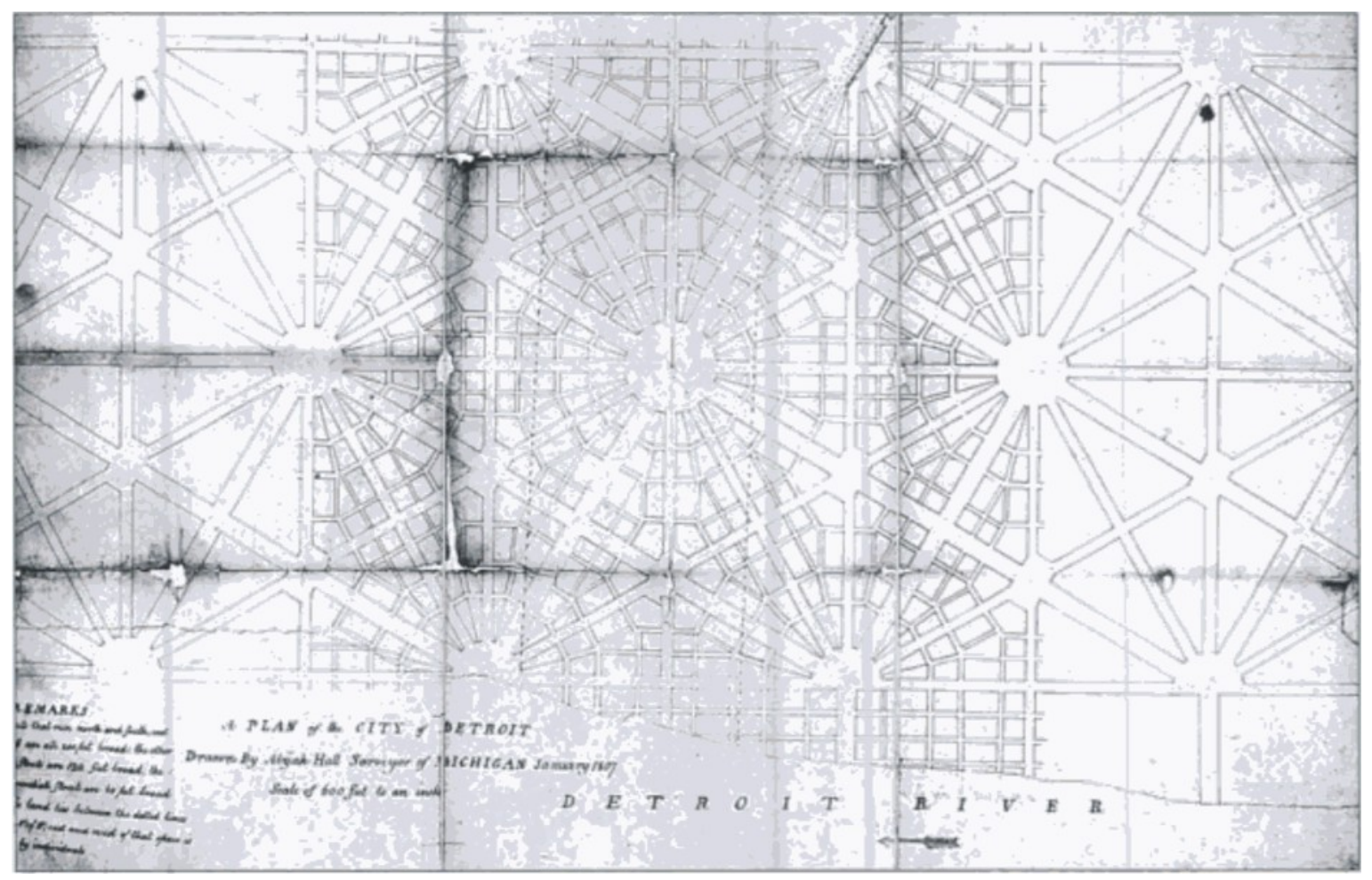

FIG. 20 JUDGE WOODWARD'S PLAN OF THE CITY OF DETROIT: Hull, Abijah. Burton Historical Collection, 1807. 


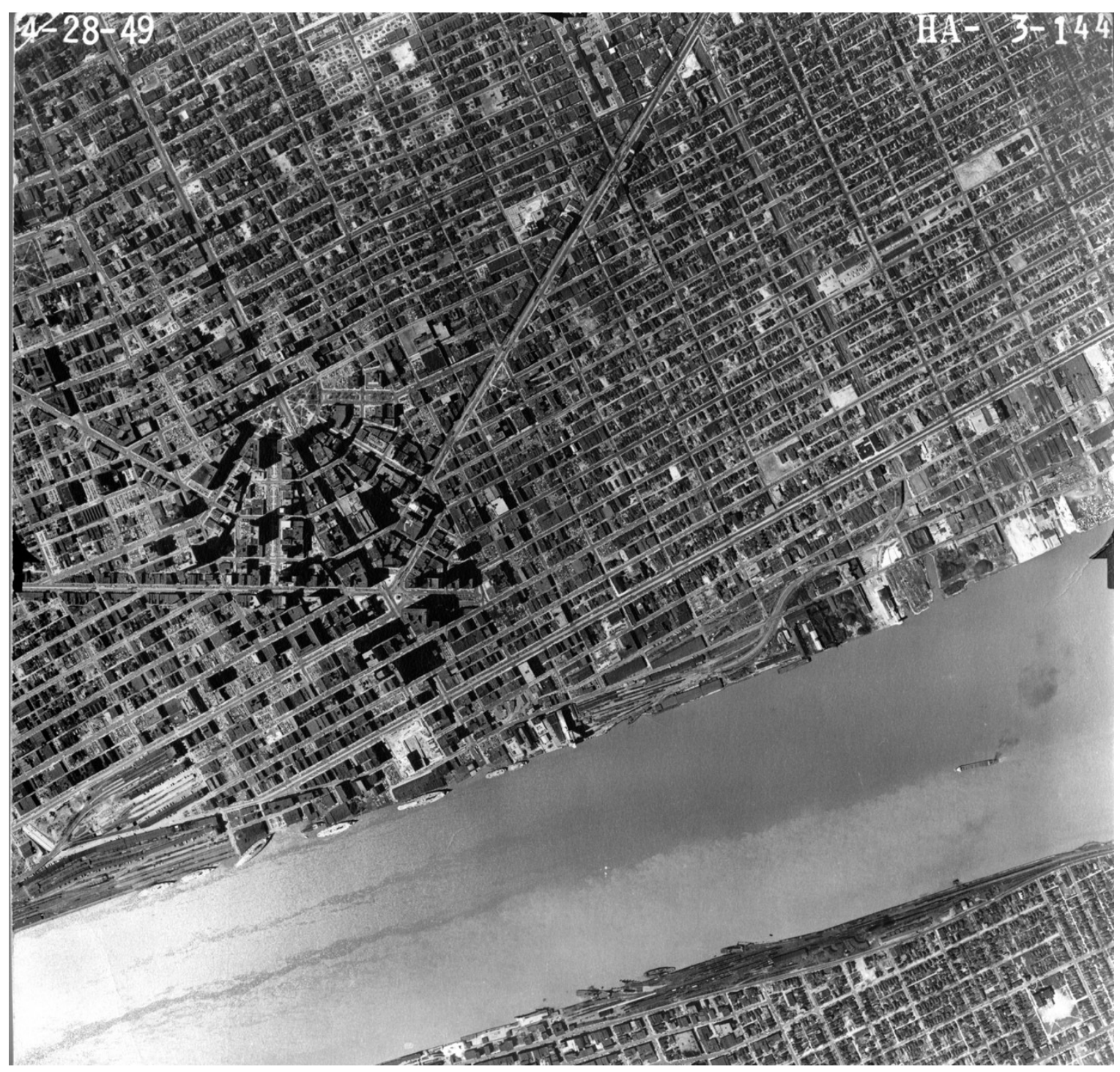

FIG. 21 DETROIT DOWNTOWN AERIAL PHOTOGRAPH 1949: Wayne State University. 


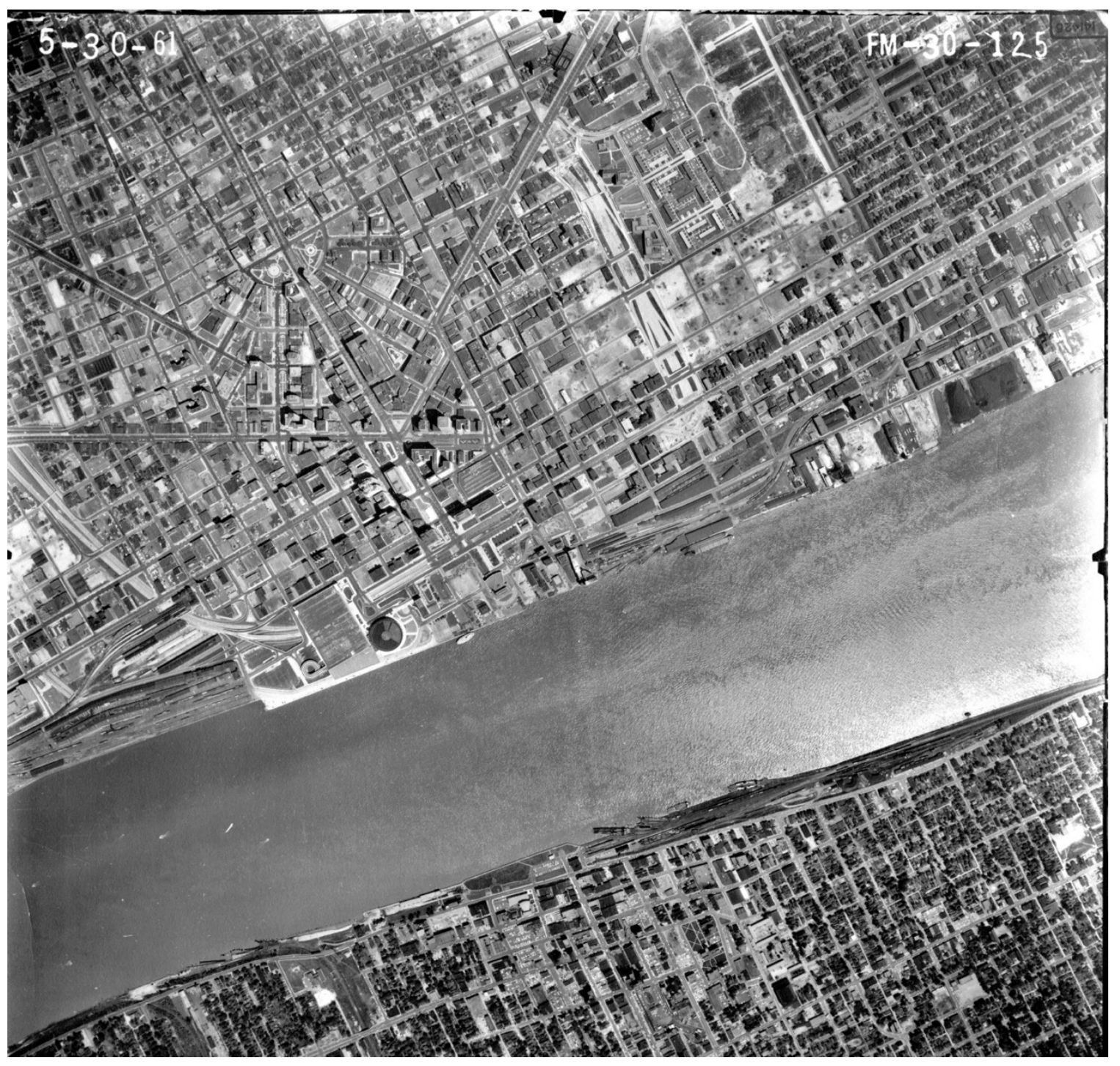

FIG. 22 DETROIT DOWNTOWN AERIAL PHOTOGRAPH 1961 (the first phase of construction of the I-75 freeway and of Lafayette Park, residential development (then known as URMich 1-1, the first urban renewal project in the U.S.) are visible in this aerial): Wayne State University. 
Comparing Detroit to three other major cities

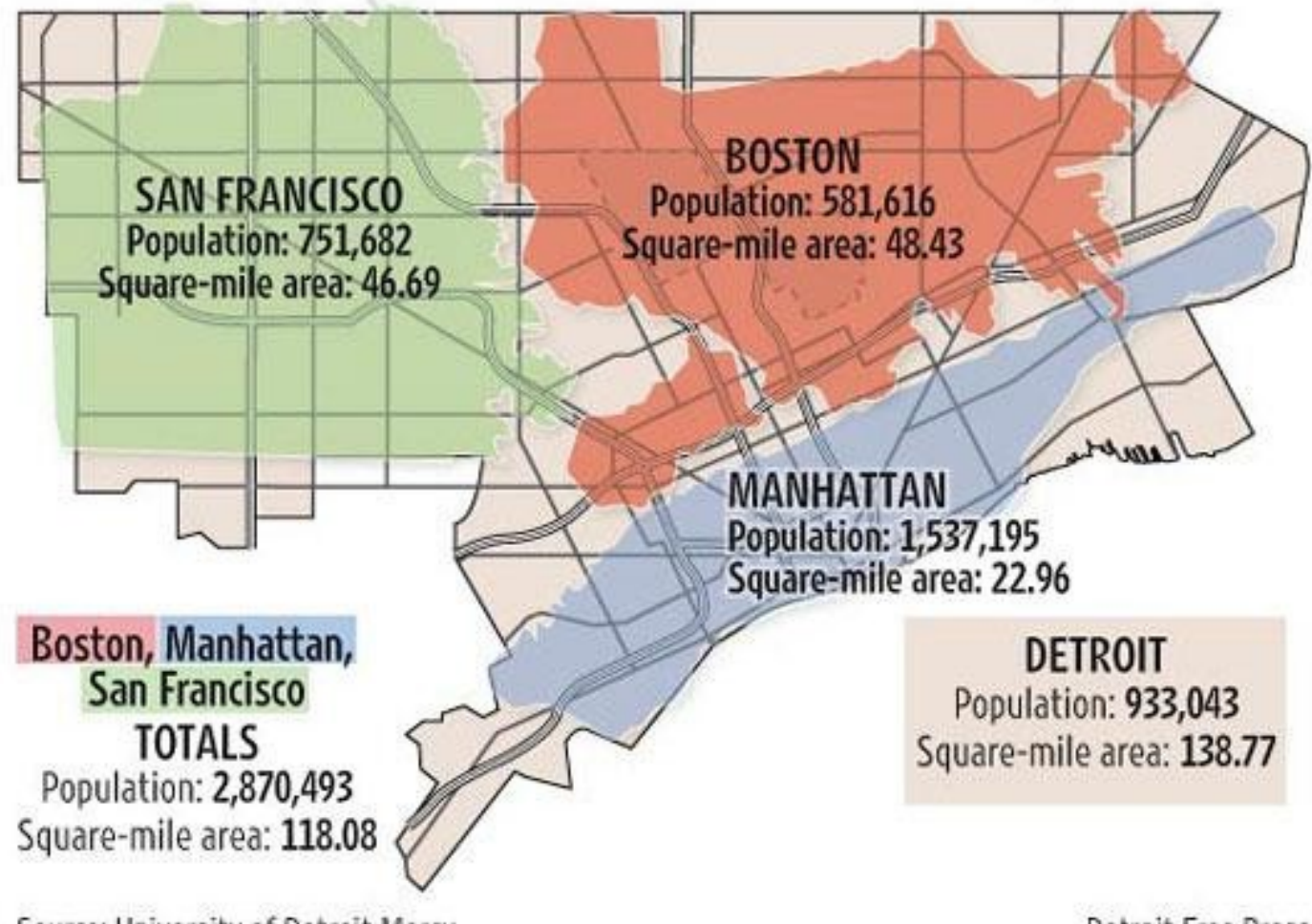

Source: University of Detroit Mercy

Detroit Free Press

FIG. 23 DETROIT CITY SIZE COMPARISON: Pitera, Dan. Cultivating the Shrinking City. King, Jason. March 10th 2010. Accessed February 2014. <http://www.terrafluxus.com/archives/408>. 


\subsubsection{Shrinking City}

Ruin porn, the popular term for the photographic record of Detroit's decline, plays on people's morbid curiosity. Images of Detroit's ruins evoke the powerful force of fate through recognition and identification, as these modern buildings resemble buildings that, in another city, might be active and robust. But while these images suggest a dead city, between 2006 and 2012 Detroit's downtown core has seen $\$ 6$ billion in real estate development, an influx of white-collar employers such as General Motors, Quicken Loans, Blue Cross/Blue Shield, and Compuware, and entertained over 10.5 million tourists. ${ }^{77}$ Despite these advances, however, the population of the downtown core continues to shrink, and the city was forced to file for bankruptcy in July 2013.

In response to its decline, the city has created a long-term plan. In December 2012, after two years of meetings with the community and urban experts, Detroit unveiled its Strategic Framework Plan entitled 'Detroit Future City.' The conventional urban strategy for dealing with decline is to build new developments and hope that population growth will follow. The Detroit Future City plans, however, acknowledge that the population will not rebound and instead adopts strategies to concentrate the current population in the core and to efficiently manage very large green spaces occupied by very low populations within the city boundaries.

Filing for bankruptcy has left the city in a state of uncertainty, with city assets such as its fine art collection and Belle Island at risk of being sold off. The city appears to be in dire straits. Growth has conventionally been understood as an

${ }^{77}$ Eisinger, "Is Detroit Dead?" 
absolute necessity in a capitalist economy, so a city accepting decline is unfamiliar territory, but decline is part of a natural growth cycle, a transition period and a reality that all cities have to face periodically. The fundamental characteristic of a sustainable system is a cyclical progression, so it stands to reason that a linear progression is a system bound for inevitable collapse. The barrier to achieving a healthy system of growth and decline is within the minds of the people who perceive decline as a fatal condition. Instead, decline should be seen as an opportunity to restructure the outmoded fabric and innovate new solutions. Ruins are rife with possibility, but when photographed with heavy contrasts, faded colours and dramatic lighting the artists are leading an interpretation of demise. By reversing preconceptions, the city can take advantage of transformative energies and relish its period of unmaking. As the world begins to reach its population capacity, other cities could look to Detroit as an innovator in envisioning a stabilized economy with a declining or stagnant population. As Aristotle once said, "A great city should not be confounded with a populous city."78

\footnotetext{
78 Tanvi Manheshwari, "Redefining Shrinking Cities," (2013): n. pag. The Urban Fringe. Web. 26 Mar. 2014. Accessed March 9, 2014, http://ced.berkeley.edu/bpj/2013/12/redefining-shrinking-cities/
} 


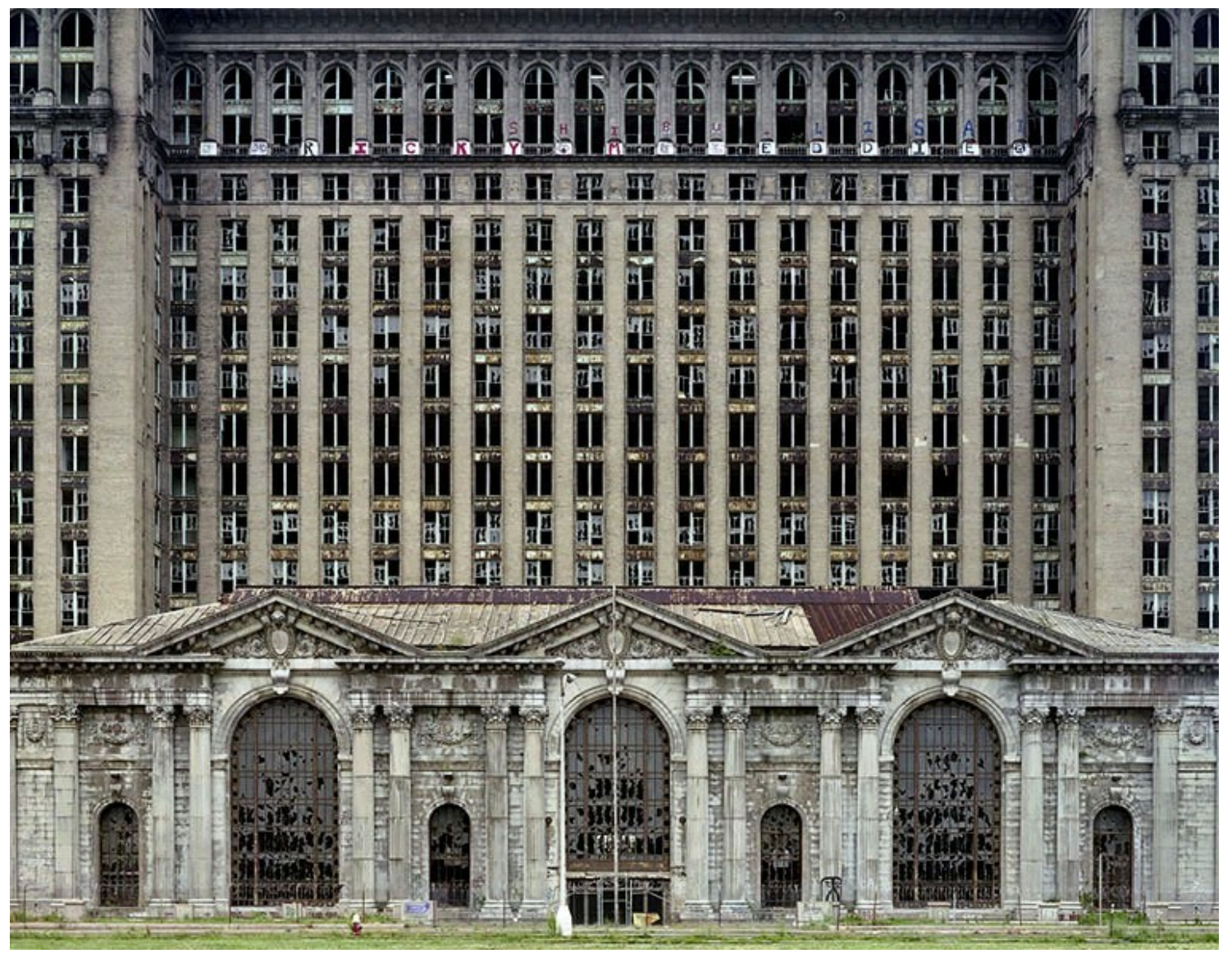

FIG. 24 MICHIGAN CENTRAL STATION: Marchand, Yves. Meffre, Romain. Polidori, Robert. Sugrue,Thomas J. The Ruins of Detroit. Göttingen: Steidl, 2010. Cover. 


\section{Conclusions of Part One}

By adhering to the cyclical progression of construction, deconstruction, and reconstruction, architectural design could create a sustainable system of material reuse that would be beneficial to the earth's ecology, the end user and the urban environment. The scenario that needs to be active in order to enable this system is twofold; the transience of physical buildings needs to be recognized as an architectural ideal and a market for architectural salvage needs to be established to convert the material back into production. The architect initiates the process of design for disassembly, establishing intent to deconstruct and the salvage yard completes the process by accepting the materials. Under these circumstances the profession of the wrecker evolves from generating wreckage to creating artifacts through the unmaking of architecture. 


\section{Part Two}

\section{Chapter One: Site Study}

\section{"Architecture is now little more than a thermal barrier-against cold in the north, against the heat in the south-its mirror-glass facades a perverse premonition of future non-existence" -Rem Koolhaas, 1991}

The site chosen for this project sits along the Detroit waterfront, just east of the Central Business District. Since the city is working towards shrinking its core, a site adjacent to the city's downtown is a sensible area for new development. The site is a block bounded by Franklin, Riopelle, Rivard, and Atwater Streets. This block was selected for the considerable assets surrounding it, its historical foundations and the potential for a variety of appropriate programs.

\subsubsection{Site Context}

Context studies completed at a medium scale of a one-kilometer radius around the chosen block guide the future design and better acclimate it within the current urban framework. The figure-ground study (FIG. 25) communicates the typical building footprints in the area and their relationship with the urban fabric. For instance, west of the site is Detroit's central business district, so the buildings have large footprints that fill the majority of a small block within a compact and congested grid. North of the site, however, is the residential community known as Lafayette Park, where the block is very large and open, allowing for plenty of park space, while the building footprints are long and skinny and arranged in small 
clusters. The waterfront area surrounding the site is an intermediate between those two conditions: the grid is looser than downtown but the footprints are much larger than in the residential area. The waterfront has a number of voids, leaving plenty of opportunity for new projects.

The study of Detroit bus routes (FIG. 26) shows that they converge around the downtown core, designed to support white-collar commuters. A major bus route linking to the core passes only two blocks north of the site. This vein travels east to west, along Jefferson, uniting the waterfront. The site is also in walking distance from a major bus hub to the west of the block, in front of the Renaissance Center.

The land use study (FIG. 27) presents the model functions of each neighbourhood. The open park space bordering the river is a means to separate the mixed-use spaces from the natural ecosystem of the river and its banks. The busy roadway of Jefferson Avenue encourages commercial growth and creates a buffer zone for the residential area of Lafayette Park behind it. The downtown core is almost entirely devoted to commercial uses, while institutional programs are dispersed throughout the area. 


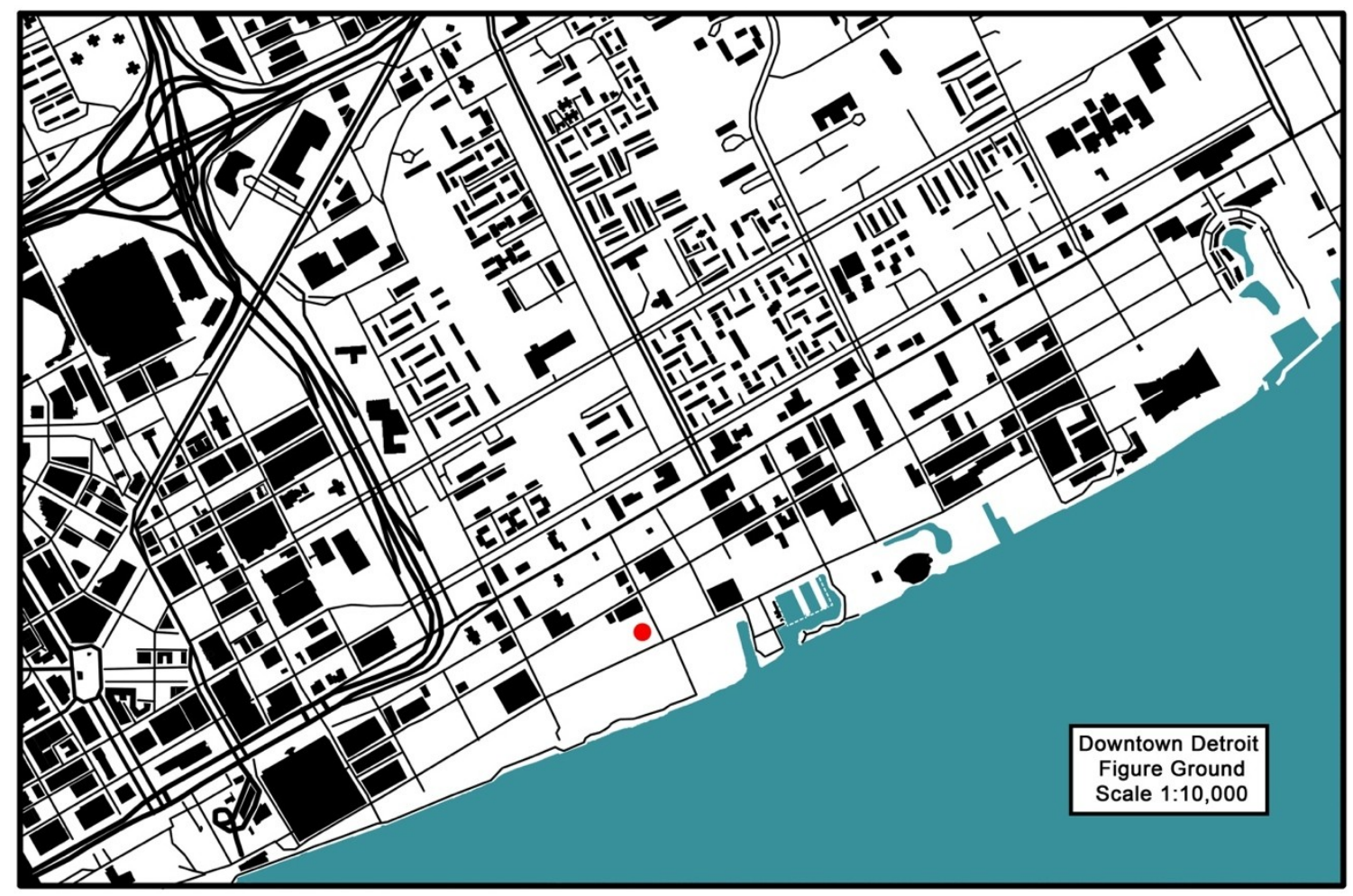

FIG. 25 DETROIT FIGURE GROUND: McKeracher, Colleen. 2013.

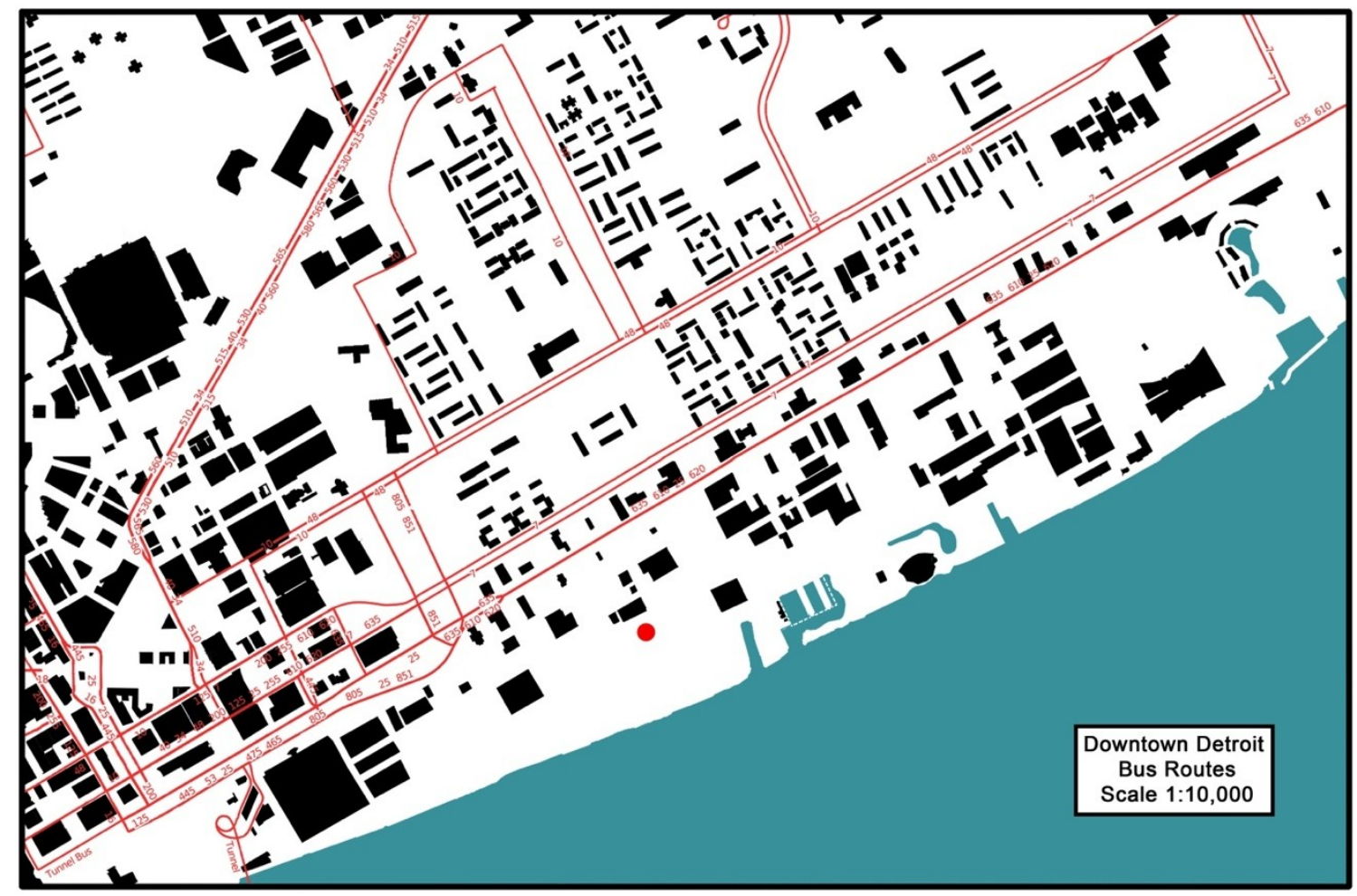

FIG. 26 DETROIT BUS ROUTES: McKeracher, Colleen. 2013. 


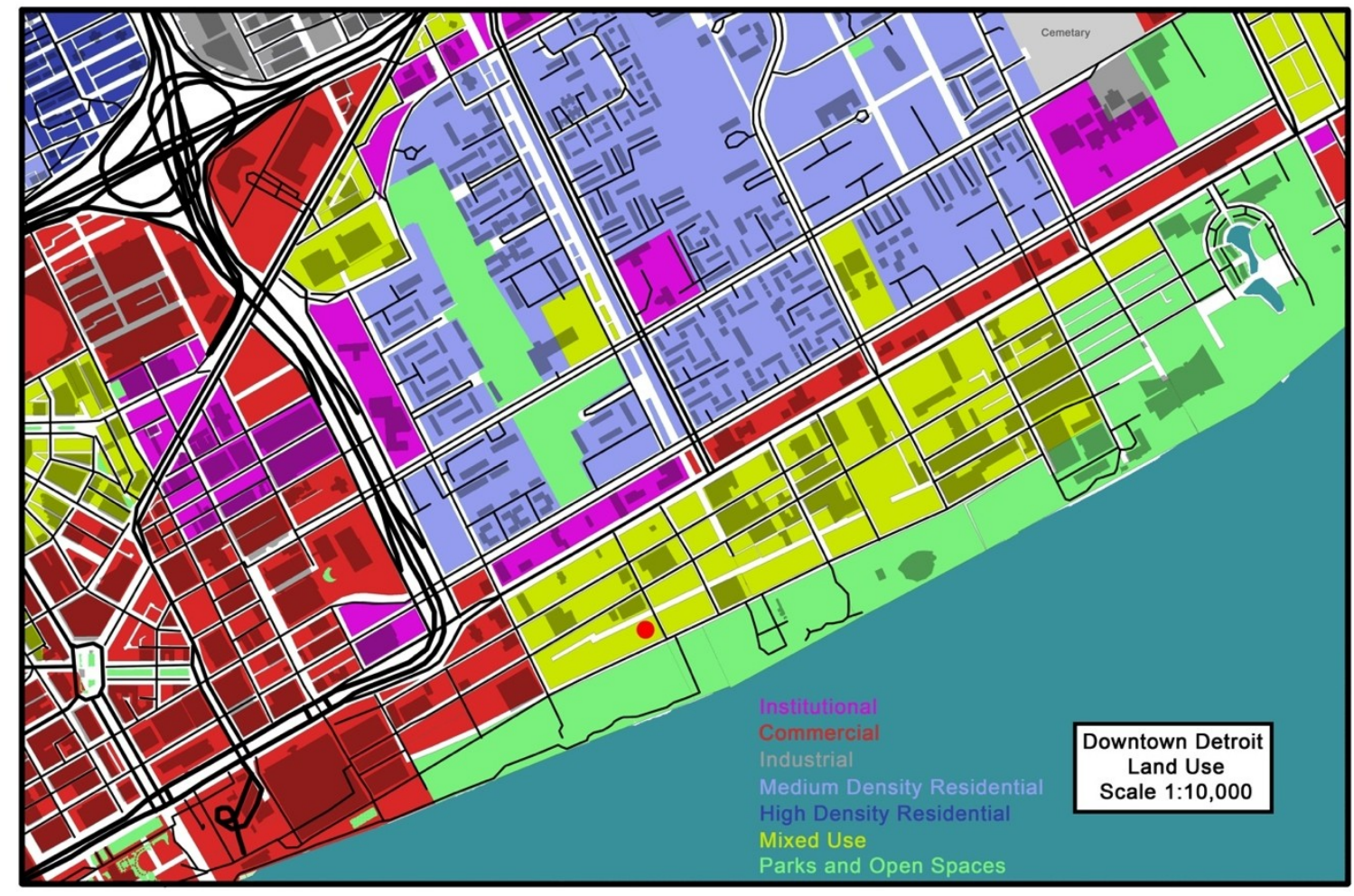

FIG. 27 DETROIT LAND USE: McKeracher, Colleen. 2013.

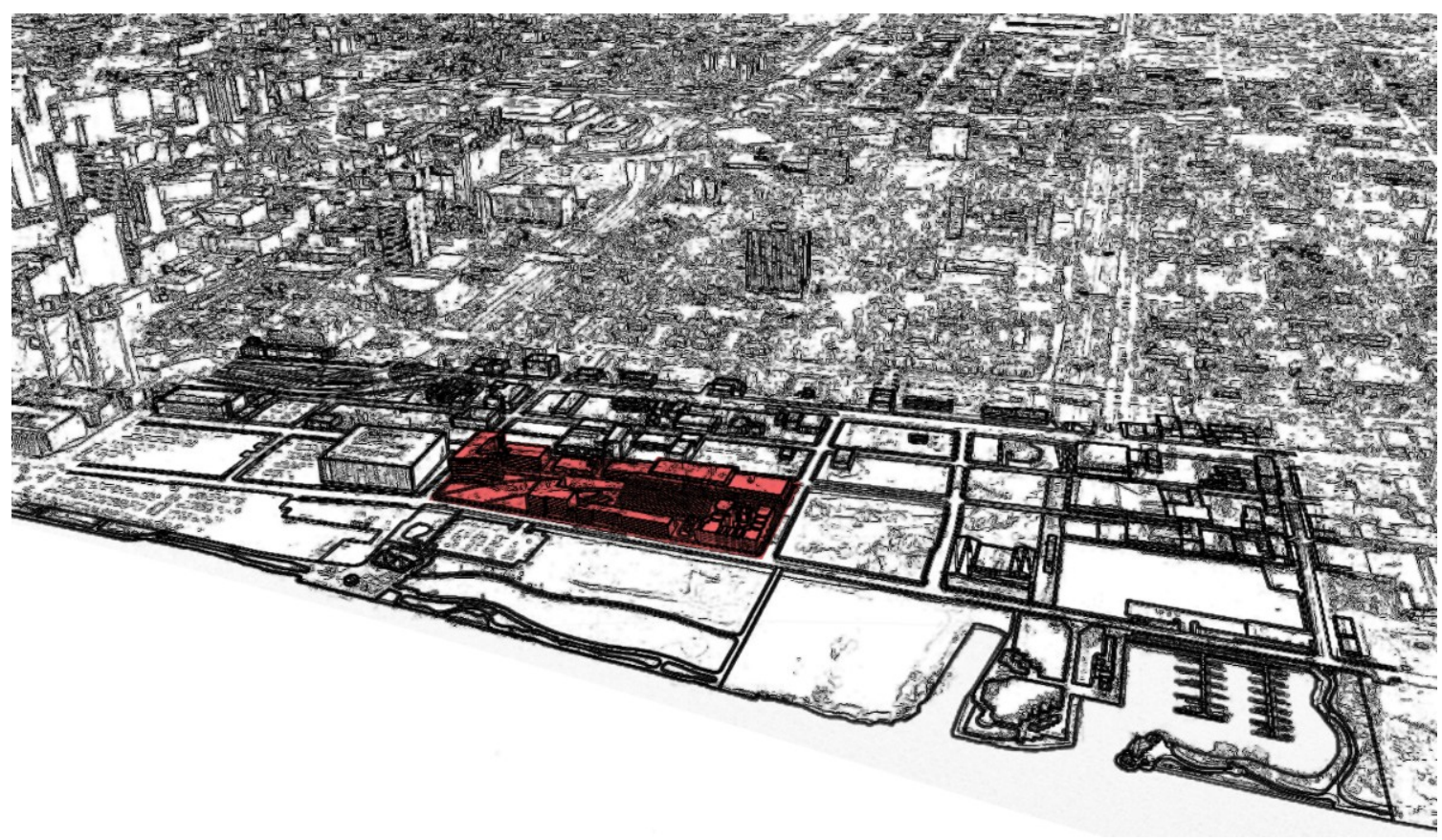

FIG. 28 CONTEXT OF THE SITE: McKeracher, Colleen, 2014. 


\subsubsection{Site Assets and Anticipated Developments by the City of Detroit}

The riverfront has already experienced considerable rejuvenation through a project known as the RiverWalk. The RiverWalk currently occupies 3.5 miles along the Detroit River, with green spaces, fountains, a rest stop with bike rentals, washrooms, and a café, and even more plans for expansion. ${ }^{79}$ Amenities like a carousel, beach volleyball court, and playground make the RiverWalk a destination for families and tourists. This rejuvenation has also resulted in city upgrades to the surrounding roadways, including new pavement, sidewalks, and street furniture. The non-profit organization responsible for the RiverWalk is known as the Detroit Riverfront Conservancy, whose mission is to create an "exciting, safe, accessible, world-class gathering place for all."80

The Detroit Riverfront Conservancy is also responsible for the Dequindre Cut, a pedestrian trail that connects the famous Detroit Eastern Market to the RiverWalk. Opened in May 2009, the 1.5-mile path is mostly below grade, allowing bicyclists and pedestrians to enjoy an outdoor green space uninterrupted by city traffic. The cut surfaces just south of East Jefferson Avenue and continues on grade to meet up with the RiverWalk. This space has been reclaimed from its inoperative existence as the defunct Grand Trunk Western rail line, which had become a haven for vagrants and graffiti artists. Originally the rail line cut west after crossing south of Franklin Street onto a street known as Guoin. The city still recognizes Guoin on their zoning map, (FIG. 29) and have even lowered the sidewalk for vehicles to enter even through

\footnotetext{
79 "East Riverfront," Detroit Riverfront Conservancy, accessed March 26, 2014, http://detroitriverfront.org/riverfront.

80 "Vision \& Mission," Detroit Riverfront Conservancy, accessed March 26, 2014, http://detroitriverfront.org/our-story/vision-mission.
} 
the street remains unpaved and has no signage to identify it (FIG. 30). Although the actual tracks were removed long ago, the traces of their existence are still visible from satellite imagery.

At the South end of the Dequindre Cut, at the corner of Atwater and Orleans Street, the Globe Trading Building, which originally operated as a dry dock for ships, is a ruin currently in reconstruction. This hundred-year-old structure is being transformed into a recreation center designed to appeal to families and young adults. Much of the original structure has been demolished due to its age and years of neglect, but some of the structural, foundation, and exterior walls have been restored. The new sections of the building will echo the original peaked roof forms and preserve some likeness to the brick facades of the traditional industrial architecture. This new project, known as the Outdoor Adventure and Discovery Center, has been a catalyst for new development as a new residential community is currently being considered that would surround the new center and the Dequindre Cut. The development would consist of five blocks of mixed, low-rise townhouses and apartments with ground level small-scale retail (FIG. 31 and FIG. 32). ${ }^{81}$ Wayne County has offered political and financial support for this endeavor, ${ }^{82}$ and so construction is a real possibility, not just speculation. The developer, McCormack Baron Salazar, predicts demand for downtown housing and is targeting the young professional and empty nester demographics, anticipating rents between $\$ 850$ and

${ }^{81}$ J.C. Reindl, "\$60M East Riverfront Development in Detroit to Bring Housing, Streetscape," Detroit Free Press, July 23, 2013, http://www.freep.com.

82 Ibid. 
$\$ 1700.83$ Two to three story buildings would line the street edge, with interior space for on-grade parking. ${ }^{84}$ In the current design, Guoin Street is resurrected as Guoin Mews. The success of the project could result in a second phase that would expand into this thesis's site block. ${ }^{85}$

The site's zoning designation is SD4, denoting a special development district known as Riverfront Mixed Use, which encourages "high intensity residential and commercial mixed use developments." ${ }^{86}$ Detroit needs to foster the unique amenities within this area, in order to avoid an overcrowded population, street congestion, or hazards to life and property.

${ }^{83} \mathrm{Ibid}$

84 Ibid.

85 Ibid.

${ }^{86}$ Detroit Zoning Ordinance: Chapter 61 of the 1984 Detroit City Code, as Amended. Detroit, MI: City Planning Commission, April 16, 2013. 


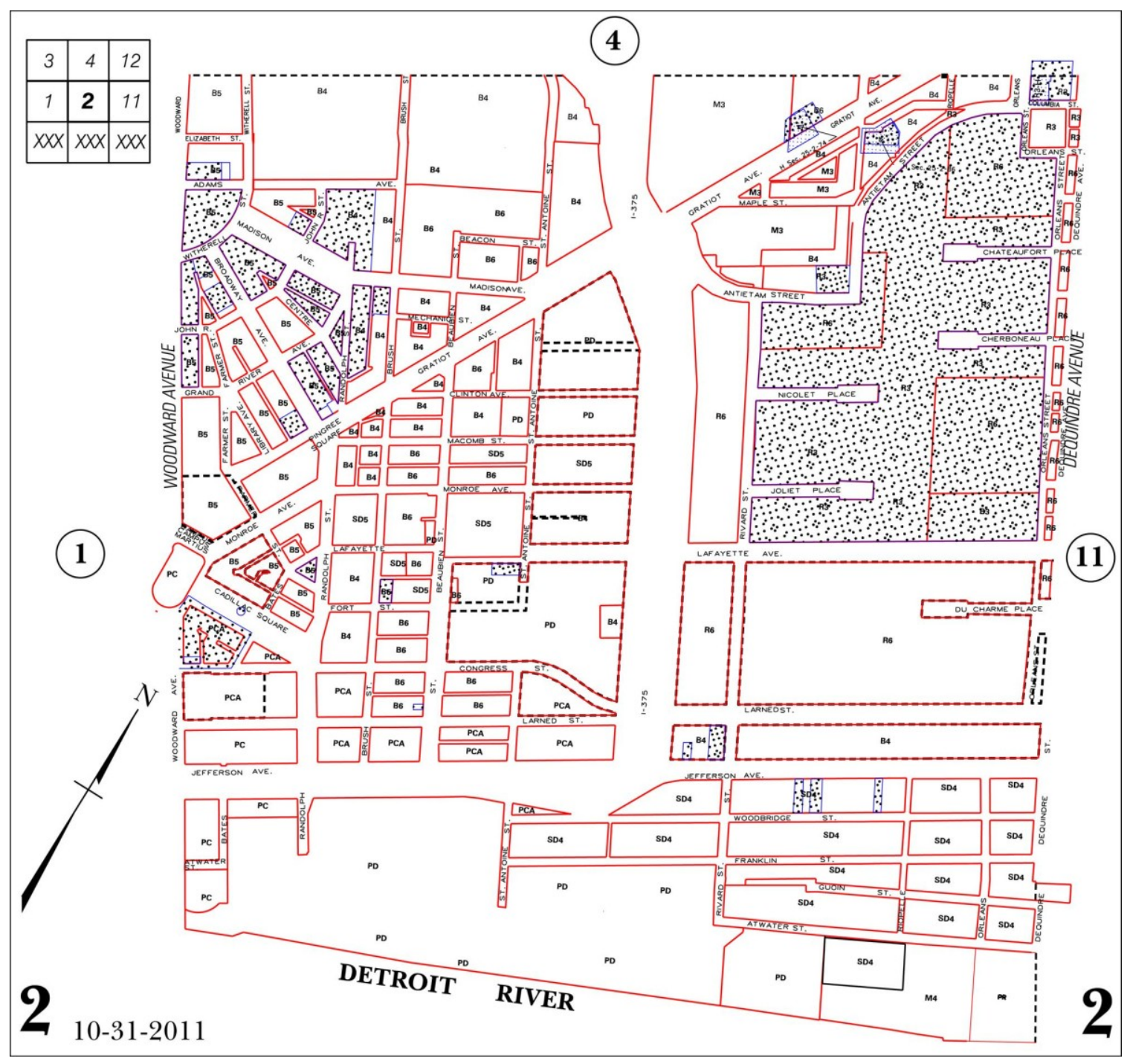

FIG. 29 DETROIT ZONE 2 MAP: Detroit Zoning Ordinance: Chapter 61 of the 1984 Detroit City Code, as Amended. Detroit, MI: City Planning Commission, 16 April 2013. 


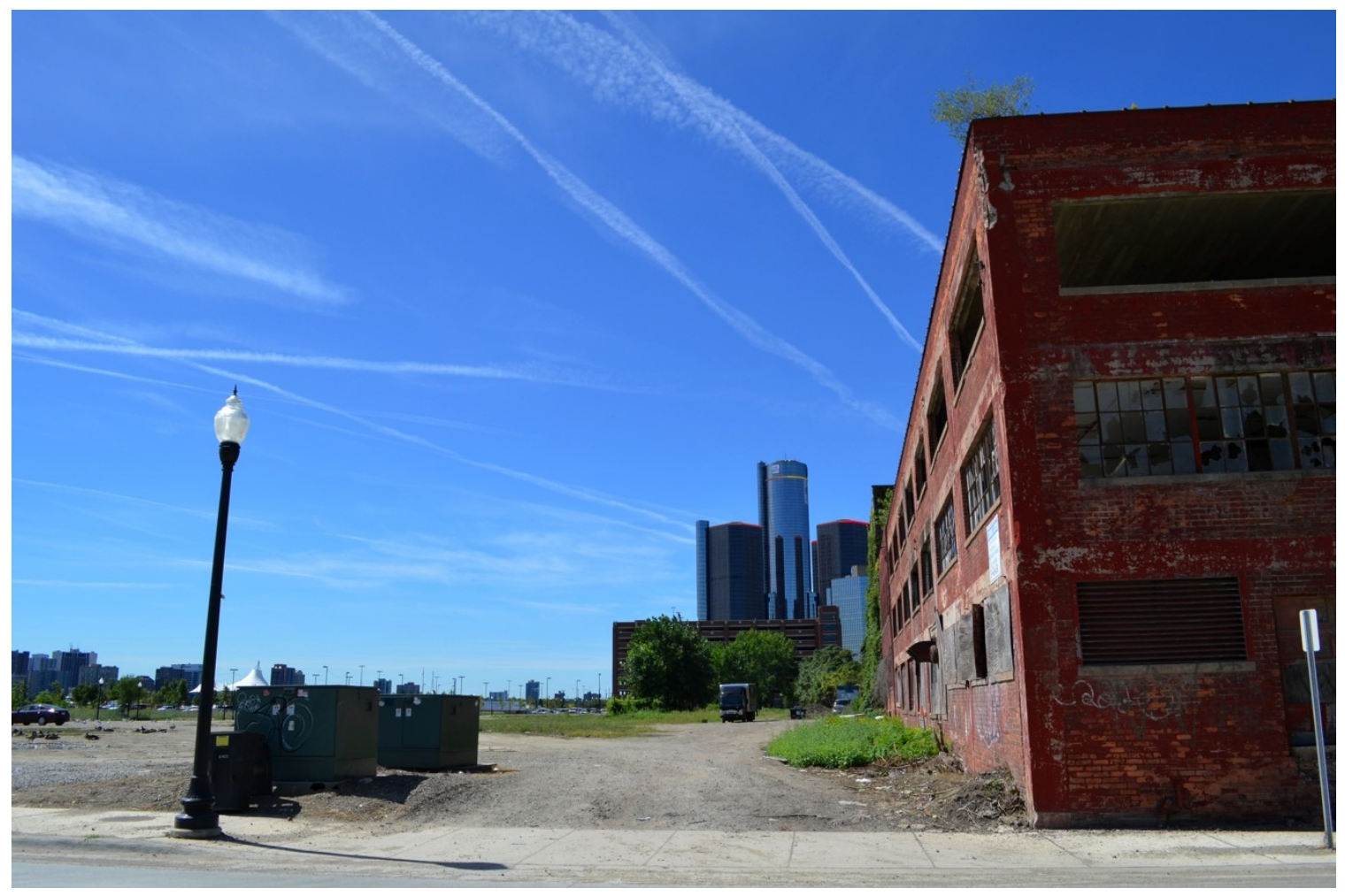

FIG. 30 DETROIT LOOKING DOWN GUOIN STREET FROM RIOPELLE STREET: Mckeracher, Colleen. 2013.

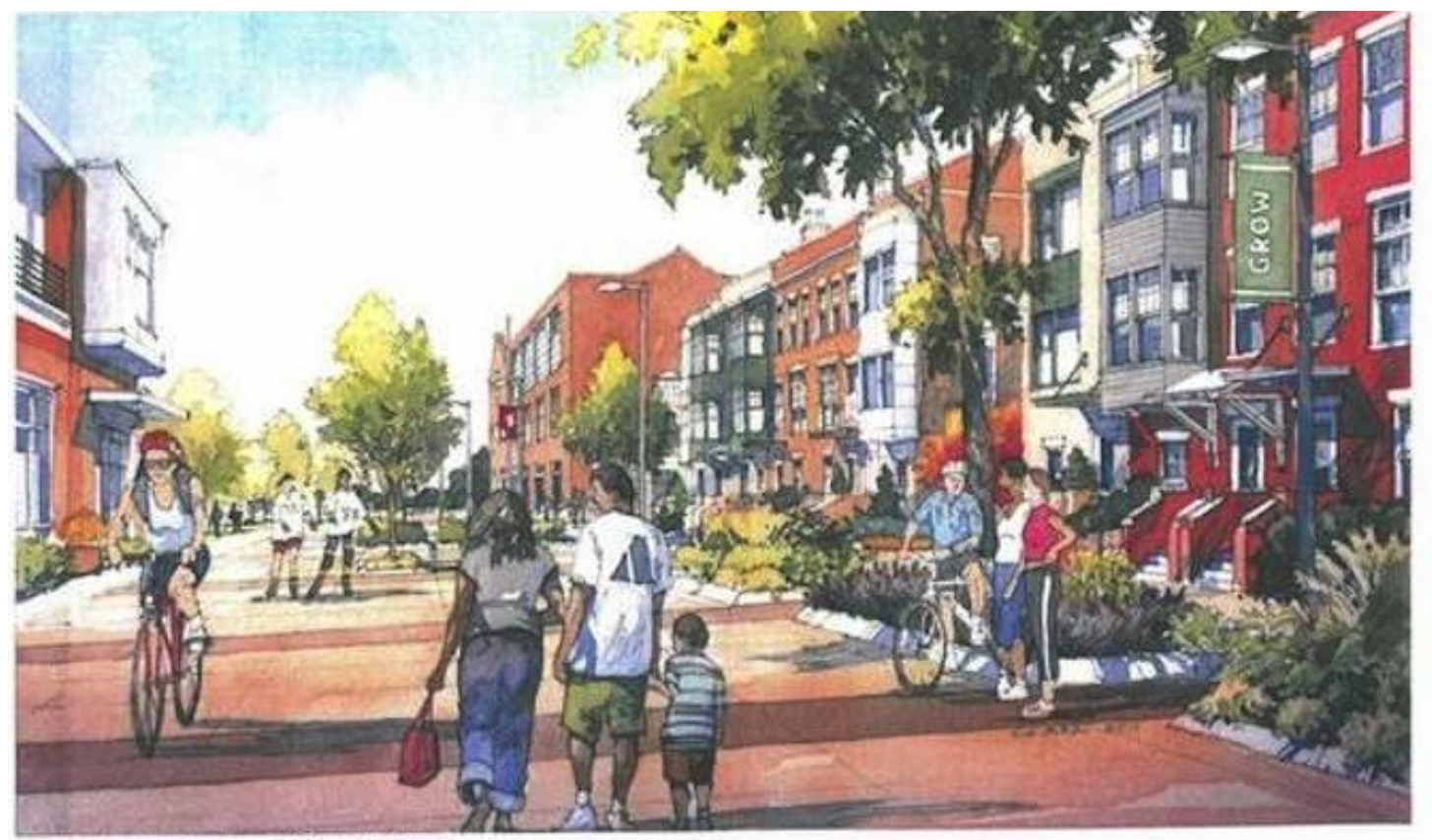

FIG. 31 DETROIT GREENWAY TRAIL VIEW (LOOKING SOUTH): East Riverfront Revitalization Implementation Plan, McCormack Baron Salazar, 2012. 


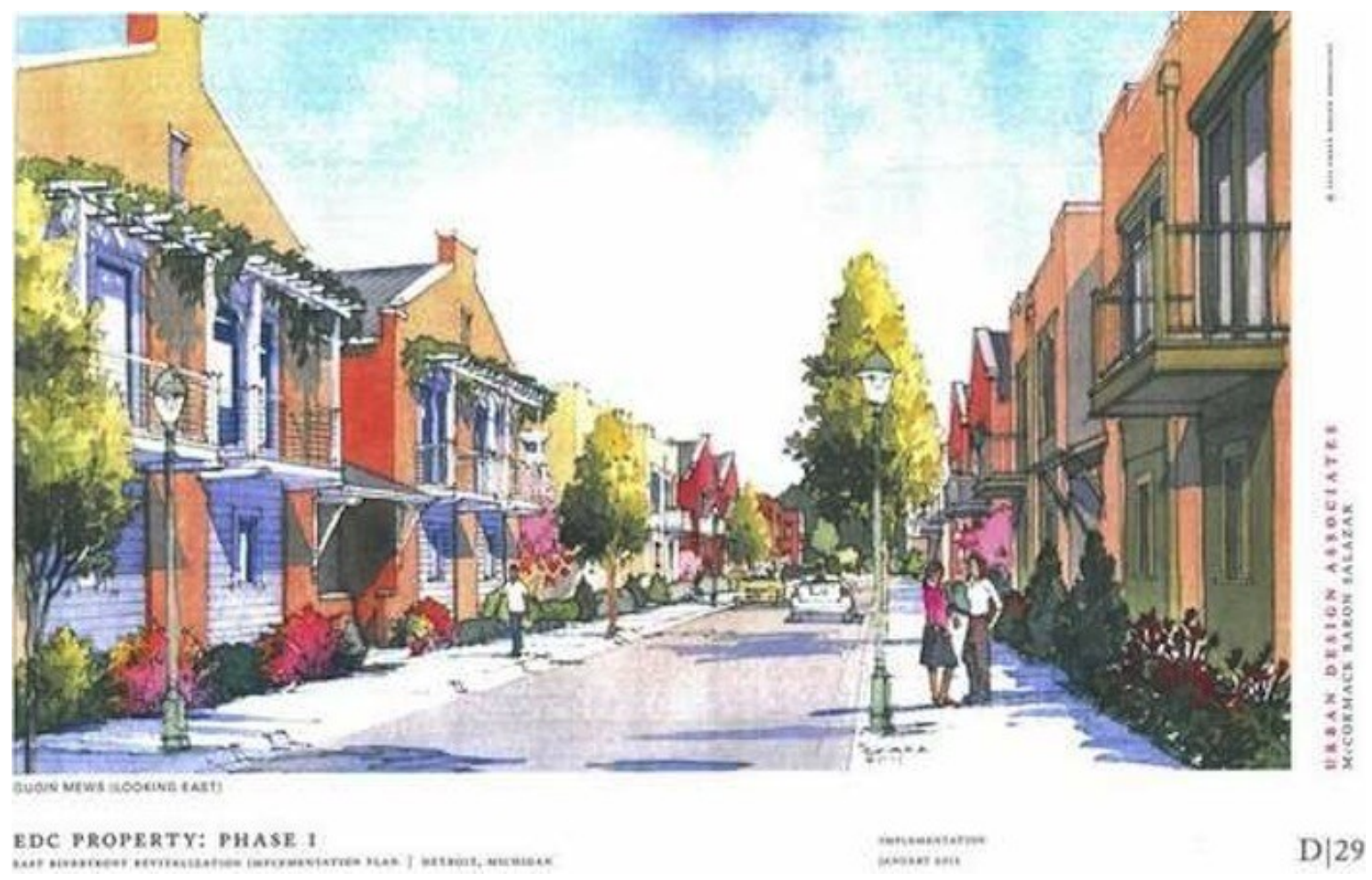

FIG. 32 GUOIN MEWS (LOOKING EAST): East Riverfront Revitalization Implementation Plan, McCormack Baron Salazar, 2012.

\subsubsection{Site History: The Detroit Screw Works and Other Notable Past Structures}

When the earliest Sanborn Insurance drawings for this area were created in 1884, a conglomeration of small buildings and material yards occupied the site surrounding the Grand Trunk Railway System. The rail line entered the site along Guoin Street from the east as three tracks, and began to diverge into a multitude of tracks as it moved towards the Southwest corner into the neighbouring rail yards. The subsequent Sanborn Insurance maps of 1897 show an industrial expansion with the introduction of two large factories occupying the area south of the rail lines. The Detroit Screw Works was a three-story factory situated within a production core served by the trains and ships, evident on a lithograph created of the building featuring numerous smoke stacks and an active roadway (FIG. 34). This is indicative 
of the burgeoning large industrial businesses that were displacing the previous forms of tight live/work residential houses. The Detroit Screw Works was awarded permission by the city to extend a track from the Guoin line into their yard on May $16^{\text {th }}, 1892,{ }^{87}$ so we can infer that it was around this time that the factory was constructed. The other major addition to the 1897 Sanborn maps was the Citizens Street Railway Power House, which served Detroit's growing streetcar industry. 88 The following Sanborn drawing of 1922 establishes that that Power House had transferred ownership to the Detroit United Railway. In FIG. 33, a photograph from 1910 showing the intersection of Franklin and Riopelle, facing east of the site, portrays the houses that were characteristic of the area and period, a mixture of two story wood and brick construction that accommodated both residential uses and small scale retail stores.

The 1922 Sanborn drawings have very little in common with the site from 40 years earlier; all the small buildings had now been replaced with large factories and industrial storage. On the Northeast corner of the site the Eaton-Clark Chemical and Dyestuff Company had built a large storage facility. When Eaton-Clark's original factory on Woodward and Atwater became inadequate in 1927, the company was forced to rebuild on their industrial storage site on the corner of Riopelle and Franklin. ${ }^{89}$ The new concrete structure buttressed two older wooden structures, also owned and operated by the Eaton-Clark Company as warehouses. These

\footnotetext{
${ }^{87}$ Fred R. Schmalzreidt, Compiled Ordinances of Detroit of 1912 (Detroit.: Houghton-Jacobson, 1912), 799.

${ }^{88}$ Kenneth Schramm, Detroit's Street Railways (Charleston, SC: Arcadia, 2006).

89 "Michigan's Oldest Industrial Firm," Detroit Trust Company Quarterly (Summer-Autumn, 1946): 5, $6,8$.
} 
structures remain standing today, although they show decades worth of abandonment and neglect. The firm of Louis Kamper, a famous Detroit architect, marked a lithograph of these buildings (FIG. 35), suggesting Kamper had a personal role in the design of the newest Eaton-Clark building. Louis Kamper was responsible for numerous downtown skyscrapers, completing the notable Book Tower just one year before the Eaton-Clark building was built. Kamper completed over a hundred industrial and residential buildings over his career and although this building was not one of his more noteworthy works, his significance to Detroit architecture elevates this building's importance..$^{90}$

Another structure of note on the 1922 map is a new Detroit Screw Works, built along the west side of the former building, which subsequently became a cotton warehouse. The new Screw Works has an unusual 'I' shaped foundation and persisted on the site until its demolition in $2005,{ }^{91}$ although photographic evidence suggests it was abandoned well before 1980 (FIG. 37). A construction date has not been discovered, although an online blog, detroitfunk.com, suggests the factory was built in $1912 .{ }^{92}$ This corresponds to the time period between the Sanborn maps, although the blog provides no evidence to support the claim. This area was hit hard by the early 1980s recession in America, much like the rest of Detroit, and industry never return to the area, leaving many factories and warehouses abandoned.

\footnotetext{
90 Lucas C. McGrail, "Louis Kamper," Historic Detroit, accessed January 9, 2014, http://www.historicdetroit.org/architect/louis-kamper.

${ }^{91}$ A. Dubs, "The Detroit Screw Works," Faded Detroit, April 25, 2005, http://fadeddetroit.blogspot.ca/2005/04/detroit-screw-works.html.

92 "Detroit Screw Works," dETROITfUNK, March 29, 2003, http://detroitfunk.com/?p=4036.
} 


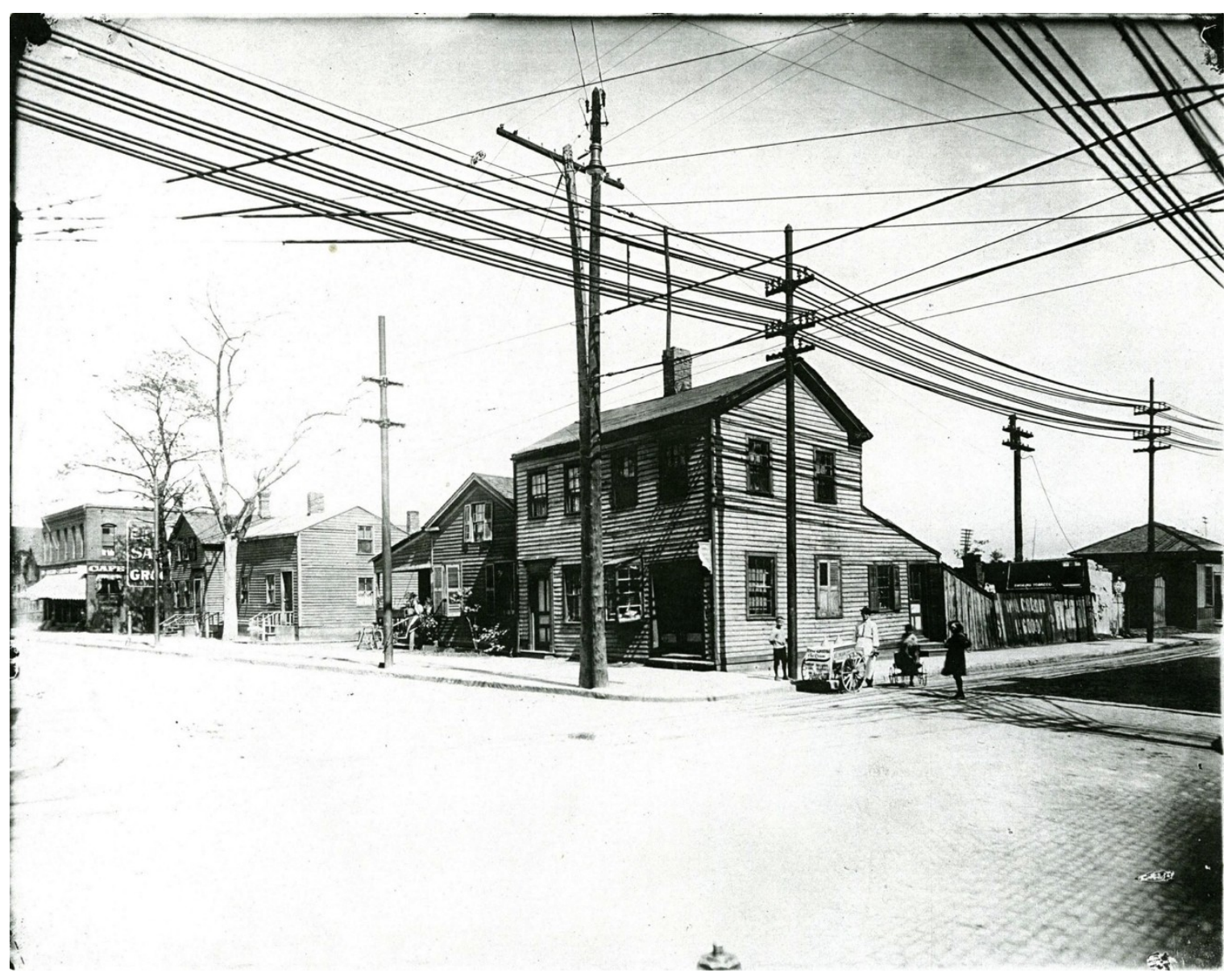

FIG. 33 INTERSECTION OF FRANKLIN AND RIOPELLE: Burton Historical Collection, 1910.

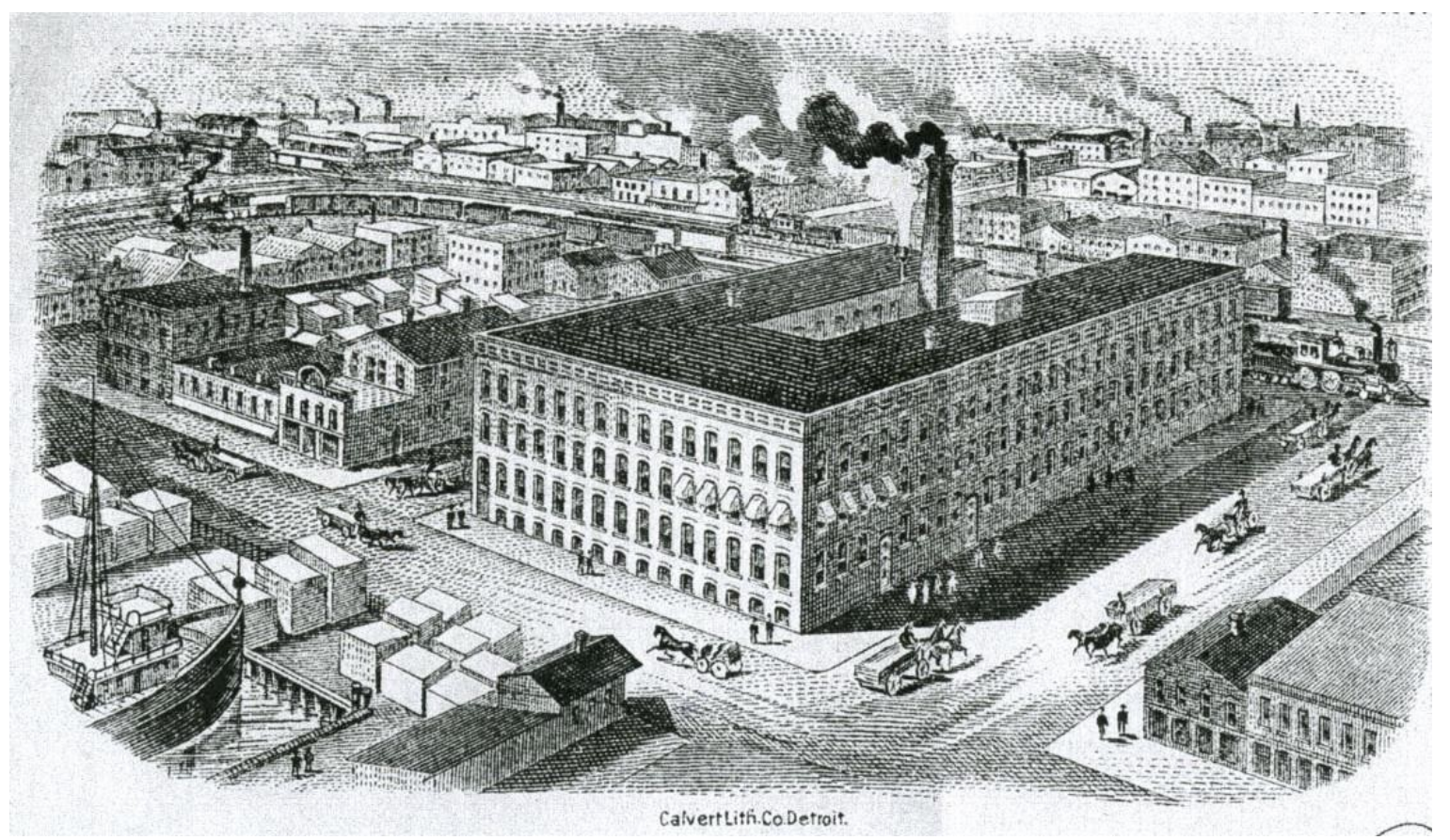

FIG. 34 DETROIT SCREW WORKS LITHOGRAPH: Burton Historical Collection. 


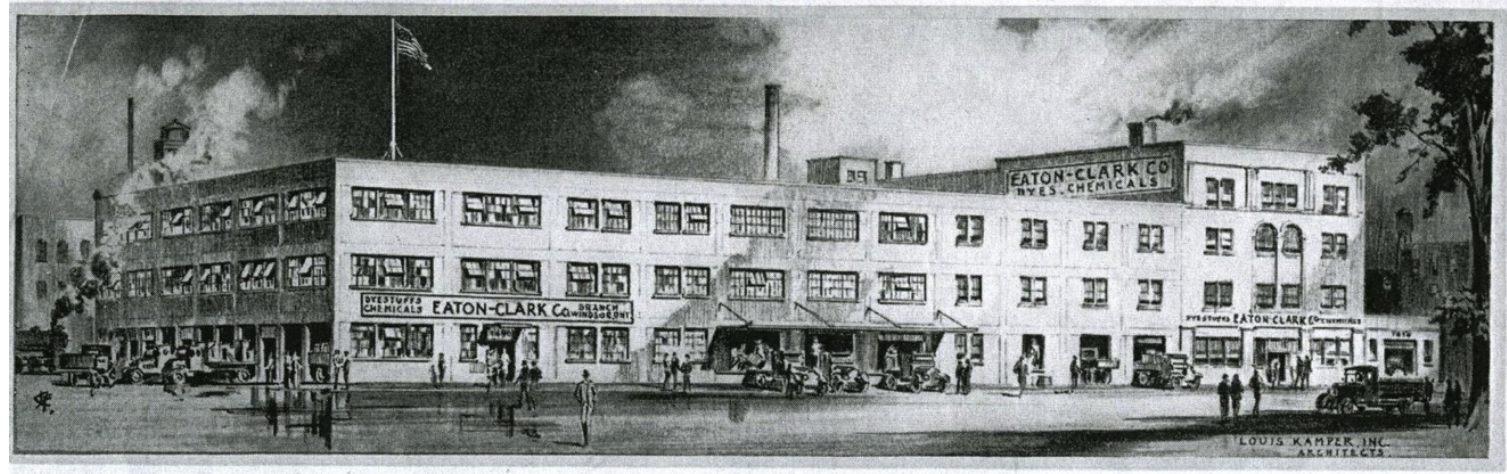

FIG. 35 EATON-CLARK CHEMICAL AND DYES LITHOGRAPH: Burton Historical Collection.

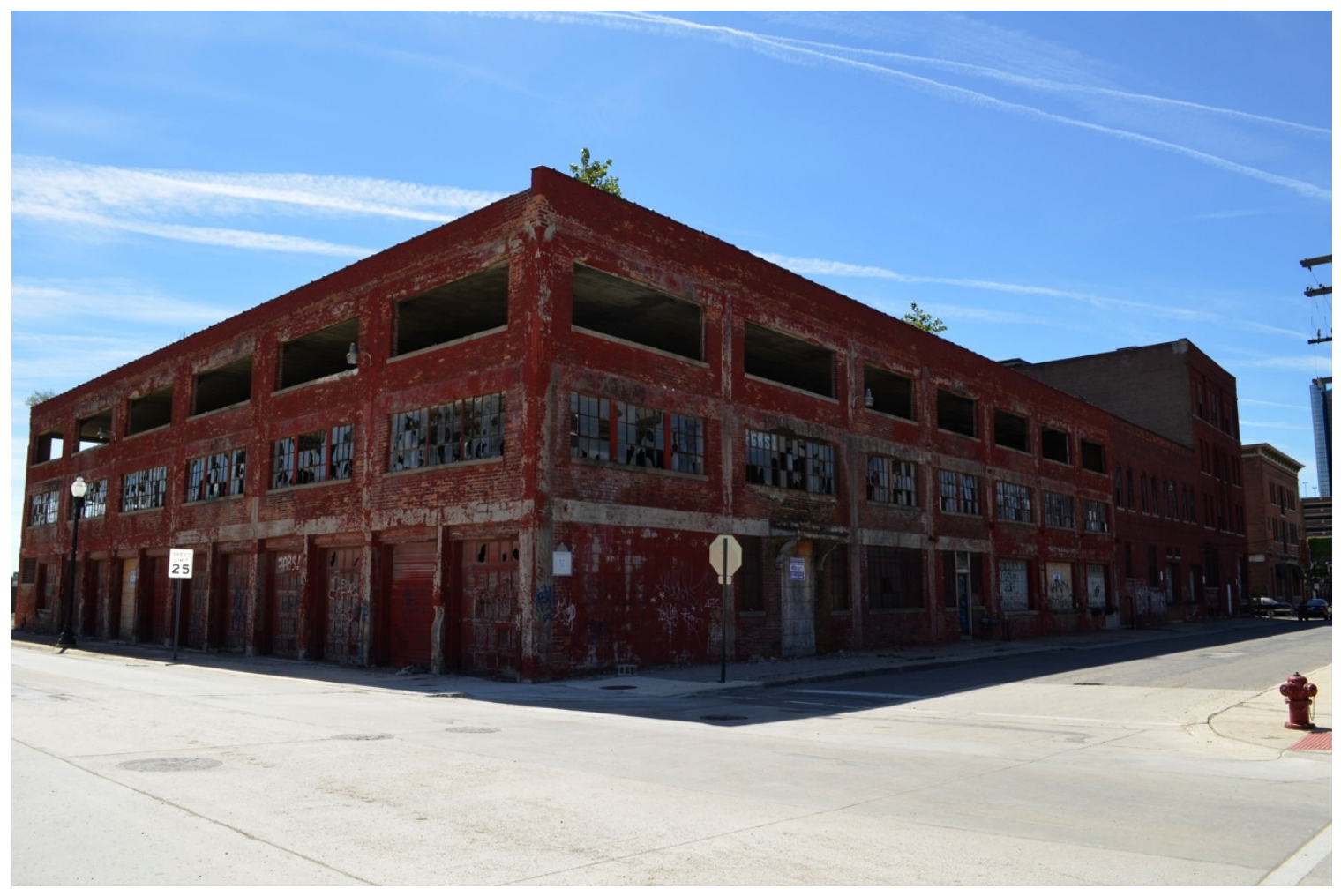

FIG. 36 EATON-CLARK CHEMICAL AND DYES PHOTOGRAPH: McKeracher, Colleen. 2013. 


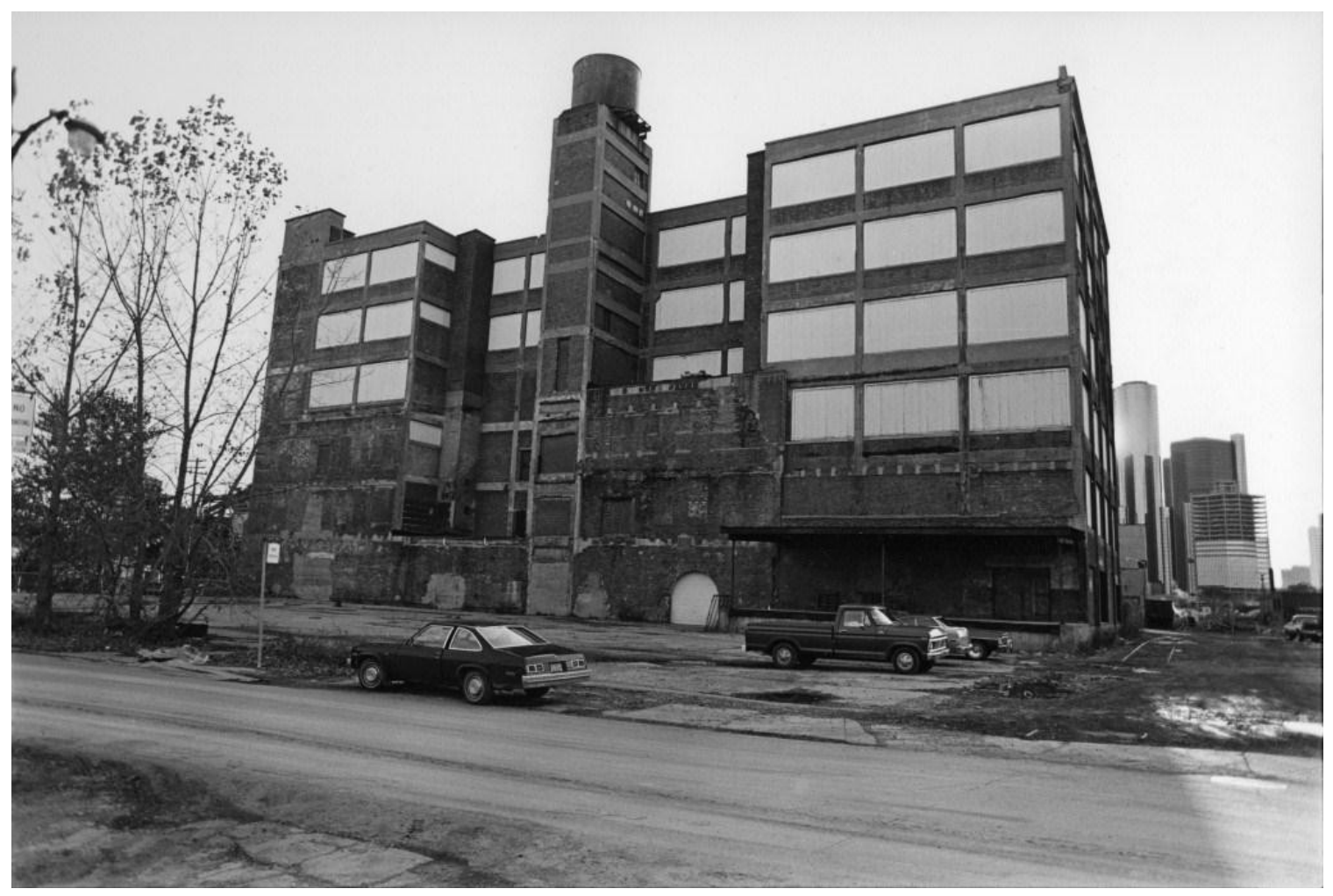

FIG. 37 DETROIT SCREW WORKS: Cassani, M. Documenting Detroit Collection. 1980. 


\title{
Chapter Two: D Build Detroit, An Architectural Proposal
}

\author{
"It is a tragedy that planners only plan and architects only design more \\ architecture. More important than the design of cities will be the design of their \\ decay." -Rem Koolhaas, 1985
}

The National Demolition Association and Salvage Yard provide a program to test ideas outlined in the previous chapters, in particular, the themes of sacred unmaking, recuperative additions and reversing preconceptions, explored previously in Chapter 3 of Part 1. The project I propose takes on a complete block in Detroit's riverfront district, bounded by Franklin, Riopelle, Rivard, and Atwater Streets.

Sacred unmaking encourages the removal and reuse of building fragments, which reinstates the cycle of creation, destruction, and reconstruction. This project facilitates a gathering area for the materials during deconstruction and before their return to reconstruction. Through public cooperation, these fragments are pulled from abandoned structures and given new life. As each fragment is taken from the whole, the meaning of the piece within its context is revealed. As the city itself is disassembled into the salvage yard, the evolution of building practices in Detroit is exposed.

Recuperative additions facilitate the progression of deconstruction into reconstruction by providing a condition in which the past is recouped and can live once again. Through a strategic and well-considered intervention, new elements act as stimulants, making sense of the old layered fabric and building remnants and rejuvenating them. Criteria for these new elements are: renewed life of the block 
and district from an urban planning standpoint and clearer relationships with adjacent neighborhoods. From the downtown, to Lafayette Park, and the Dequindre Cut, to the waterfront, the project must make the block in question perform more actively in this network.

Reversing preconceptions challenges ingrained notions of urban planning and architecture in order to expose the shortcomings of our current system. By introducing programs and material pallets that are unconventional within the context of the urban environment the project can transform the attitudes of the community and influence a shift in our built environments.

\subsubsection{Palimpsest}

The block is designed to activate the historic memory of the place. The plan's decisions, massing, and heights are informed by traces on the site, uncovered through the study of Detroit Sanborn Maps (FIG. 38), Baist Real Estate Atlas (FIG. 39), physical scarring on the landscape visible from satellite imaging (FIG. 40) and site visits by author ${ }^{93}$. The Sanborn Maps were created for fire insurance documentation and indicate built form, material types, and streets over an extended period of time. The Baist Real Estate Map, on the other hand, were more concerned with lot numbers and dividing up the land for sale, but still provide accurate rail line details and information about built form and site programs. The physical scarring on the site is not visible from the ground, but aerial photography clearly shows the old rail lines' journey along what used to be Guoin Street.

${ }^{93}$ I visited Detroit and the site on the $5^{\text {th }}$ of September, 2013 and the $7^{\text {th }}$ of November, 2013 
The Palimpsest (FIG. 41) is employed to retrieve historical imprints from the earlier mappings of the block and uses them as design guides. The Ise Shrine may continually renew shrines by completely rebuilding them, but they achieve permanence through the revival of identical forms. The cycle of construction, deconstruction, and reconstruction finds full meaning through its connections with the past. Using a similar understanding of life, death, and renewal, this site is crafted to collect forms of the site and utilize them in a strategic manner to resolve the programs. This approach is reminiscent of Peter Eisenman's "cities of artificial excavation" of the 1980's in which he layered historical traces and adjusted them in order to discover new meaning and potential on his site. "The different historical layers and shifts could be understood as marks of intelligence or glimpses of the way a culture organizes itself. In this sense, architecture becomes the intervention into and the invention of stories, and this project represents a story about Long Beach that is different from those which have spoken for it previously." 94 The design of D-Build Detroit takes select traces of the site to inform the new design according to past success and adjusts them to suit the present, transforming the site into a reconstruction of the past. Instead of retelling old stories of the past, D-Build Detroit's revivals are symbolic of the natural cycle that leads to reconstruction. This project, rooted in the past forms of the site, achieves an eternal existence through perpetual renewal instead of tangible conservation.

\footnotetext{
${ }^{94}$ Peter Eisenman. Cities of Artificial Excavation: The Work of Peter Eisenman, 1978 - 1988 (New York,
} NY: Centre Canadien d'Architecture and Rizzoli International Publ., 1994) 175- 176. 

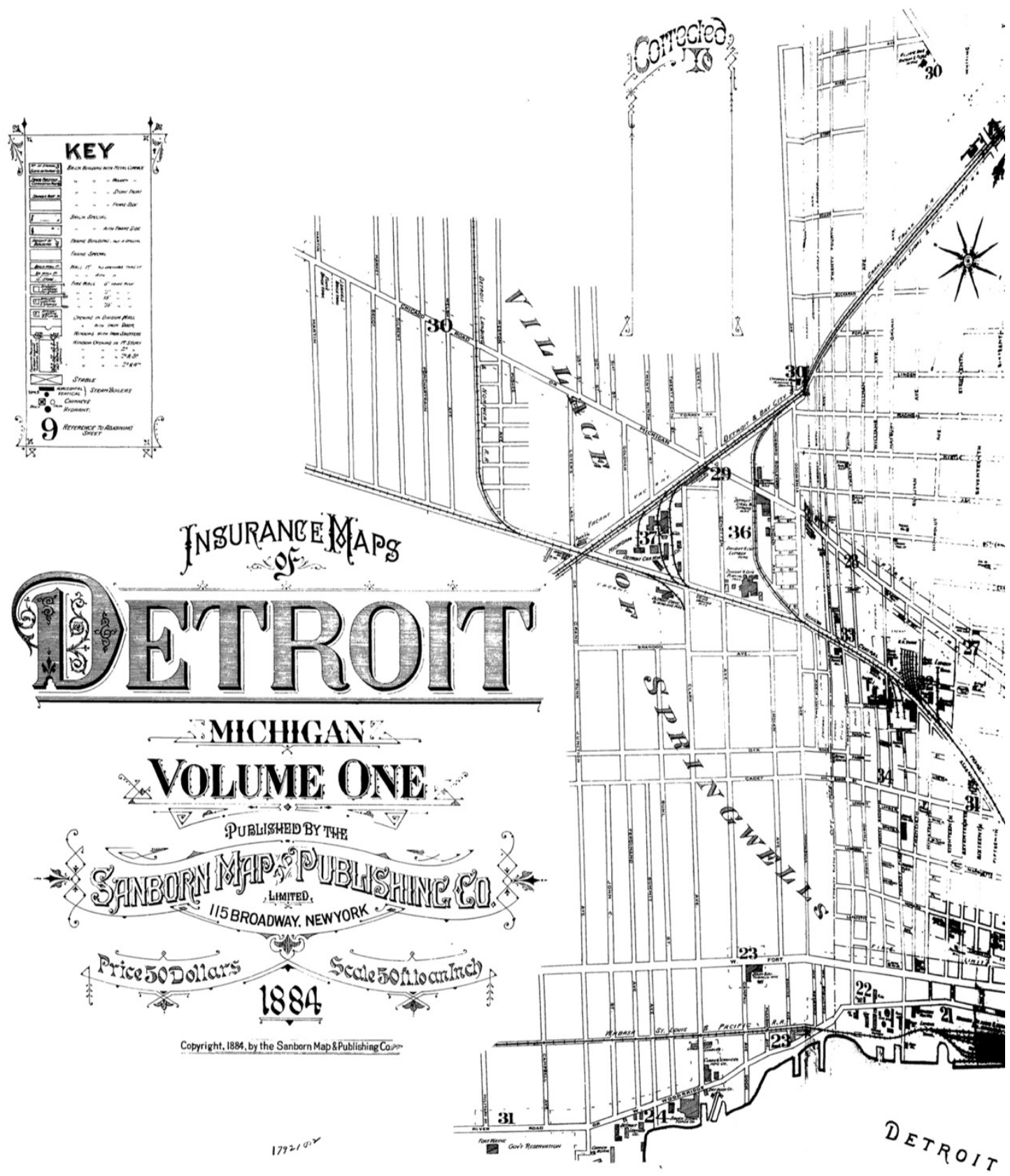

FIG. 38 SANBORN INSURANCE MAPS OF DETROIT VOL. 1: Burton Historical Collection, 1884. 


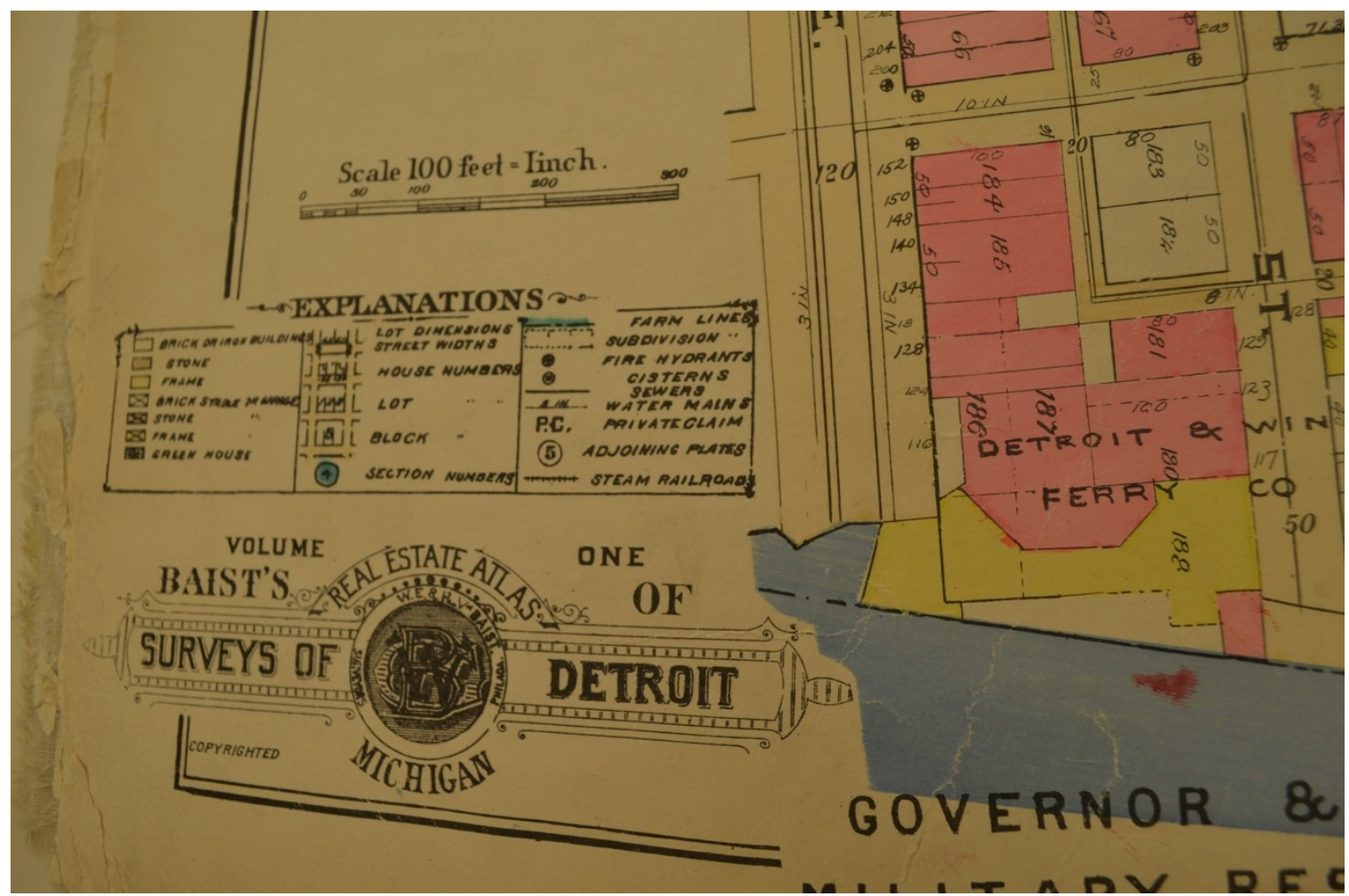

FIG. 39 BAIST’S REAL ESTATE ATLAS, SURVEYS OF DETROIT VOL. 1: Burton Historical Collection, 1929.

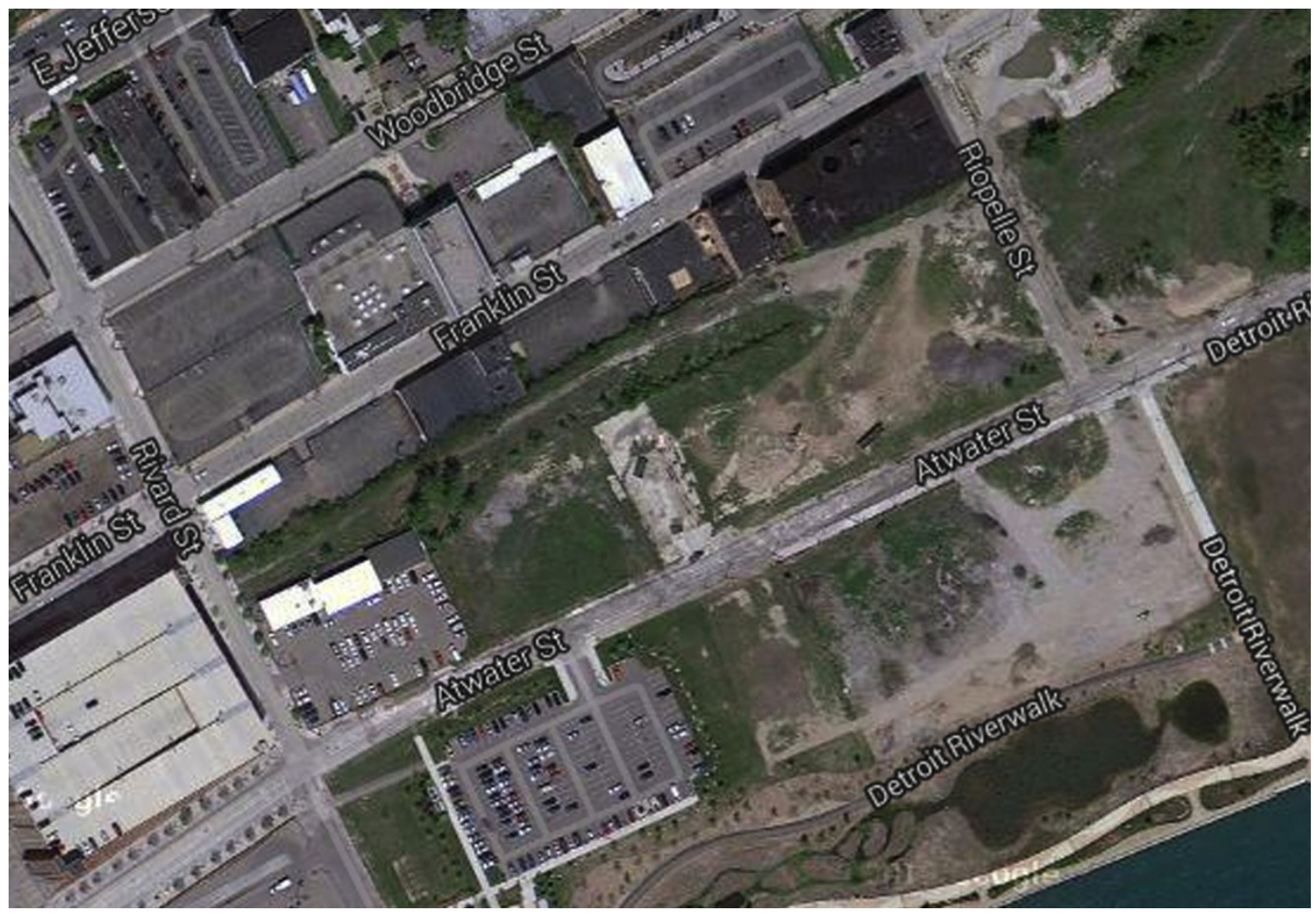

FIG. 40 DETROIT EAST RIVER FRONT: Google Maps, satellite image, 2013. 


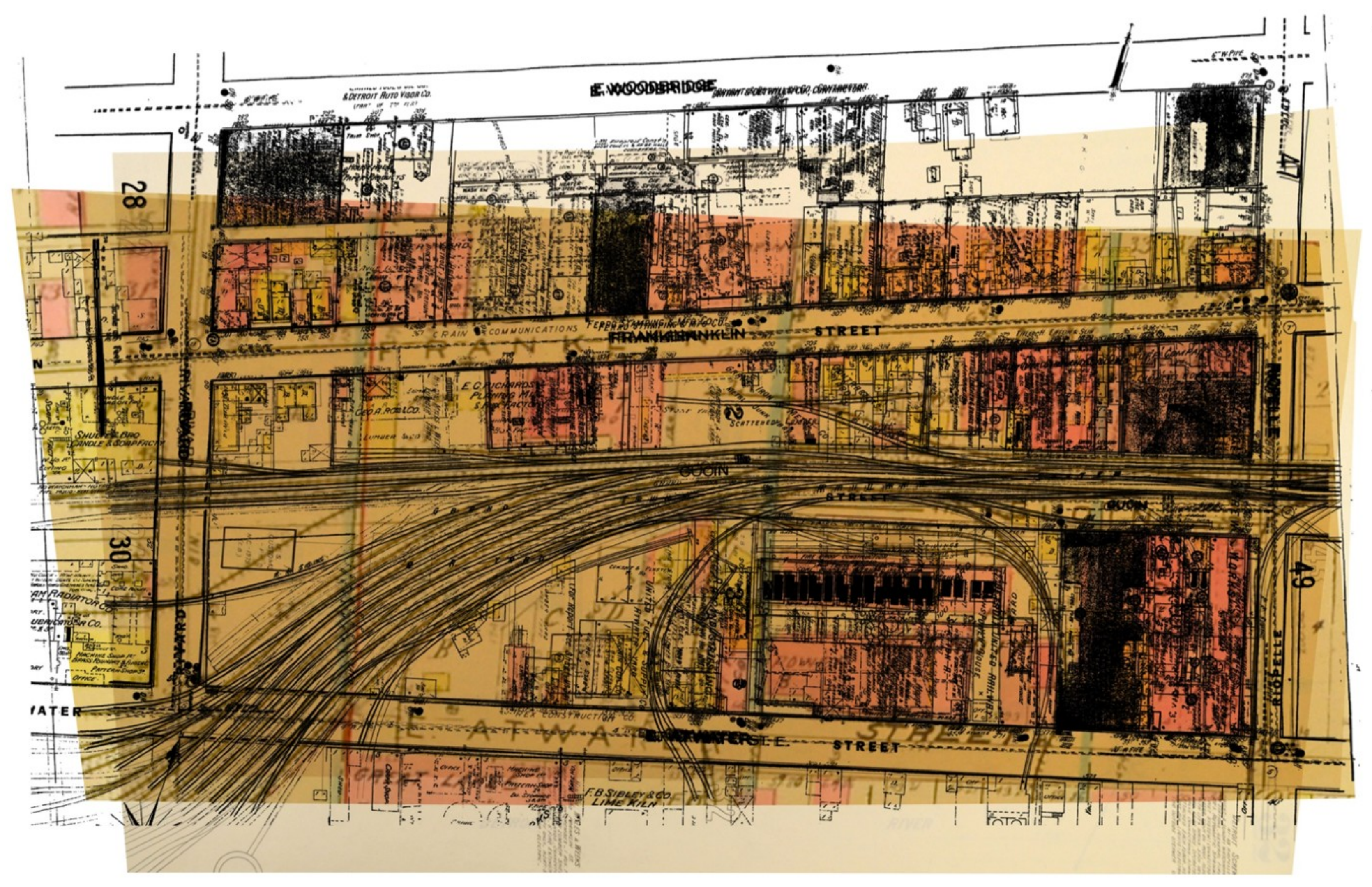

FIG. 41 PALIMPSEST OF THE SITE: McKeracher, Colleen, 2014. 


\subsubsection{Design Proposition}

The block is conceived as a center for the National Demolition Association, an existing national body representing over a thousand demolition companies in North America, that is currently housed in Doylestown, PA, a small town north of Philadelphia, in a mostly residential area, where it is not likely to gain public awareness. This thesis suggests relocating the NDA to Detroit in homage to the central role Detroit has played in the innovation of American industry but also as a tribute to the city's courage in facing the numerous demolitions that have occurred during the city's demise. Relocating the NDA headquarters to Detroit will bolster its public image and offer an opportunity to communicate the important role that the demolition industry plays in the revitalization of a shrinking city. The success of the new block will rely on strategic programming, and in the context of the new Detroit, an institutional and cultural anchor such as the NDA is both a strong endorsement for the area and a stable presence on an urban block. (FIG. 28)

The proposition organizes the block into four main elements:

1. The National Demolition Headquarters building that will offer offices and meeting rooms to support the administrative aspects of the institution, as well as an auditorium and classrooms to allow the building to function as a learning center for members. On the southeast corner of the block, at Riopelle and Atwater Street. 
2. The National Demolition Salvage Yard and Workshops are located in the center of the block, running from the northern edge of Franklin Street to the southern edge of Atwater. The entire area is contained beneath a new space frame roof. A library and a study center, a market for handcrafted artisan objects, and a cafeteria act as social spaces, welcoming the public into the space under the roof and above the salvage yard. A forecourt, which acts as a space of reflection and welcome, runs along Franklin Street, where the public is invited to leave materials or building detritus as "offerings" to the center.

3. The Detroit Demolition Hotel and garden on the western extremity of the block along Rivard Street extending from Atwater to Franklin Street. The garden gently slopes up from edge of Atwater Street, allowing pedestrian street access. The Hotel straddles the reinstated Guoin Street, creating a breezeway that permits vehicle access.

4. A commercial infill along the Franklin Street edge completes the block with a microbrewery. The existing Eaton-Clark buildings and the successful Soul Food Restaurant remain untouched on the site, as the character of these buildings and their historic significance to the area merit their survival.

This project has considered lighting as a central aspect to the design, to express the project's commitment to safe and creative nightlife in a city where large abandoned lots create insecurity and fear. 


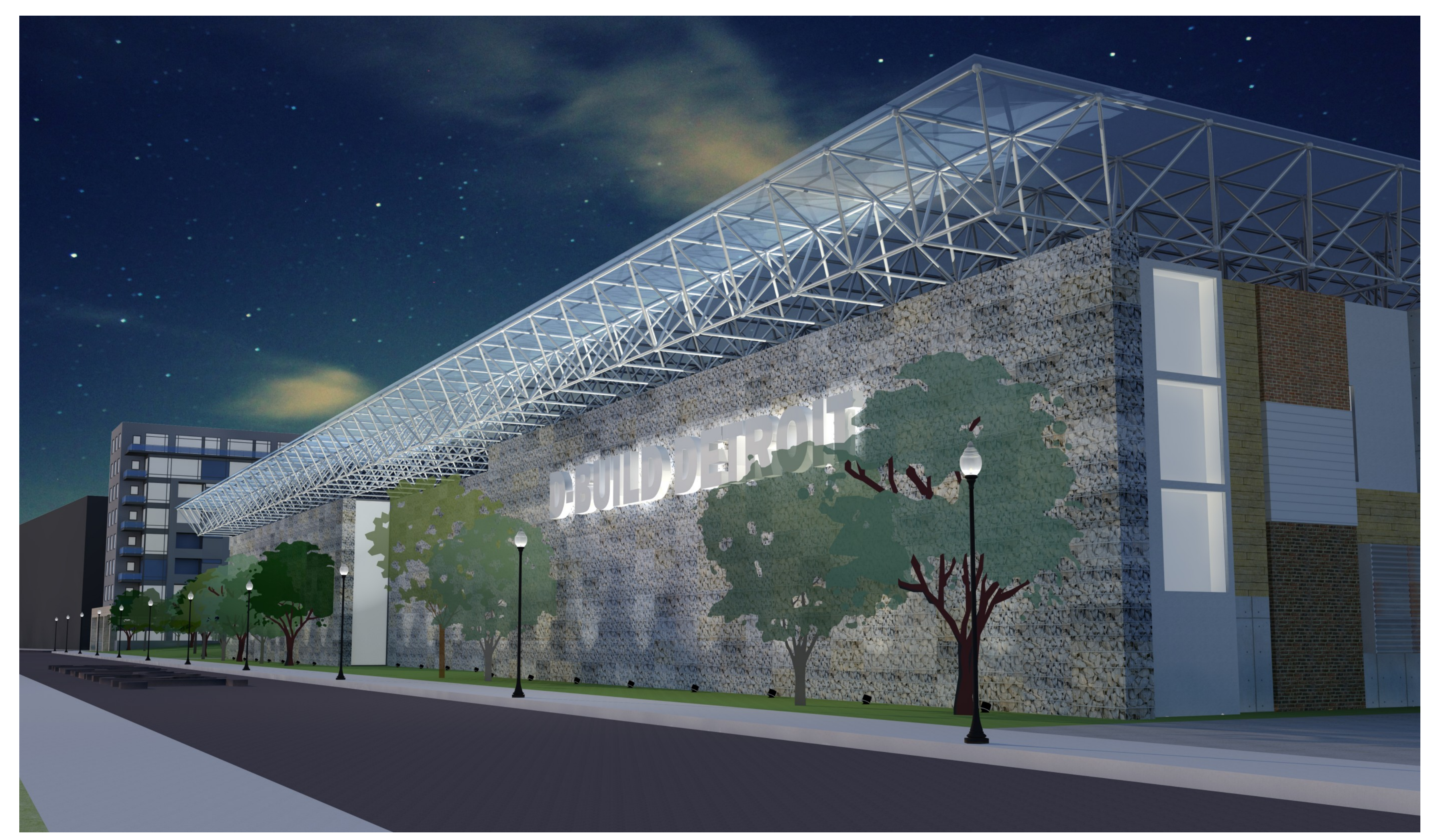

FIG. 42 D-BUILD DETROIT AT NIGHT FROM ATWATER: McKeracher, Colleen, 2014 


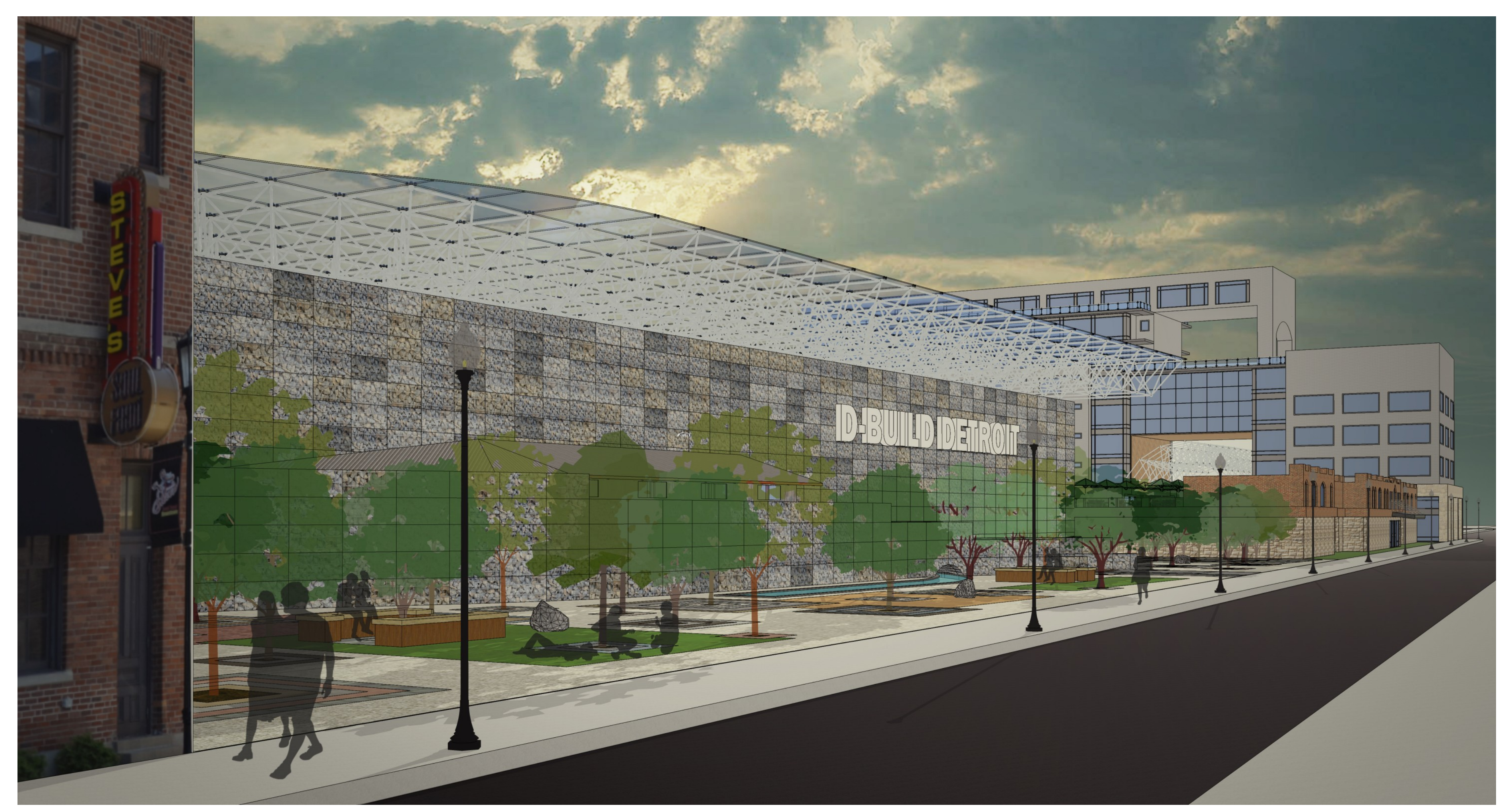

FIG. 43 FORECOURT GARDEN VIEW FROM FRANKLIN STREET: McKeracher, Colleen, 2014. 


\subsubsection{Program: List and Justification of Programmatic Elements}

The zoning for the block accepts multiple uses, and the varied program intends to create the appropriate conditions for a renewed dynamic life based on the theme of demolition, while also relying on previously successful programs in this area of Detroit, in particular, programs dealing with nightlife and music culture, and storage yards for raw materials. (FIG. 44)

1. A Headquarters for the National Demolition Association in Detroit would be a logical proposition as even though most industries in the city are experiencing decline, the demolition industry is thriving. Detroit has pride in its industries and its workers, evident within the historical murals created by Diego Rivera inside the Detroit Art Gallery that depict the innovations and toil that raised the city to the status of industrial titan. A grand headquarters for a prosperous industry is entirely appropriate, especially within the shadow of the Renaissance Center, the world headquarters of General Motors. The National Demolition Association and dedicates itself to creating an elevated standard within their industry through education, public awareness, and government advocacy. These tasks demand a large office in order to coordinate efforts and grow their brand. The NDA is working to dispel common misconceptions of the industry, such as the notion that demolition contractors do not recycle materials, and a large auditorium would provide the Association with a forum to discuss their efforts towards improving salvage and waste management. The association already has many online 
features for interacting with the public, such as a gift shop and contractor directory, and a physical setting for these outreach activities would be beneficial. The physical manifestation of the Demolition Academy would expand on the existing educational seminars concerning site and operations safety, legal issues, and management training. A personal connection between the students and the teacher will increase the learning potential as well as increase interest in the study of demolition. An active network of educators who share ideas and discuss new demolition strategies will help to build a knowledge base within the demolition community.

2. The salvage yards provide a place to collect and recover building fragments from old Detroit. As a storage facility, a salvage yard protects fragments that still hold value and need to be held in the interim between their old life and their revitalization. Historically this block held yards for lumber, pipes, cotton, iron, steel, and cut stones. The site's proximity to the train depot provided an ideal location for the storage of raw materials and the salvage yard recalls this function of the site. The forecourt is a place of ritual where visitors offer architectural fragments to the salvage yards as a tribute to sacred unmaking. By endorsing a cyclical system of material use, the salvage yard promotes a spirit of waste awareness within the community.

The public features of the salvage yard include the demolition library, cafeteria, and artisan market stalls. The library would build the definitive collection of resources pertaining to demolition in the world, legitimizing the 
Demolition School as the preeminent facility for demolition studies. The cafeteria would serve office workers and visitors and could accommodate small gatherings for lunch. The stalls provide the salvage yard with an outlet for wares in the form of small crafted goods to sell to visitors. These items would be taken from the salvage yard and reconstructed or restored, ready to be brought back into use. In growing cities, non-profit organizations are working towards building new homes for families in need, while in a shrinking city like Detroit, non-profit organizations like Detroit Blight Authority and Motor City Blight Busters remove abandoned buildings for neighbourhoods in need. By providing Detroit with a salvage yard that is capable of accepting deconstructed houses, the program supports these enterprises.

The National Demolition Association would rely on the salvage yard to provide it with palpable information for demolition research purposes. Through organization and databases, the salvage yard can give insight into popular materials available for reuse and untapped potential for disassembly. A salvage yard would serve as an experimentation ground. Material behaviour and deconstruction techniques can be understood intimately, fostering further innovation within the industry.

3. A hotel is a suitable program for the Riverfront district given nearby amenities attracting tourism and views of the Detroit River. Numerous hotels in the area already provide accommodation for tourists but the proposed 
development for the block can expect an influx of visiting professors, students, and business representatives with engagements at the NDA headquarters. An underground parking lot would serve hotel guests, securing their vehicles, which is an important feature in a city known for car theft. ${ }^{95} \mathrm{~A}$ music lounge and bar in conjunction with the hotel is an ideal place for visitors to relax, socialize with colleagues, and enjoy refreshments.

4. The Microbrewery provides a place to gather and enjoy food and libations. There is a long tradition of nightlife that once thrived in the Rivertown district even during the city's most economically depressed times, such as the Soup Kitchen, Rhinoceros Club, BC's, and the Franklin Street Brewery. ${ }^{96}$ These clubs were forced out of the area in 1998 when a controversial effort by the city to build three casinos in the area, effective left the area abandoned and devastated after the city bought or condemned 52 acres of the East Rivertown area. ${ }^{97}$ Now that casino proposals in this part of the city have been dismissed, there is an opportunity to restore the nightlife tradition and once again populate the area.

\footnotetext{
${ }^{95}$ Jim Gorzelany, "Cities With The Most (And Least) Stolen Cars," Forbes, June 26, 2013, http://www.forbes.com/sites/jimgorzelany/2013/06/26/cities-with-the-most-and-least-stolencars.

${ }^{96}$ Richard Wilson, "A History of the Detroit Riverfront," RAWblog, accessed March 23, 2014, http://www.richwdesign.com/Riverfront_History.pdf.

97 Ibid.
} 


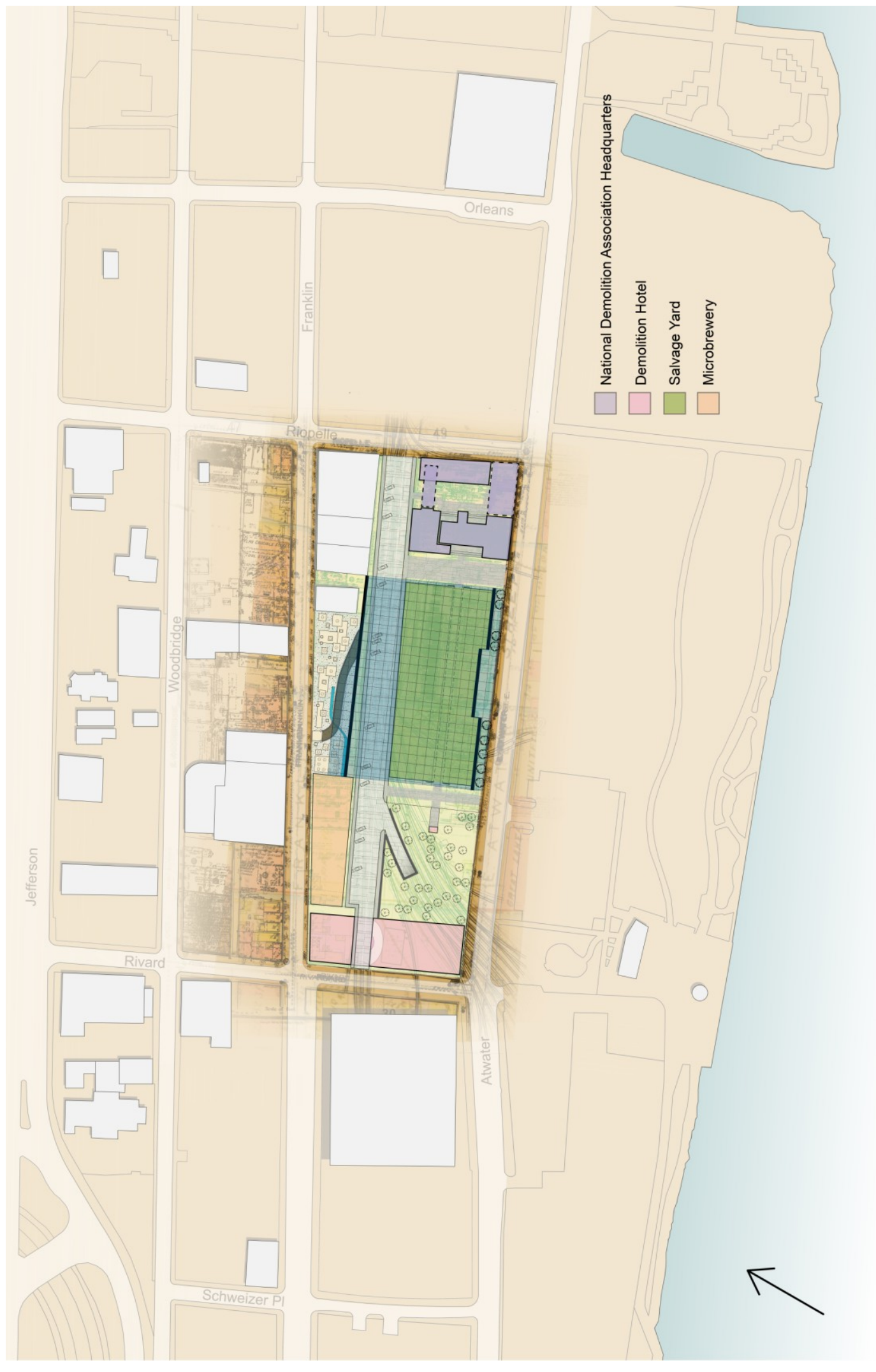

FIG. 44 SITE PLAN: McKeracher, Colleen, 2014. 


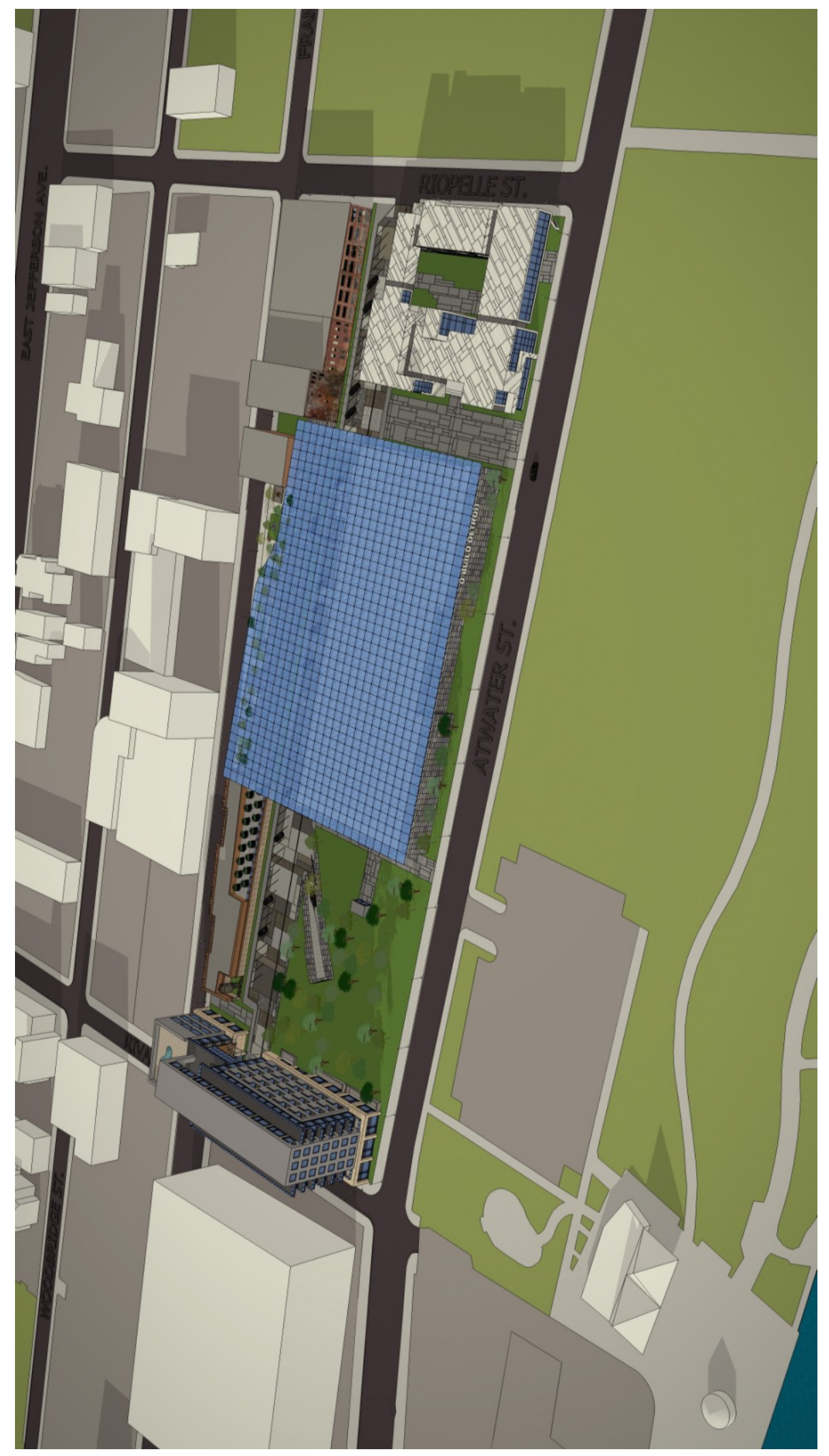

FIG. 45 OVERHEAD: McKeracher, Colleen, 2014. 


\subsubsection{Design Approach: Site Massing and Parti}

In the motor city, cars are the preferred method of transportation and this site design responds to the demand for vehicle access by reinstating Guoin Street as a roadway. Providing vehicle entry points from Riopelle and Rivard Street, the traces of the old rail lines offer a wide road capable of handling large trucks and offering street parking. As the traces of the Gouin Street rails diverge on the western end of the site, the roadway splits and cuts into the site, creating an entrance to the underground parking below the hotel. The adjacent lot east of the block is preparing to develop a residential block and preliminary plans show the developers' intent to resurrect Guoin Street as well, which will serve to connect the site to the Dequindre Cut and create a clear relationship between the new developments.

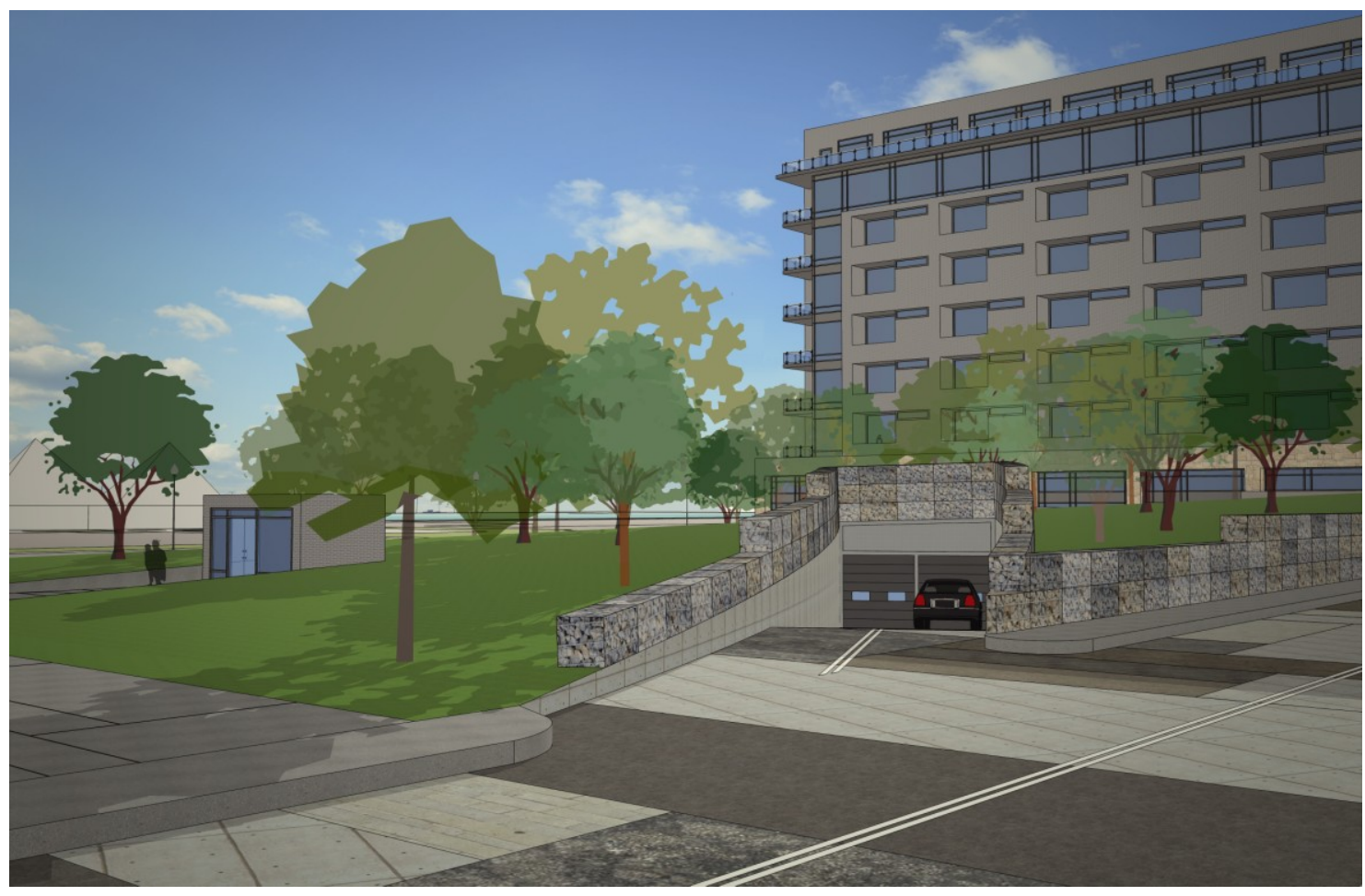

FIG. 46 VIEW FROM GUOIN TO PARKING RAMP: McKeracher, Colleen, 2014. 


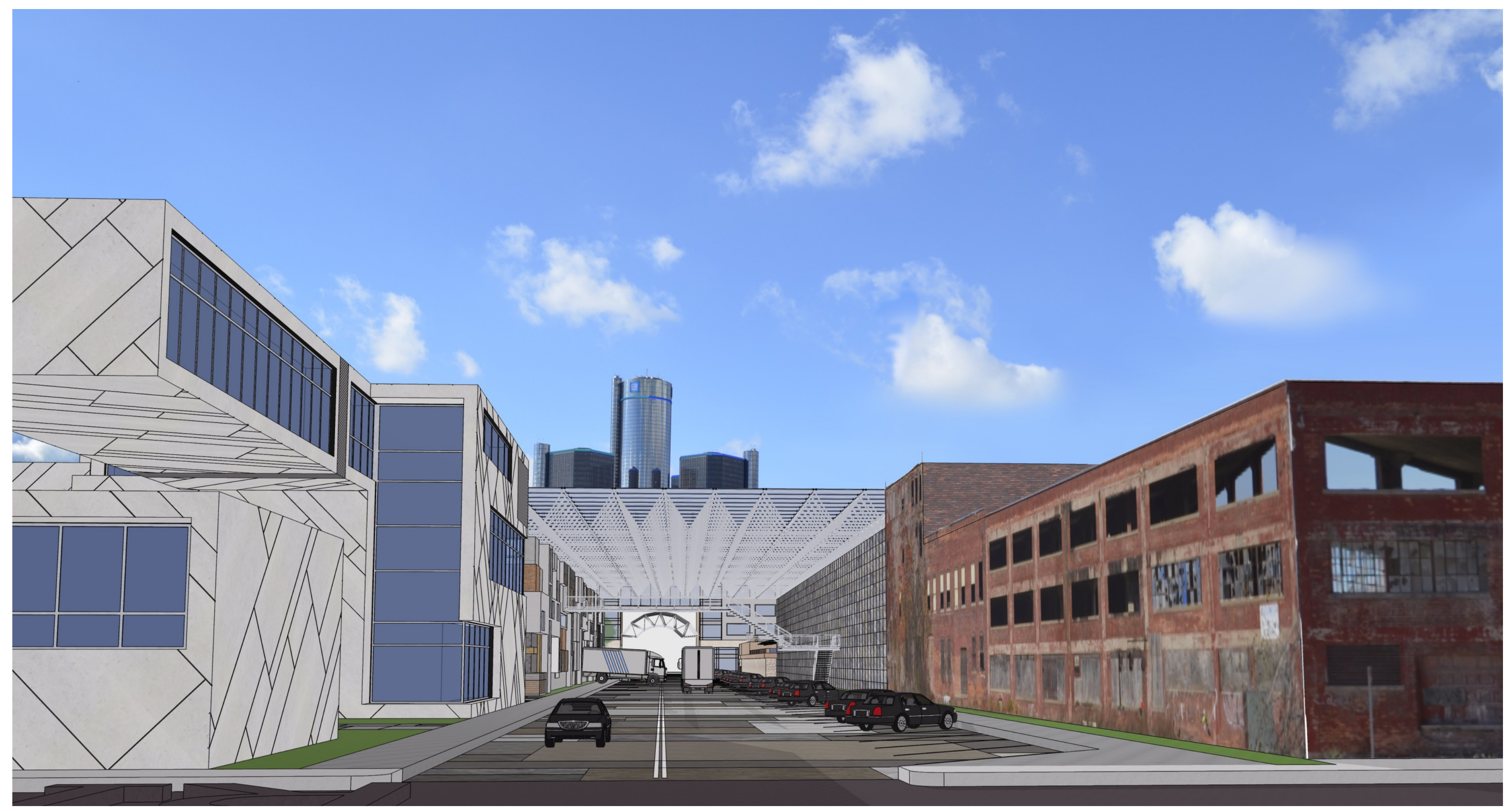

FIG. 47 VIEW FROM RIOPELLE STREET: McKeracher, Colleen, 2014 
1. The NDA headquarters recover the footprints of both the 1892 and 1912 Screw Works on the corner of Atwater and Riopelle Street. This location is highly visible to vehicle traffic and foot traffic along the RiverWalk, asserting the legitimacy of the institution and encouraging public interaction. The building's U-shape establishes a large courtyard, allowing plenty of natural light and air to permeate into the office spaces. The main entrance to the headquarters is centered along the west side of the structure and aligns with the exit from the parking garage on the western side of the site, creating a pedestrian axis through the salvage yard. Approaching from Atwater Street, the gap between the headquarters and the salvage yard, adorned with lights and plants, invites people into the site and onto the axis. A three-story limit to the headquarters will adhere to the existing precedents set out by the Eaton-Clark buildings to the north of the headquarters and the two-story proposal for the residential development on the adjacent block to the east of the headquarters. Semi-private levels on the second and third floors of the headquarters provide a quiet and secure environment suitable to offices, meeting rooms, and classrooms. The ground floor, being accessible to the public, hosts suitable programs such as the visitors' center, auditorium, and gift shop, utilizing high ceilings and large open spaces to impress and attract people.

The building is readily separated into four different sections in order to prepare it for its future demise. The joints are exaggerated using a perforated metal cover and each massing would be capable of sustaining itself if 
relocated. Even if the building never realizes this separation, by utilizing the language of architectural cut lines, the design expresses an intention of reuse and reconfiguration of the existing material. 


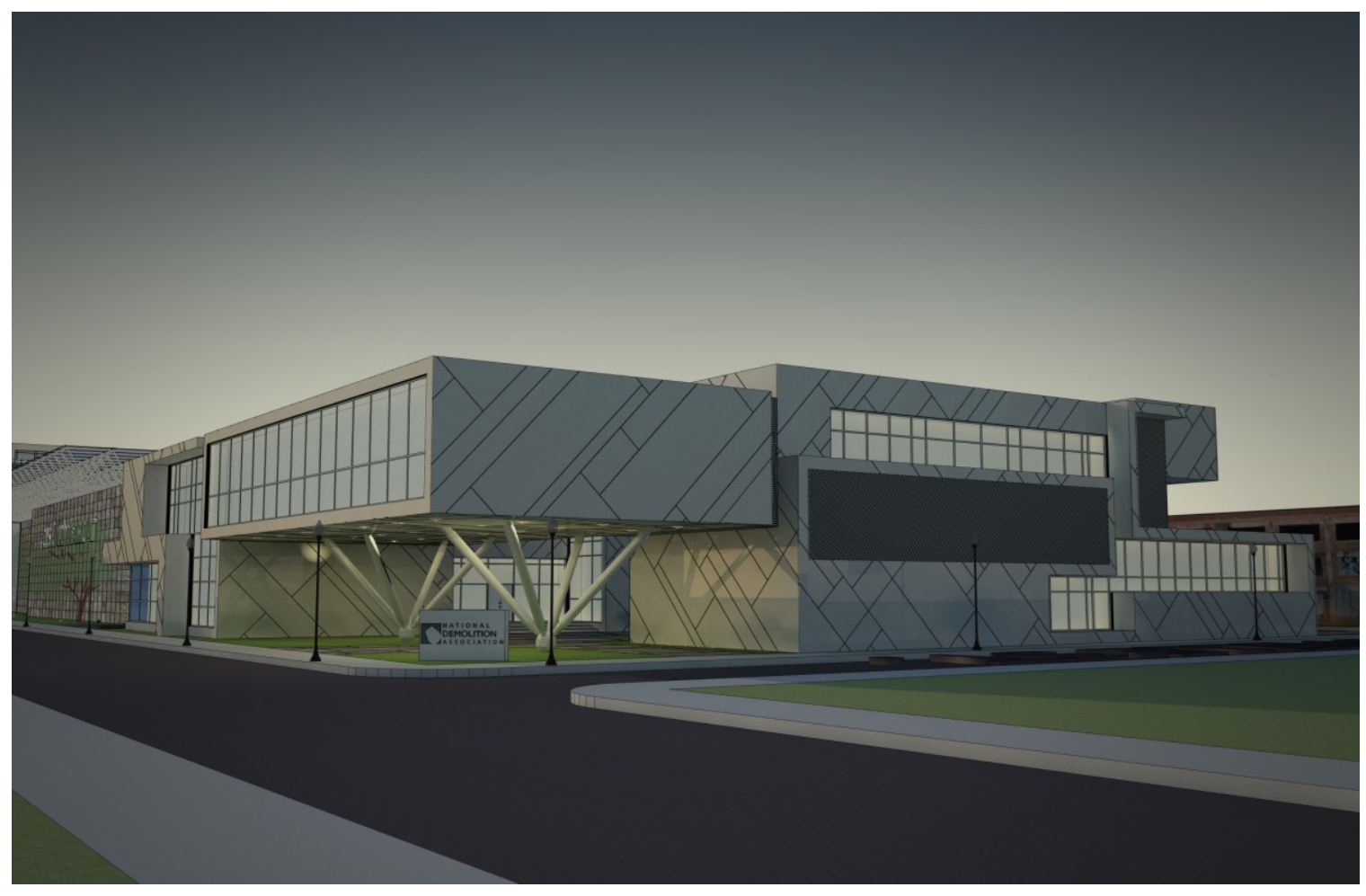

FIG. 48 N.D.A. HEADQUATERS VIEW FROM ATWATER: McKeracher, Colleen, 2014.

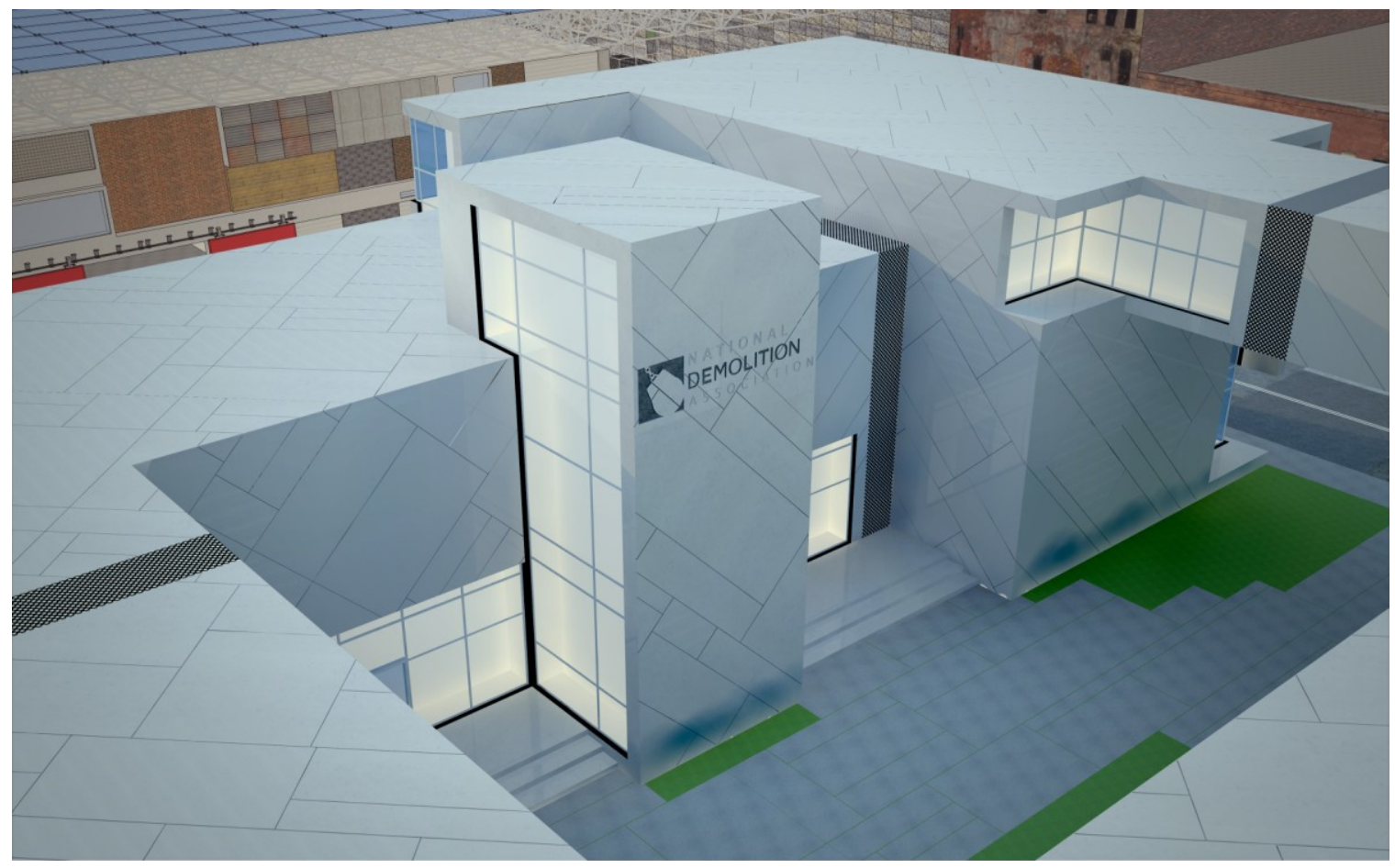

FIG. 49 N.D.A. HEADQUARTERS OVERHEAD: McKeracher, Colleen, 2014. 


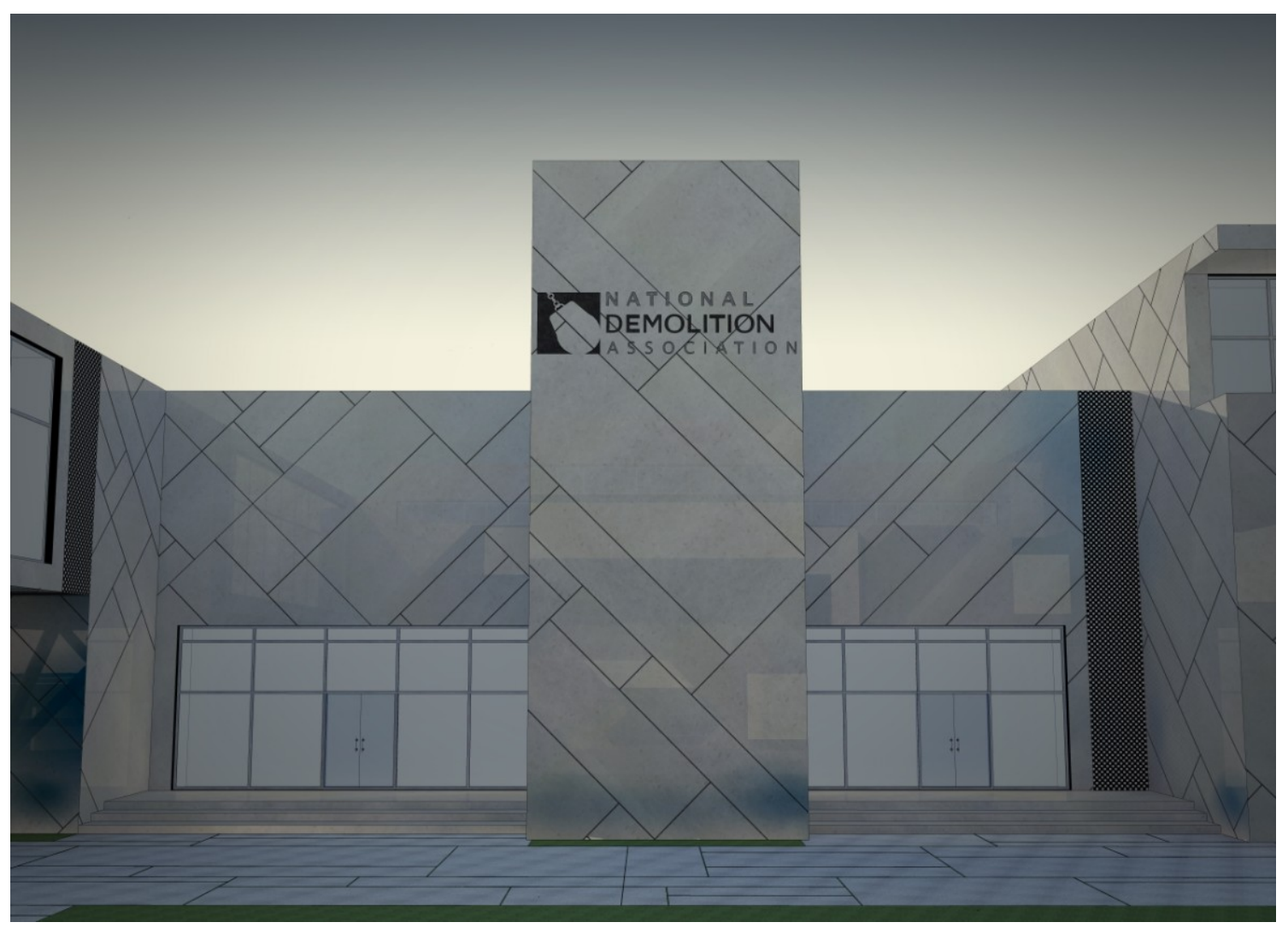

FIG. 50 N.D.A. HEADQUARTERS VIEW FROM COURTYARD: McKeracher, Colleen, 2014. 
2. The salvage yard is protected by a massive "all-encompassing" space frame roof that is stretched over the middle of the block, acting as the recuperative addition. The roof protects the ground plane and creates a setting for new elements to emerge for both the institution and the public. New elements retrieve their forms from the palimpsest and are given life once more as market stalls, benches, staircases, and paths, and the space frame roof provides structure to the elements within it. The space frame is formed using a ball joint, which is an incredibly versatile steel structure design capable of spanning vast distances. With only two components, the tubular members and ball shaped joints, the space frame is a simple construction that is capable of being reassembled in a variety of forms. The uniform component sizes simplify the disassembly process and the materials are easily transported for future uses. A glass roof brings sunlight into the site and buildings below while protecting the salvage yard against the harsh extremes of Detroit's climate. The roof is supported by two gabion walls that are filled with concrete rubble produced by demolitions of nearby structures. The modern characteristics of the slick metal and glass are sharply contrasted to the crude formation of gabion walls. The southern gabion wall extends alongside the sidewalk of Atwater Street, creating a sheer face for the entire length of the roof structure, while the northern gabion wall borders the northern edge of the new Guoin Street and also extends for the length of the roof. Taking up almost half of the site, right in the middle of the block, the roof becomes the prominent feature of the site and the gabion wall's massive 
street frontage could be used as an opportunity for signage. (FIG. 58) As different buildings begin to come together, the disassembled city appears.

A forecourt welcomes visitors from Franklin Street into the site, bounded by the existing restaurant, the new microbrewery and the northern gabion wall. This outdoor area is covered with white gravel and incorporates water features, creating the effect of a serene, ritualistic garden, where visitors are invited to drop off old building fragments and journey into the salvage yard by a curving path that slopes upwards and cuts through the gabion wall. The cut in the gabion wall is tall, thin, and angled to the wall so as to conceal the other side. The path continues, suspended, over Guoin Street and underneath the space frame roof, bringing the visitor to an entrance on the second level. In this large enclosure below the space frame roof, south of Guoin, are housed artisan market stalls and a cafeteria. The second floor is a busy area, with opportunities to shop, dine or watch the activities of the salvage yard operating on the ground floor. By completely separating the public and the institution, the salvage yard is able to operate safely and efficiently, but views down to the yards still give the public a sense of connection with the revitalization of old, lifeless fragments. The artisan stalls will further this connection with the public as they act as the salvage yards outlet to expend restored or rejuvenated materials. The third level of this enclosure contains the library, a component of the Demolition School, which is also open to the public. The library provides a quiet, protected space with views onto Guoin and the activities of the salvage yard. The façade of 
this building is designed according to the function of the building, with plenty of windows on the third floor to provide light for reading in the library, while at the ground floor level, metal and stone panels will be durable enough to sustain industrial activities. A patchwork pattern created on the façade with a variety of square and rectangular forms give a rhythmic order to the building, but without the severity of a grid, which would conflict with the diverse nature of the salvage yard. 


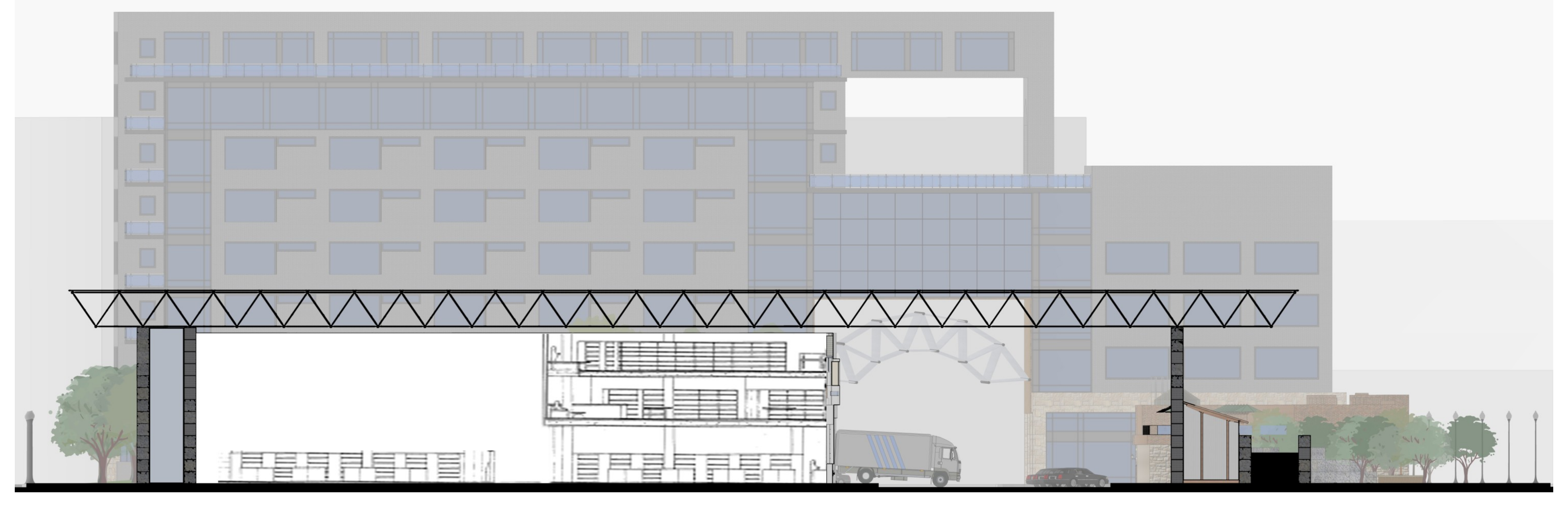

FIG. 51 SALVAGE YARD SECTION: McKeracher, Colleen, 2014. 


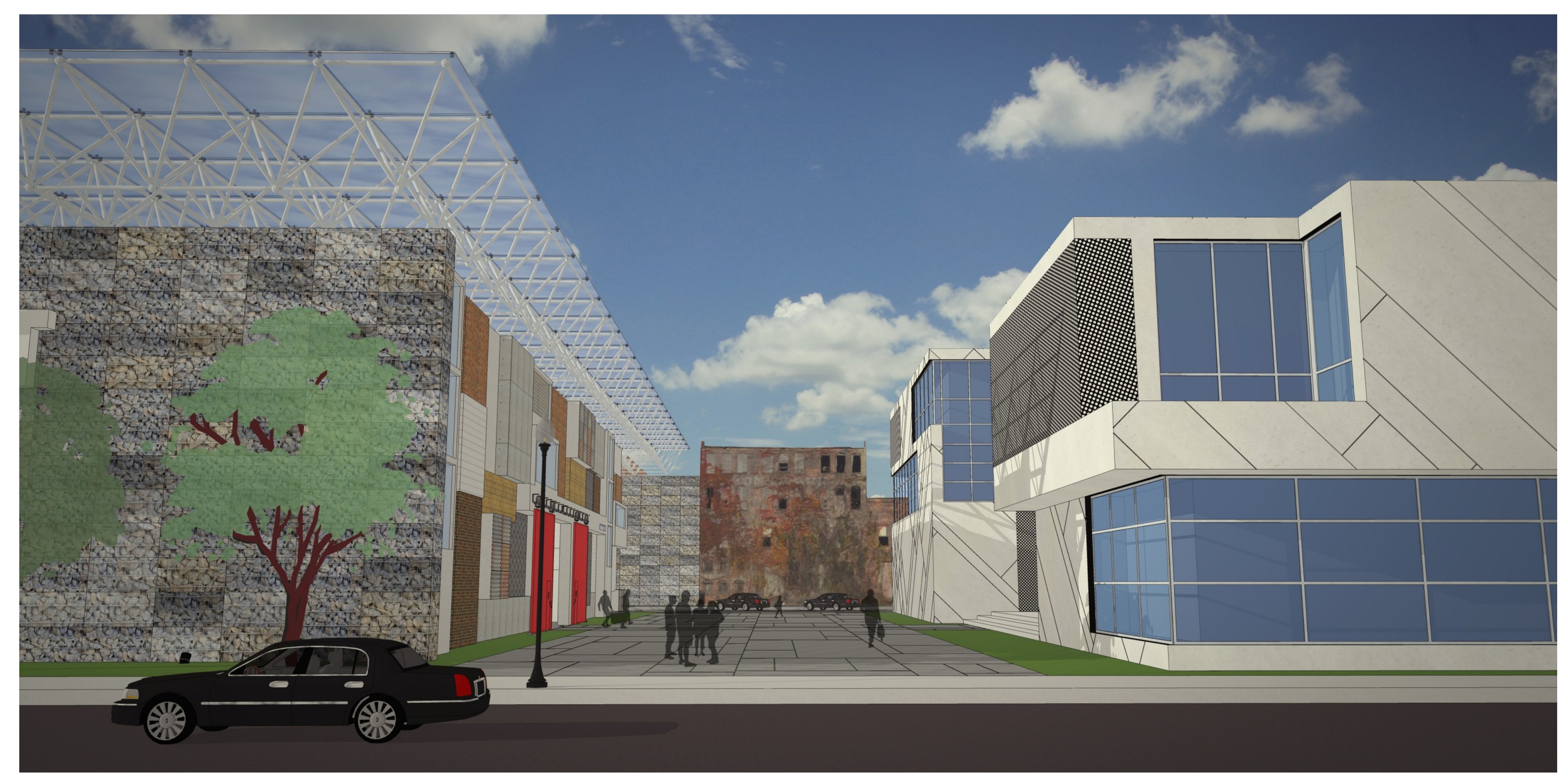

FIG. 52 SALVAGE YARD VIEW FROM ATWATER: McKeracher, Colleen, 2014. 


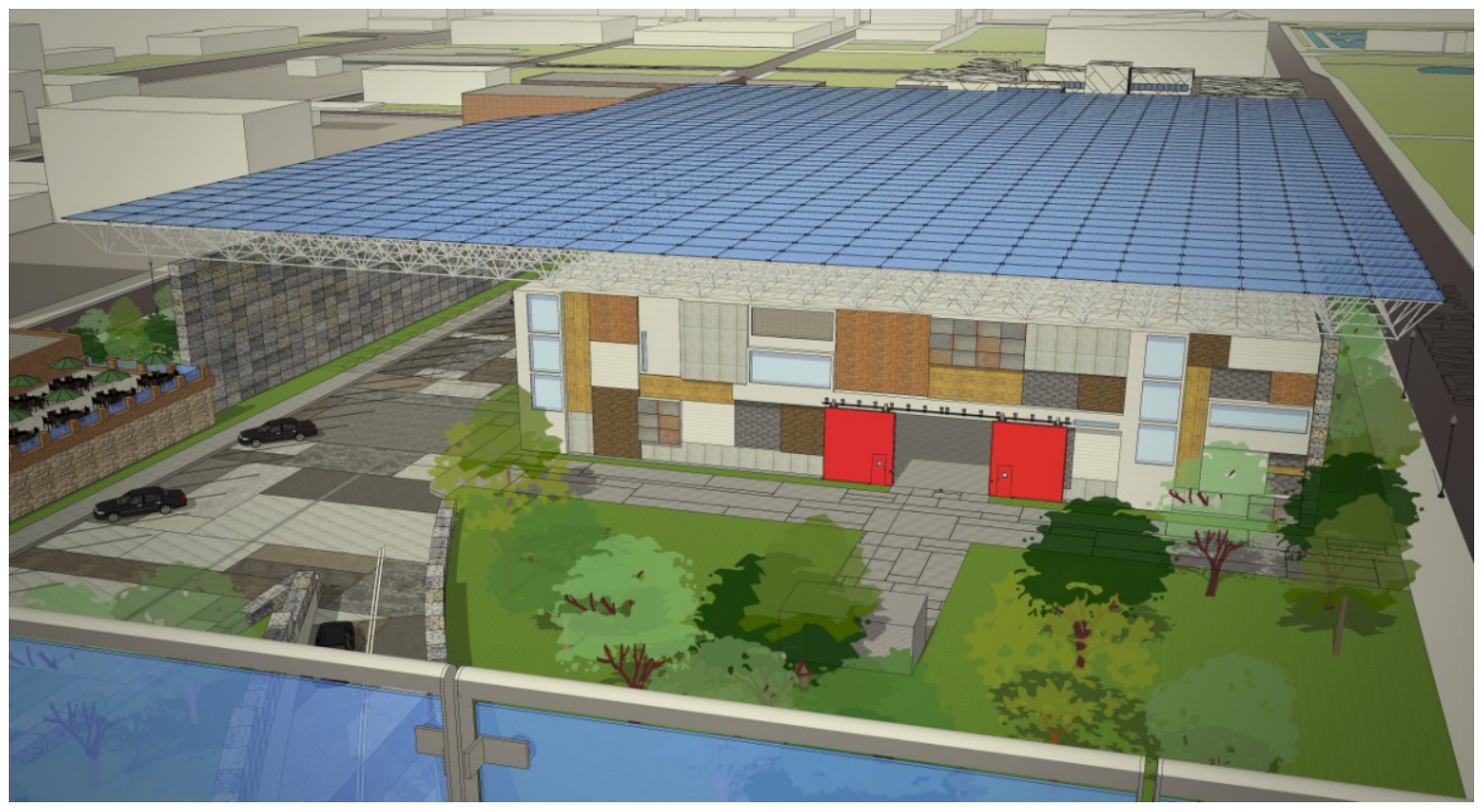

FIG. 53 SALVAGE YARD VIEW FROM HOTEL BALCONY: McKeracher, Colleen, 2014.

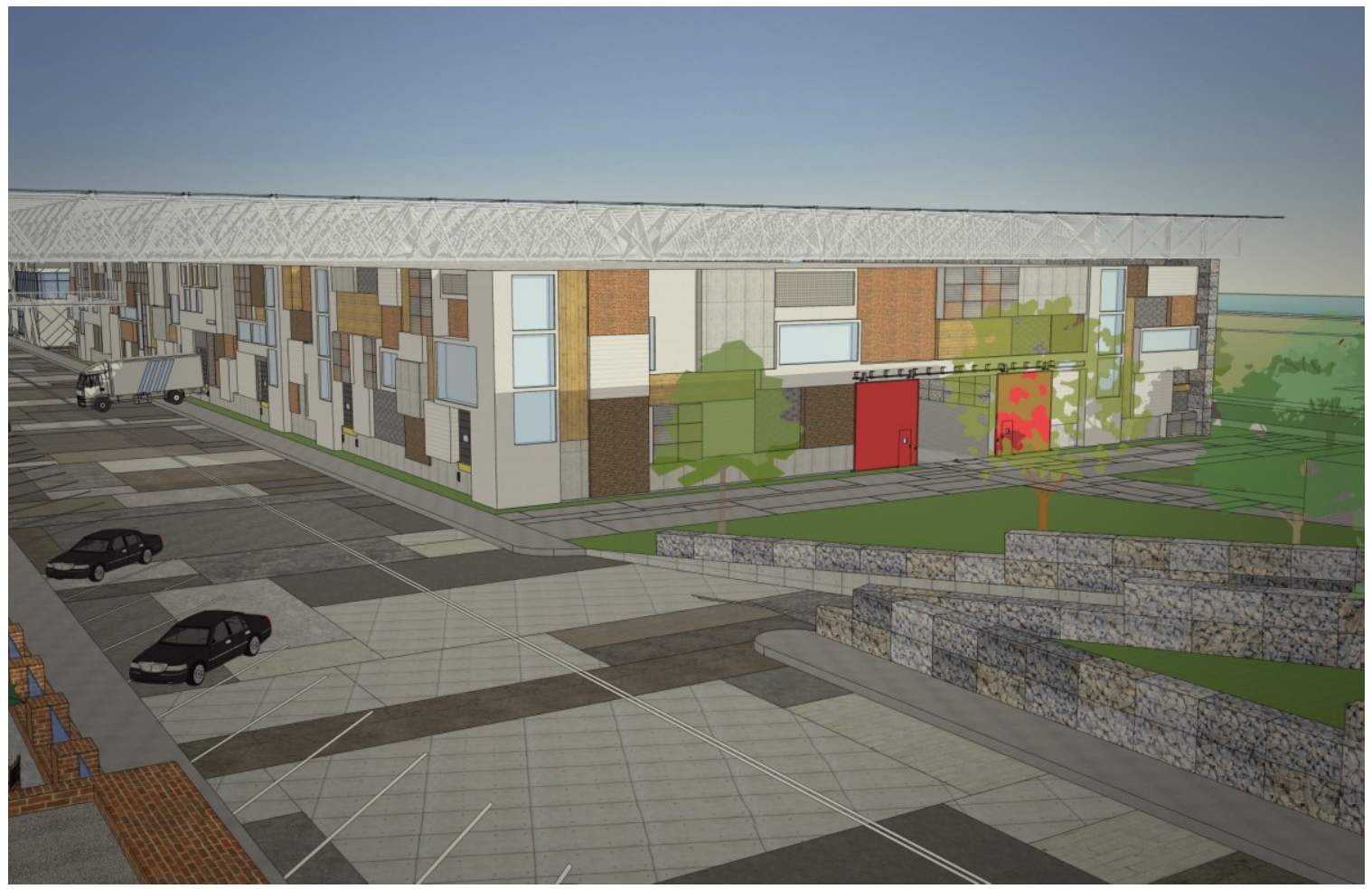

FIG. 54 SALVAGE YARD VIEW FROM GUOIN: McKeracher, Colleen, 2014. 


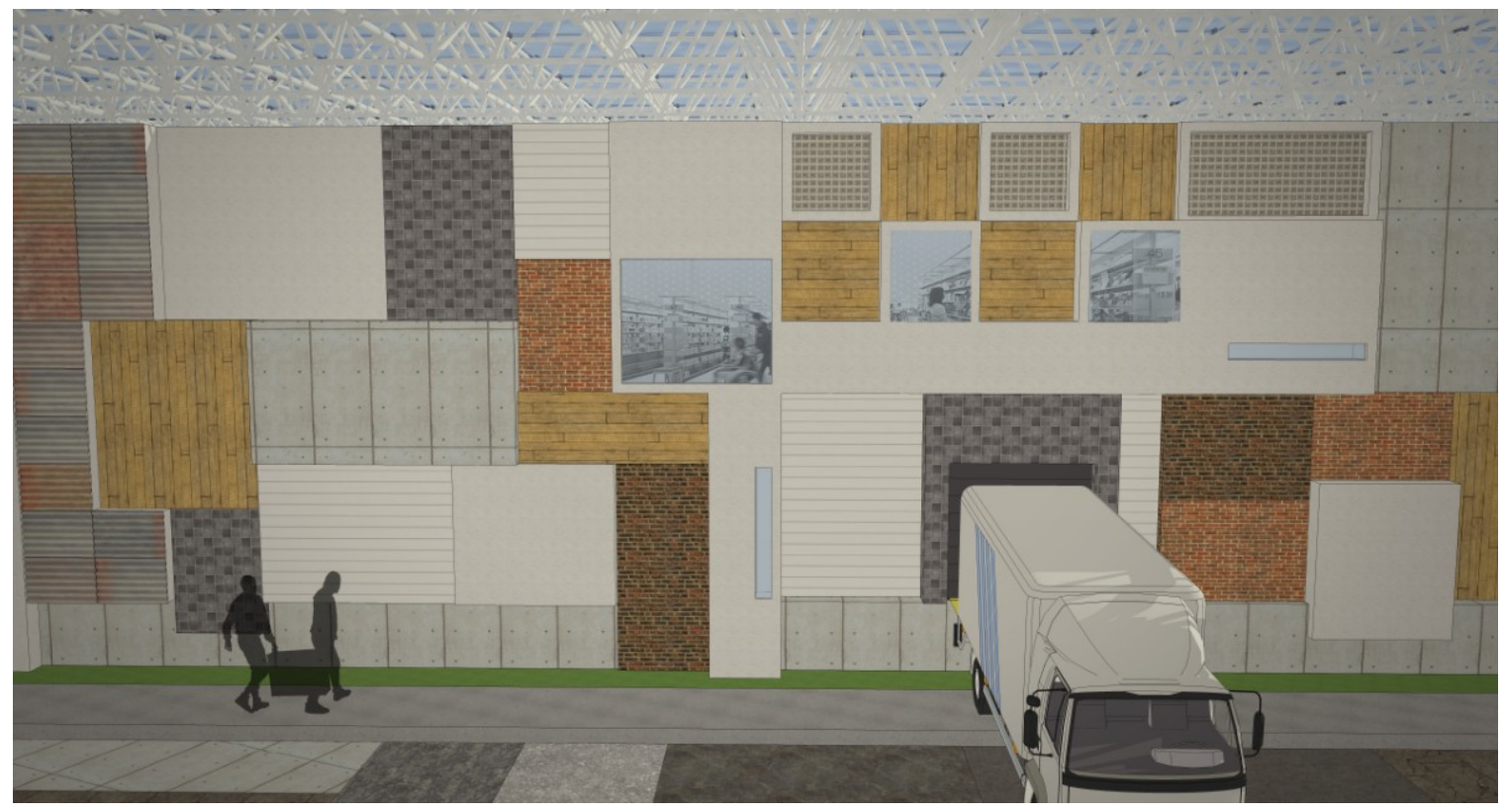

FIG. 55 SALVAGE YARD NORTH FACADE: McKeracher, Colleen, 2014.

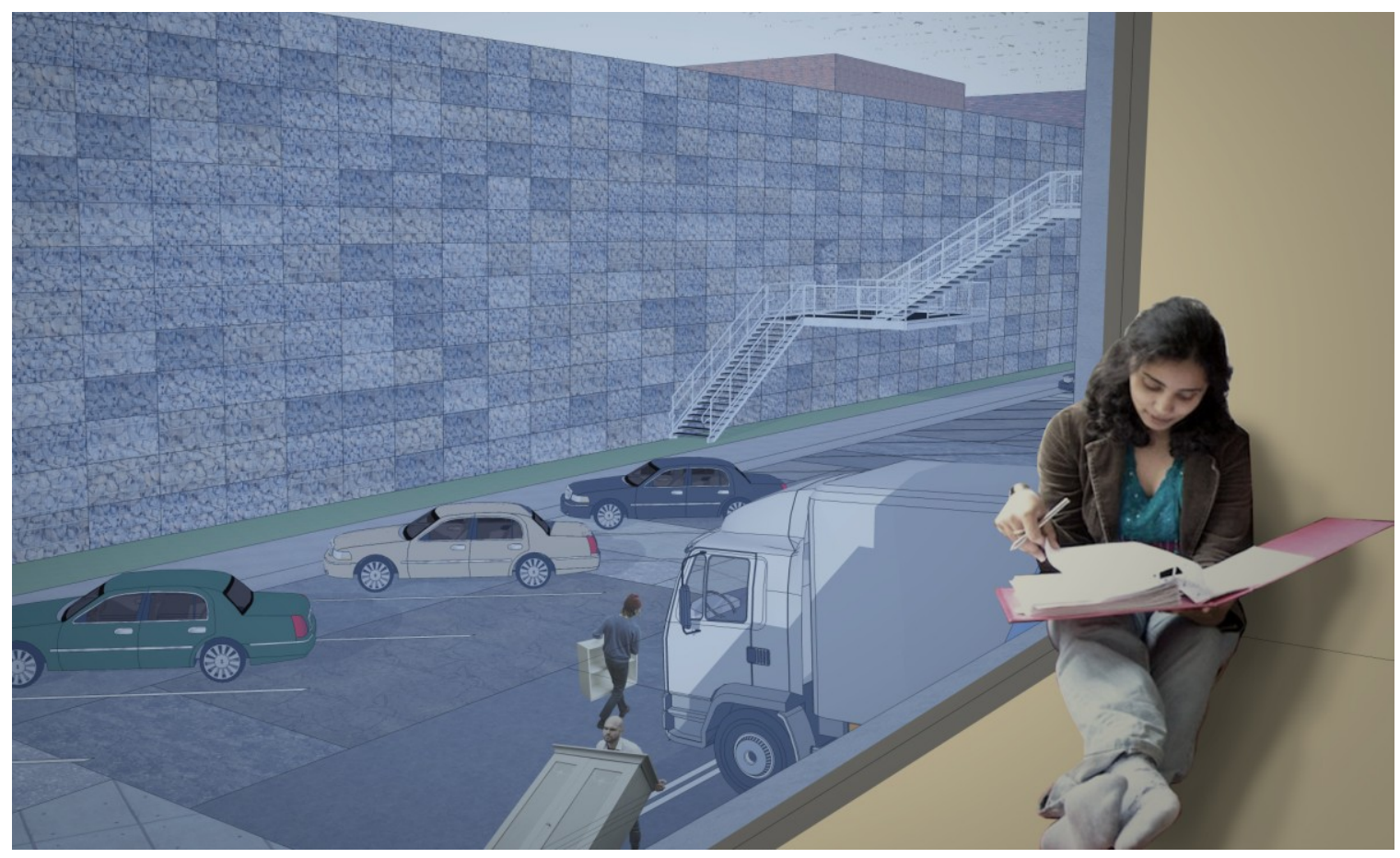

FIG. 56 SALVAGE YARD VIEW FROM LIBRARY ONTO GUOIN: McKeracher, Colleen, 2014. 


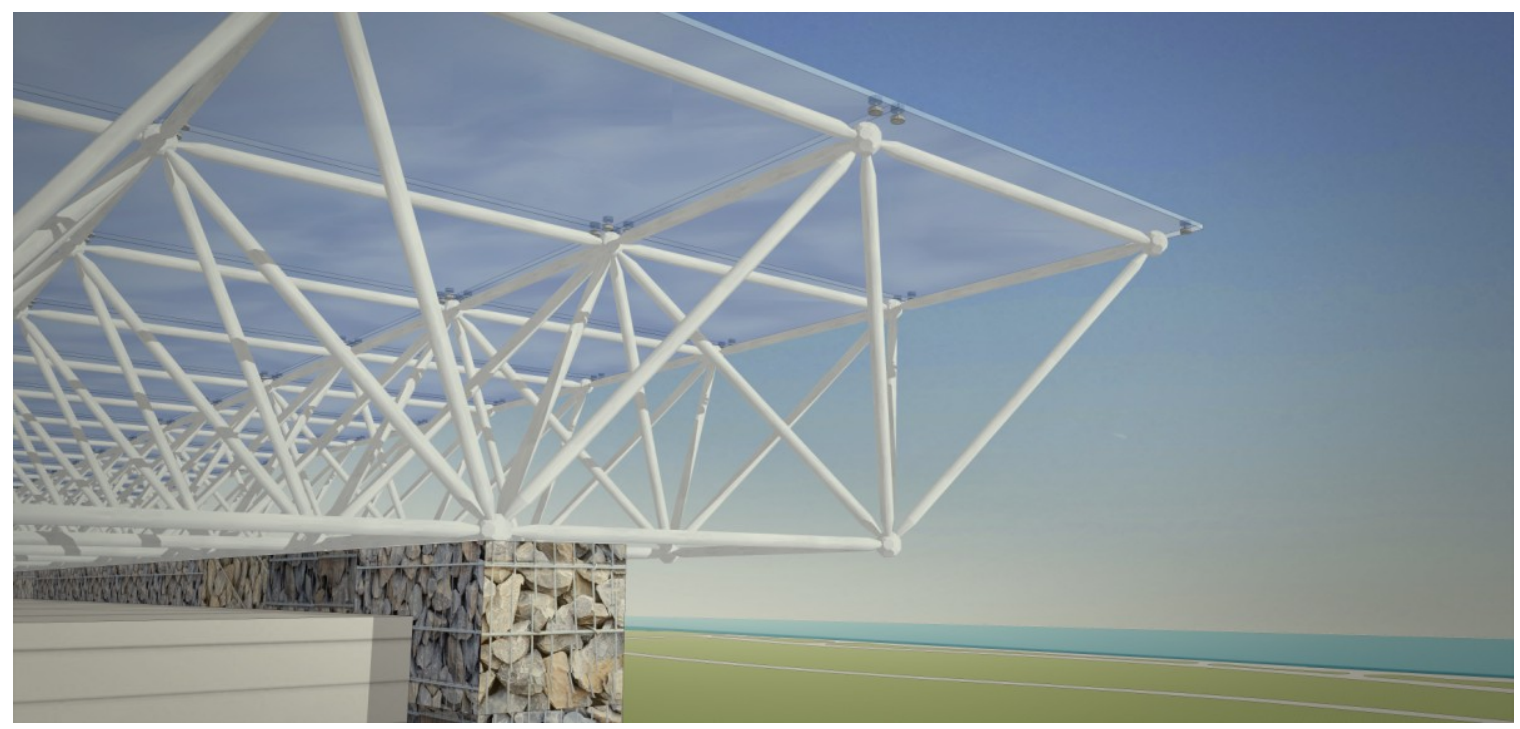

FIG. 57 SPACE FRAME ROOF: McKeracher, Colleen, 2014.

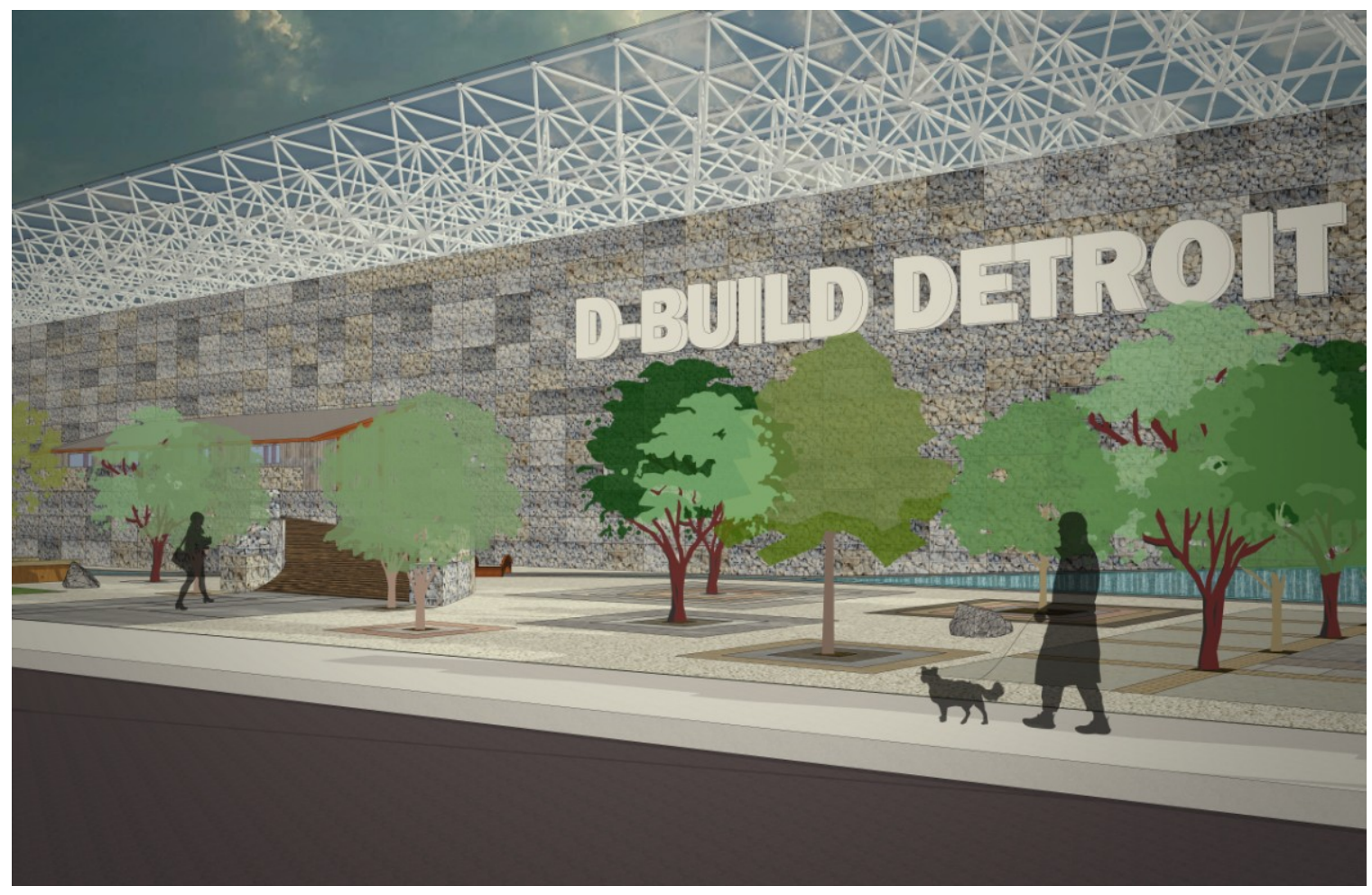

FIG. 58 FORECOURT GARDEN VIEW FROM FRANKLIN STREET: McKeracher, Colleen, 2014. 


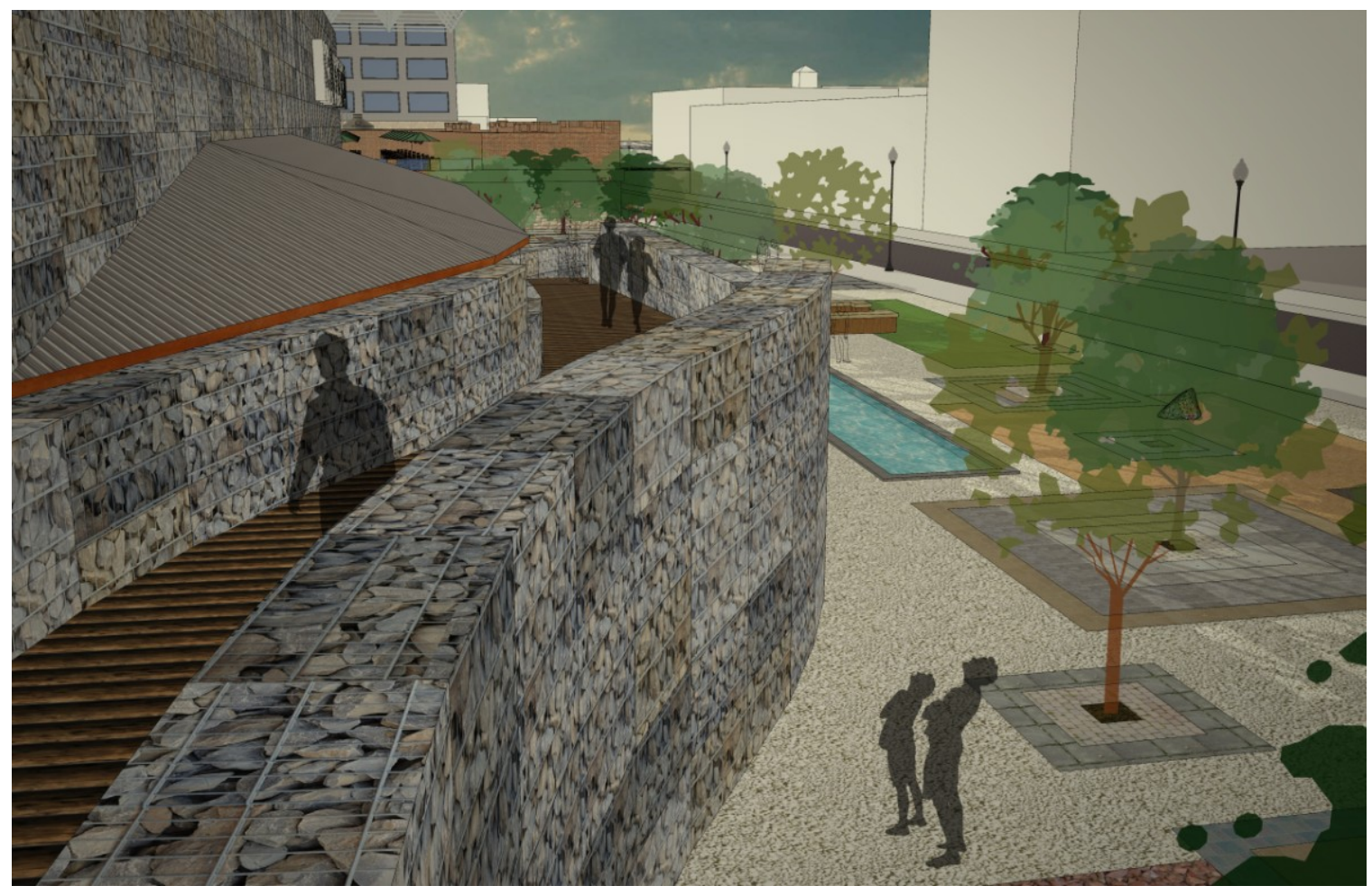

FIG. 59 FORECOURT GARDEN VIEW FROM GABION WALL: McKeracher, Colleen, 2014.

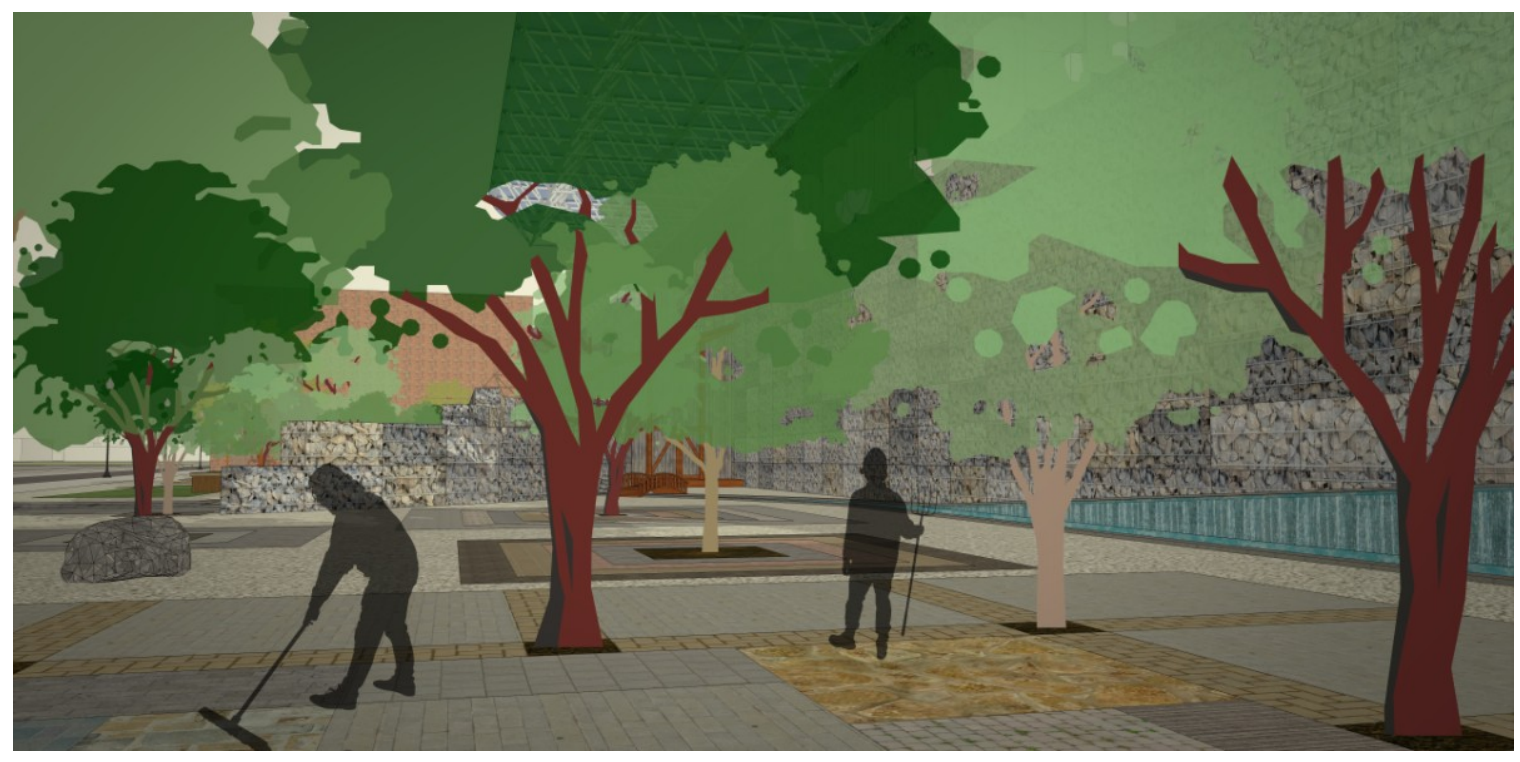

FIG. 60 FORECOURT GARDEN: McKeracher, Colleen, 2014. 


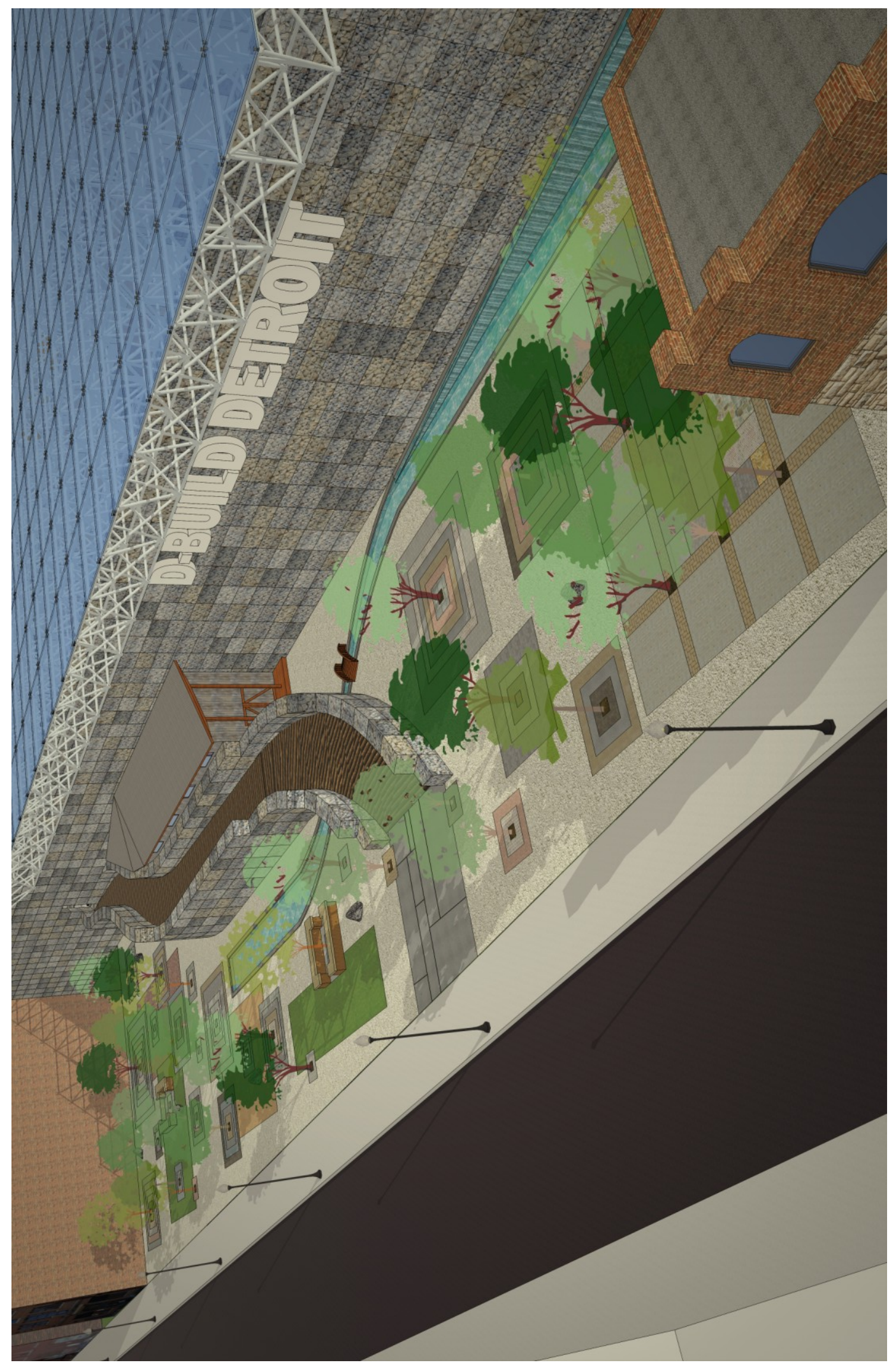

FIG. 61 FORECOURT GARDEN OVERHEAD VIEW: McKeracher, Colleen, 2014. 
3. The hotel element deviates from restrained forms of the other site elements in order to capture the grand elegance of Detroit's historic hotels such as the Westin Book Cadillac Hotel and Roberts RiverWalk Hotel, where brick and cut-stone are formed in the style of the Italian Renaissance to create classic elegance. Common elements often found in these hotels, such as portecocheres, corner lounges, and opulent double height lobbies, are captured in this new design. A porte-cochere is formed over Guoin Street to create the main entrance to the hotel lobby and provide shelter for guests arriving by vehicle. To the south of the porte-cochere is the lobby, centered on the building and opening up to the atrium, which is aligned with nine floors of rooms. The lounge, north of Guoin Street, combines a music club, bar, and restaurant, in an establishment adorned to attract high-end clients. The hotel is ten stories tall, just exceeding the neighbouring eight-story parking garage on the west side of Rivard Street, establishing dominance while at the same time not obliterating the height precedents in the area. The garden slopes gently up from Atwater Street, making the area highly accessible for pedestrians and concealing the underground parking lot. 


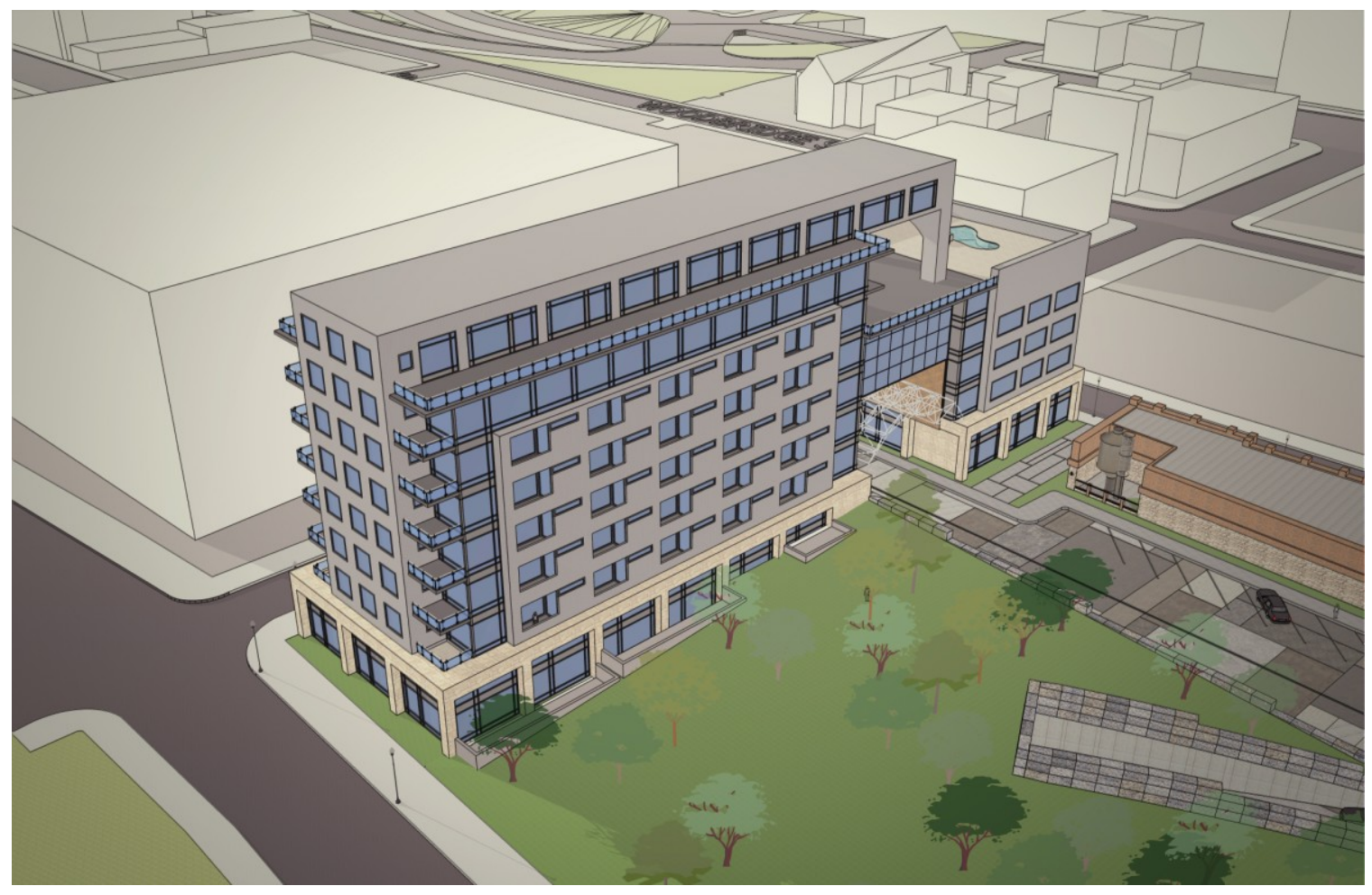

FIG. 62 HOTEL VIEW FROM OVERHEAD: McKeracher, Colleen, 2014.

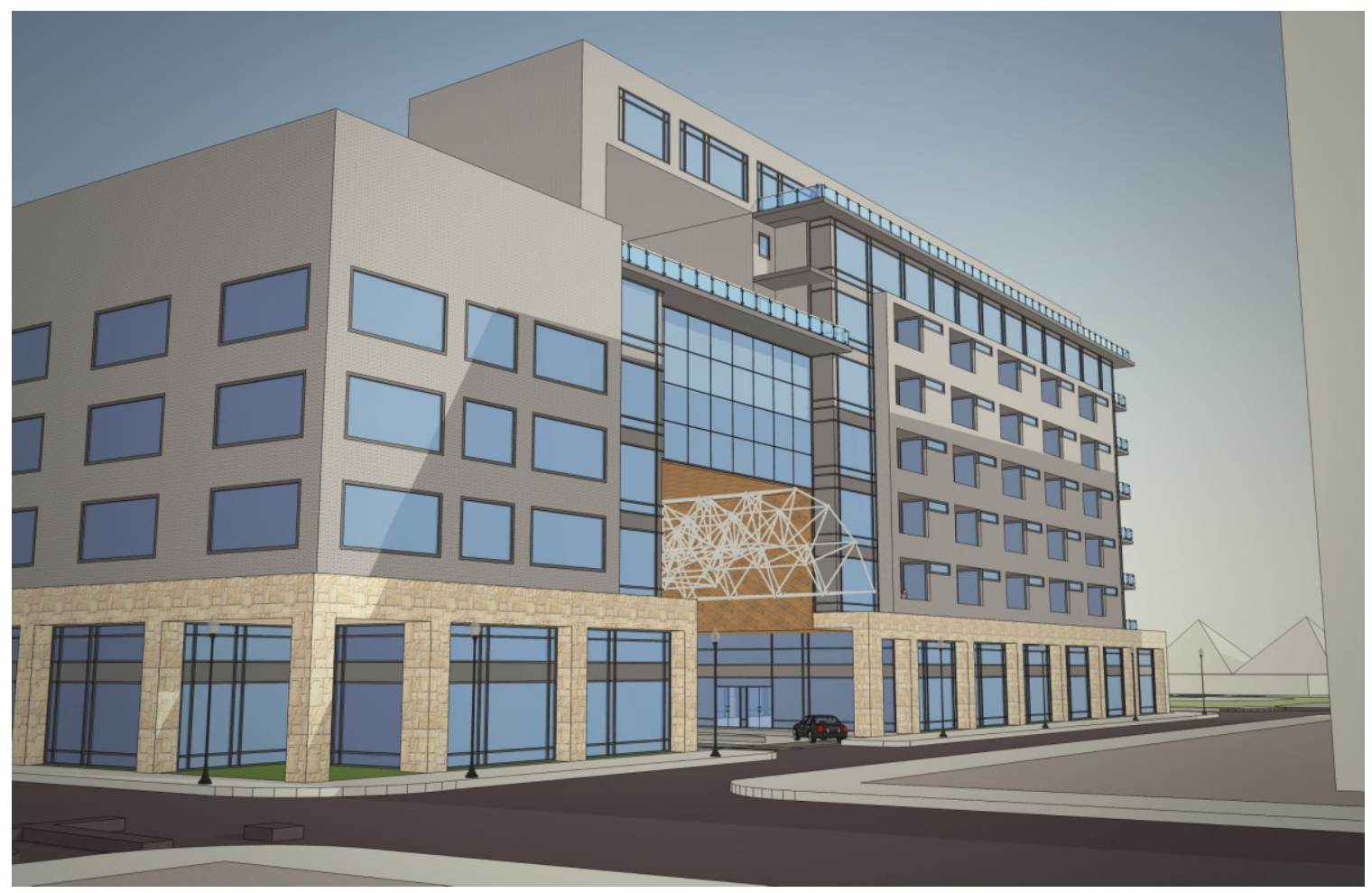

FIG. 63 HOTEL VIEW FROM FRANKLIN AND RIVARD: McKeracher, Colleen, 2014. 


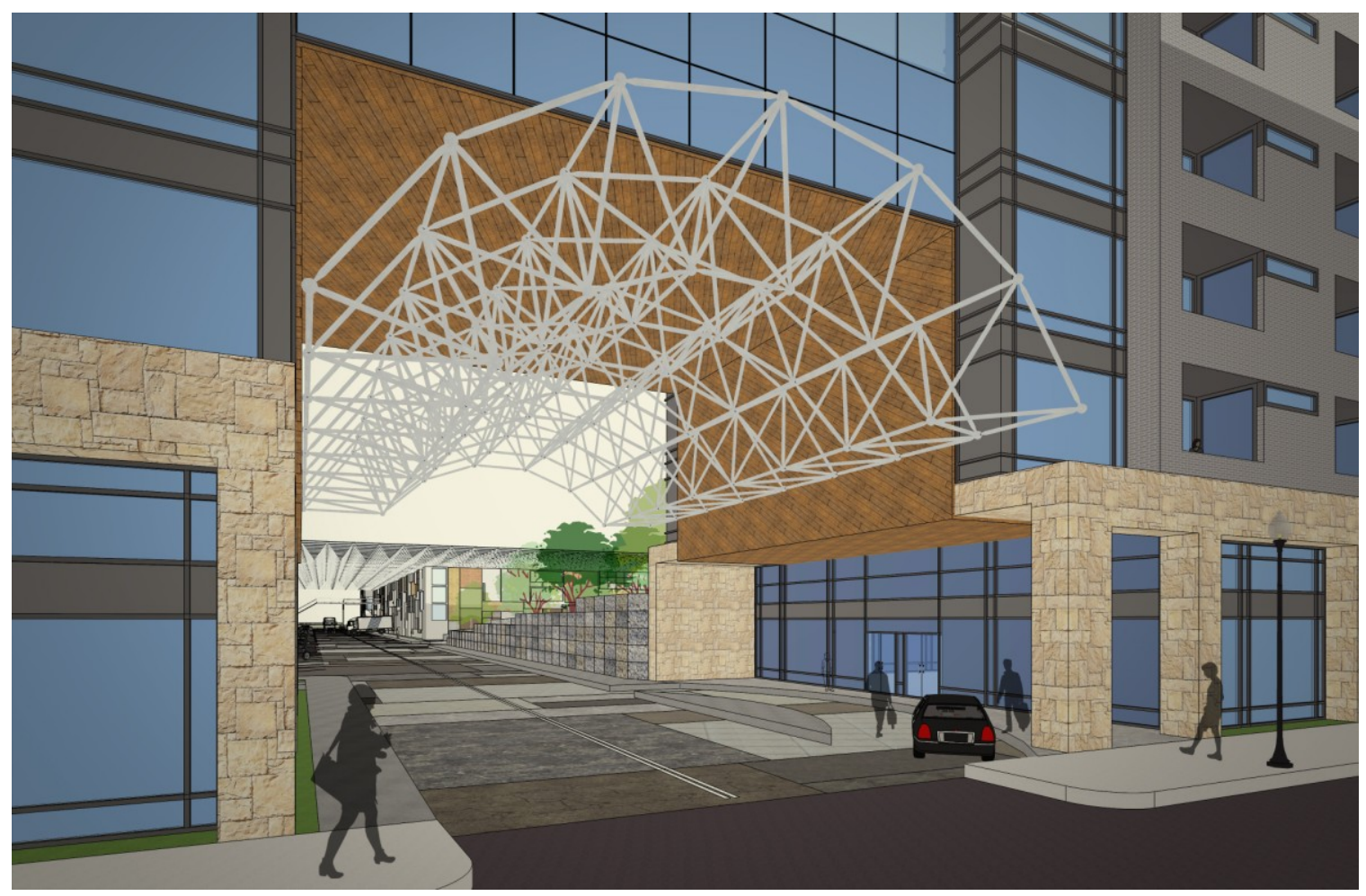

FIG. 64 HOTEL VIEW FROM RIVARD STREET: McKeracher, Colleen, 2014.

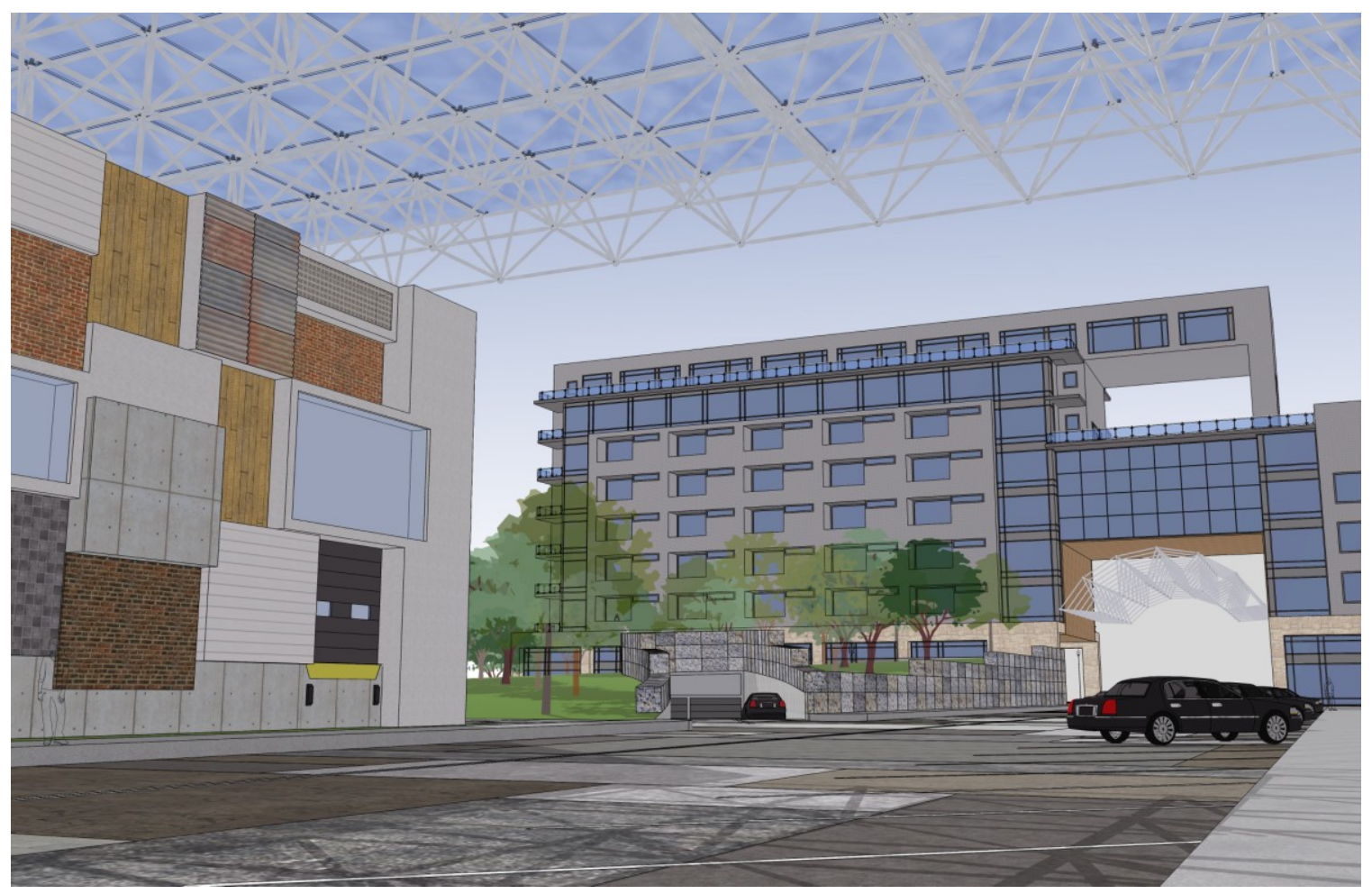

FIG. 65 HOTEL VIEW FROM GUOIN: McKeracher, Colleen, 2014. 
4. The microbrewery is granted a sizable space that fronts onto both Franklin Street and the new Guoin Street. The majority of the space will be given over to the brewery itself, to accommodate large machinery, storage, and office space., while the rest of the floor space is devoted to the operation of a restaurant and bar. The microbrewery will utilize salvaged materials to create a timber-framed structure from reclaimed wood. The wood will maintain its rough appearance from its previous usage, thus forming a connection with the trans-historical nature of Wabi-sabi and craft, reminding us of the cyclical nature of life. Exposed ductwork and electrical wiring will allow the building to be reconfigured with ease. This is not only a practical approach but also expresses the belief that materially effective architecture that conserves resources carefully is vital to good design and to good living.

Since Detroit has a history of moving buildings to suit their needs, such as the relocation of the Gem Theatre, this microbrewery could be a building slated for demolition, instead of a new construction. The building would have to be physically sound for this to make sense, and it would be a costly procedure, but the Microbrewery would gain the authentic aesthetic of aged architecture, a sought after appearance within the typology of a brewery. Demolition through migration could help a city in decline to preserve important buildings as well as shrinking their boundaries. Consider the brewery design in FIG. 66 and FIG. 67 as a placeholder for a Detroit building that would be appropriate for relocation. 


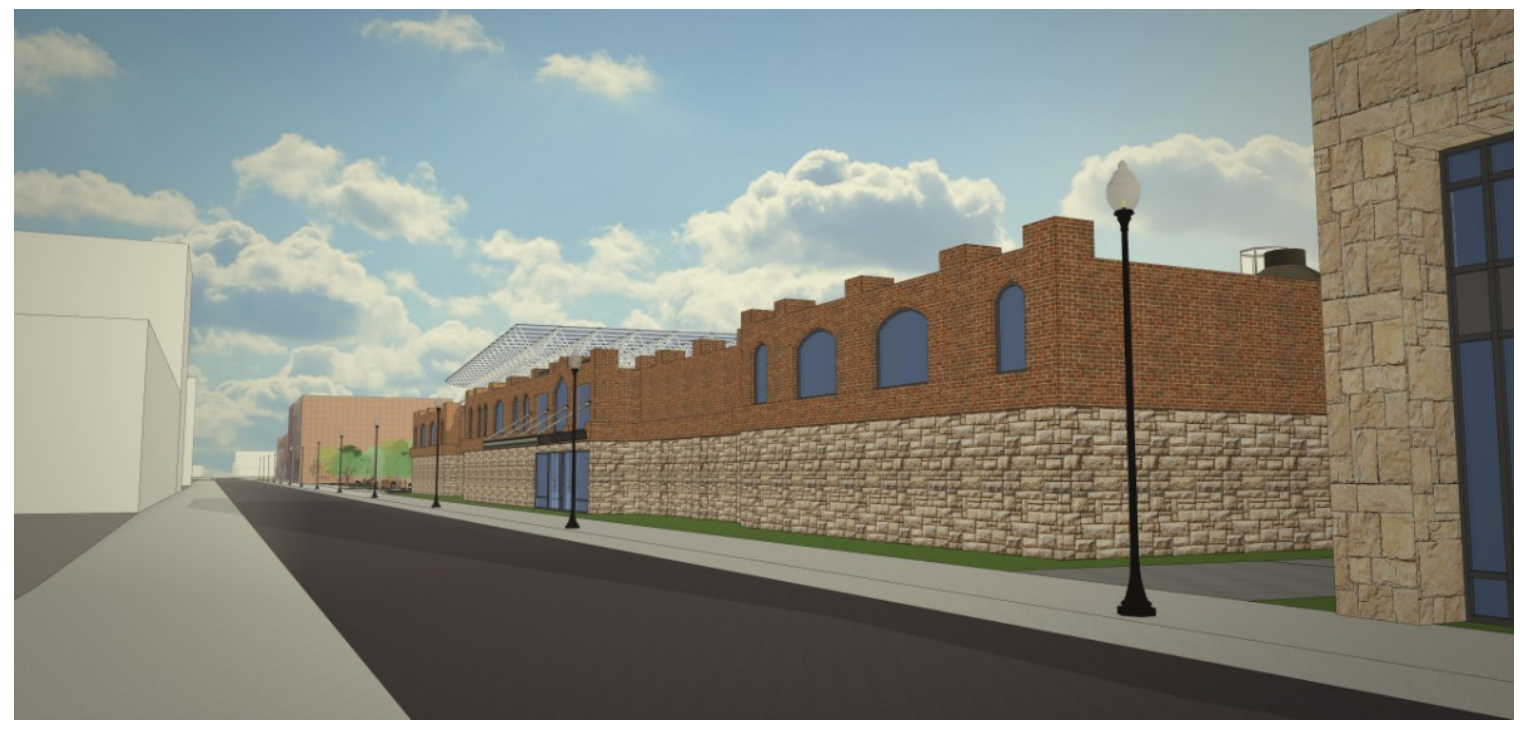

FIG. 66 BREWERY VIEW FROM FRANKLIN STREET: McKeracher, Colleen, 2014.

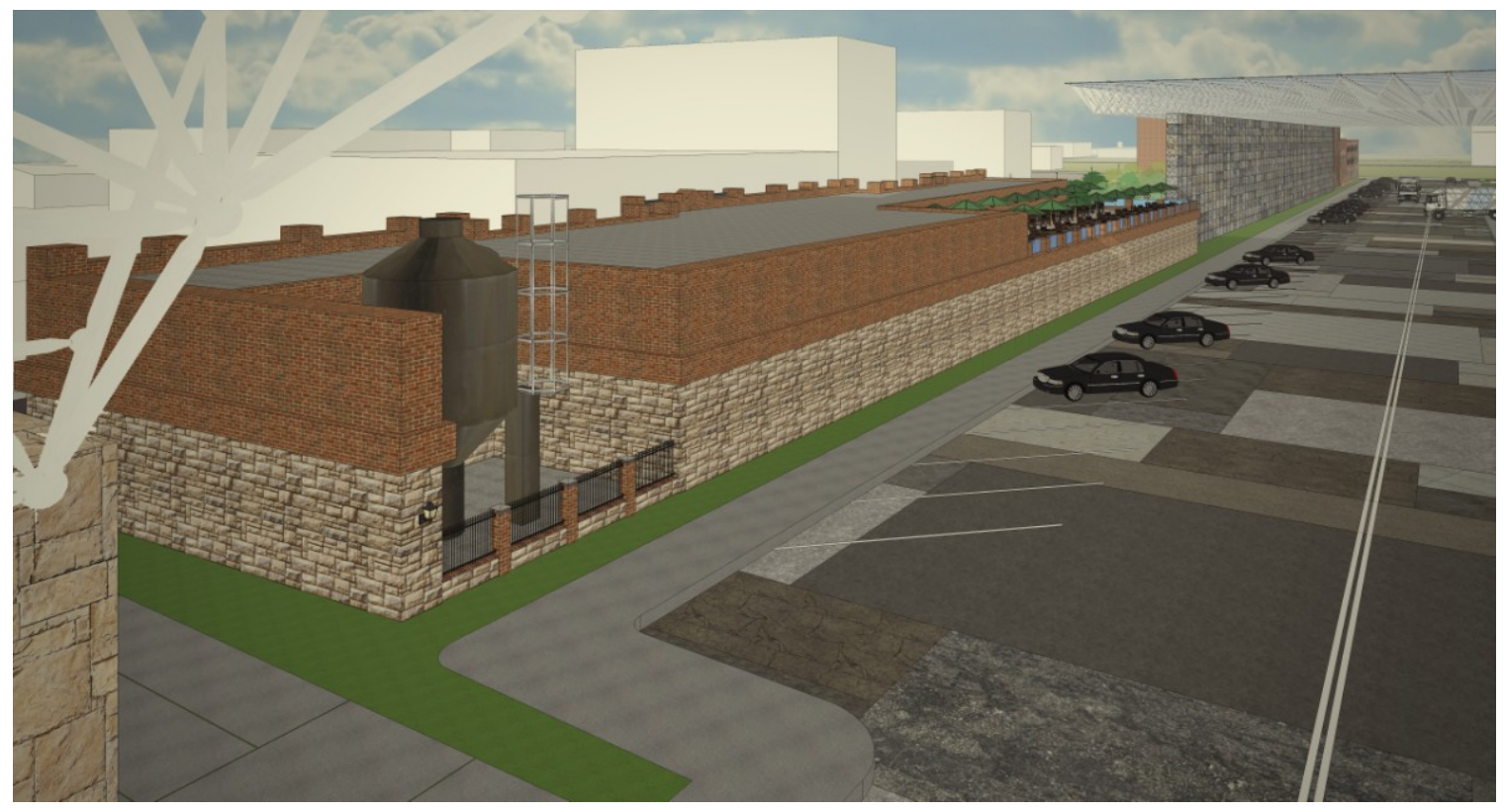

FIG. 67 BREWERY VIEW FROM GUOIN STREET: McKeracher, Colleen, 2014. 


\section{Conclusions Of Part Two}

Post-industrial urban processes affect even the most historically successful industrial cities of the modern age. Detroit illustrates the processes of postindustrial decline vividly, with profound economic and social factors compounding and aggravating its effects. All post-industrial cities throughout the world must at one time confront decay and the ruination of their material fabric in very real ways. Accordingly, insights from the architectural proposition presented in this thesis are intended to be applicable to other places.

In a world of rapid changes, driven by market forces, our society idolizes the new and disposes of the old. But is it not useful and fruitful, to expose the spoils of our built culture, to celebrate them, and to find ways to incorporate them into participatory and city-building events? This is the logic behind the notion of a public salvage yard: there, the material detritus recovered from disassembled buildings would be organized and made coherent once again, as a public and social space. The public salvage yard makes visible the cycles of construction, weathering, and decay of cities and of post-industrial cities in particular. In cities with a rich past of industrial production, the public salvage yard also becomes an archive of sorts, documenting the history of construction techniques and materials proper to a particular place and time.

Today, the citizens of Detroit must live with constant reminders of the fleeting nature of time, and of the fragility of urban systems. Detroiters must constantly reflect on their city - on its meaning and on its connections with broader political, economical and environmental forces -- because they are surrounded by 
the effects of ruination. The 'Detroit Future City' plan targets specific areas for managed decline, and therefore asks of Detroiters to take a position regarding decline. In light of this, the public salvage yard proposes to reinterpret the act of demolition as a necessary step towards revitalization, and as a positive gesture on a journey of return to economic, social and environmental vitality. 'Detroit Future City' requires some Detroiters to accept the loss of their own plots of land and homes as a necessary sacrifice for the revitalization of the city as a whole.

In conclusion of this thesis, critical reflection and evaluation upon the " $\mathrm{D}$ Build Detroit" proposition is called for. In hindsight, reflecting on the design as a whole for the site block bounded by Atwater, Riopelle, Franklin and Rivard Street, some parts of the project emerge as more successful than others. The project was torn between two conflicting goals: solving an urban question with the redesign of an entire urban block in Detroit's waterfront district, and a disassemblable design at the scale of building construction detail. The project's urban and architectural aspirations were in some ways at odds. Specifically, the urban question of reconfiguring an entire block in a district that is now part of an ongoing revitalization effort required that the design make sense of many relationships and adjacencies. These included the relationship to the approach from the downtown, the connection to the Dequindre Cut, the demand for parking from a vehicleoriented culture, the sizeable blocks and the requirement to correspond with the green amenities of the River Walk and a possible residential development. The hotel and brewery elements of the proposed urban block were responses to these issues. However, their architectural manifestations and building logics did not, in the end, 
illustrate the themes of dismantling and reuse in sufficiently strong and convincing ways. These elements were included in an effort to fully develop the site within the urban context, but it is fair to say that their architectural expressions responded to more conventional approaches to site anchoring and visual urban presence. On the other hand, the architecture and detailing employed in the design of the public salvage yard component of this project directly illustrated the possibilities of a new kind of building logic: one that is anchored in reuse and recovery, rather than on newness. Gabion walls filled with crushed concrete from buildings and artifacts found throughout the city, for example, become vivid expressions of an innovative and optimistic approach toward urban decline and transformation. These recovered elements constitute a gesture of endorsement, urging the citizens of Detroit to discover new and relevant ways to make sense of their shrinking city. A public salvage yard of this kind could be a positive influence in shrinking cities elsewhere. In this sense, the thesis project presented in the preceding pages would be clearer and more poignant if it focused on the building details instead of on the urban block issues. Innovative and thoughtful techniques for reusing disassembled building parts could be brought to other cities during their respective deconstruction periods, while the conclusions at the urban scale pertaining to the specific block (including site design and program development), cannot be transported as readily. The attention to program development might have been better spent on the development of details and construction systems following the principles of disassembly discussed within the thesis. Some questions worth exploring in the future include: how to successfully recover large sections of brick walls from 
demolition sites, and transport them to new construction sites, so as to recover the labor and materials of brick construction affordably; how to create an airtight seal between elements without the use of sealants; how the principles of disassembly might conflict with each other and how to appease the majority of principles; and how to create an appropriate foundation without relying on poured concrete.

The approach used in this thesis for the design of the National Demolition Associations Headquarters - whose footprint is derived from the former Detroit Screw Works - should also be re-evaluated. With its emphasized joints, the building lends itself to being separated into smaller individual buildings that could eventually be relocated from where it no longer makes sense to where it might be better suited. The building's formal logic did lend itself to reuse in the future and in order to appease the program of a headquarters it was designed for disassembly, although only at the massing scale. The headquarters brand new materiality and sleek appearance, while implemented in order to help the Association distinguish itself in the public eye, contradicted the project's intentions in other ways. It focused the buildings design around its program while instead, it might of engaged the design with the details of its construction, investigating the principles of disassemble in depth rather than just for the building's massing.

This thesis attempted to explore the issues of demolition on both the urban and built scales. Had the final project been less devoted to the urban aspirations it could have alternatively delved into reinventing conventional approaches in new construction designs. It would make complete sense for this new building science to come out of Detroit, the city that has historically made profound contributions to the 
art of contemporary making. The language and ad hoc aesthetic employed for the design of the public salvage yard points to this new direction. With its patchwork floor and walls made of large sections cut from other buildings, the salvage yard pays homage to past efforts and labour, and its beauty comes out of a sort of 'ugliness.' In conventional practice, the use of all-new materials ensures material control and quality; additionally, computer software such as BIM (Building Information Modeling), assume the use of stock materials and predefined details, making the production of construction documents easier and quicker. To be sure, the practice of reusing portions of buildings already in existence does not fit neatly with these techniques. Because this is so does not mean, however, that we should not try. An alternate approach to the making of buildings that makes better sense of the material cycle of construction and destruction is vital. By incorporating into new buildings reused parts, and by pulling materials from many different sources, the architecture created will represent a desired change in the built environment: one that reflects social priorities favoring a more reverent approach toward material consumption. The ad hoc design approach registers local materials and vernacular memory, and produces buildings with evocative patina and texture inherited from previous uses. And where in conventional practice, the architect has the first say in material choices for new buildings, this alternate approach - where buildings in demolition, in all their specificity, provide the material palette -- gives to the built fabric itself a 'voice' in the making of new buildings. The available materials in a given place, with its given crop of no longer needed buildings, are allowed to lead the design. 
To demonstrate how the design might have developed further, FIG. 68 shows the salvage yard existing as the only program on the site. The roof covers the majority of the site, cutting back just for the existing buildings. With such a large roof, the salvage yard becomes a prominent feature along Atwater Street. (FIG. 69) The gabion walls have been thickened to increase the stability of the structure and in respond to the roof's increased size. Along Rivard Street the salvage yard cuts back to create a lawn, as a way of connecting with the front lawn of the River Walk and nearby visitor center across Atwater Street. (FIG. 70) In this modified design, which includes only a salvage yard, Guoin Street retains the same role as in the previous scheme, still acting as the primary means of access and parking for the salvage yard. (FIG. 71) In this alternate modified proposition for a salvage yard landscape, the site gives a hopeful second chance to the built fabric of Detroit, a fabric that worked so hard in the past and that deserves for a new life in the present. 


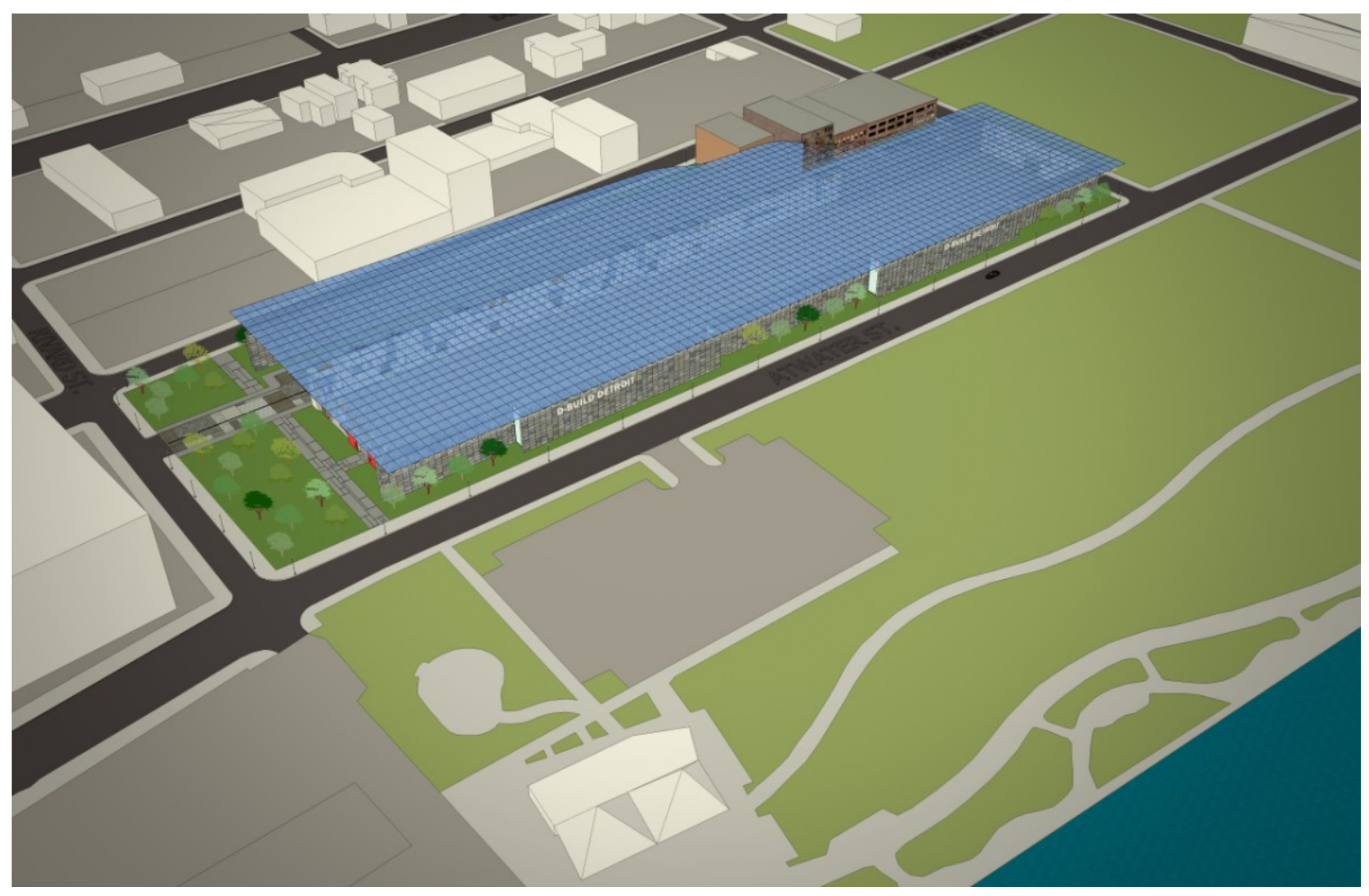

FIG. 68 SALVAGE YARD REVISION OVERHEAD: McKeracher, Colleen, 2014.

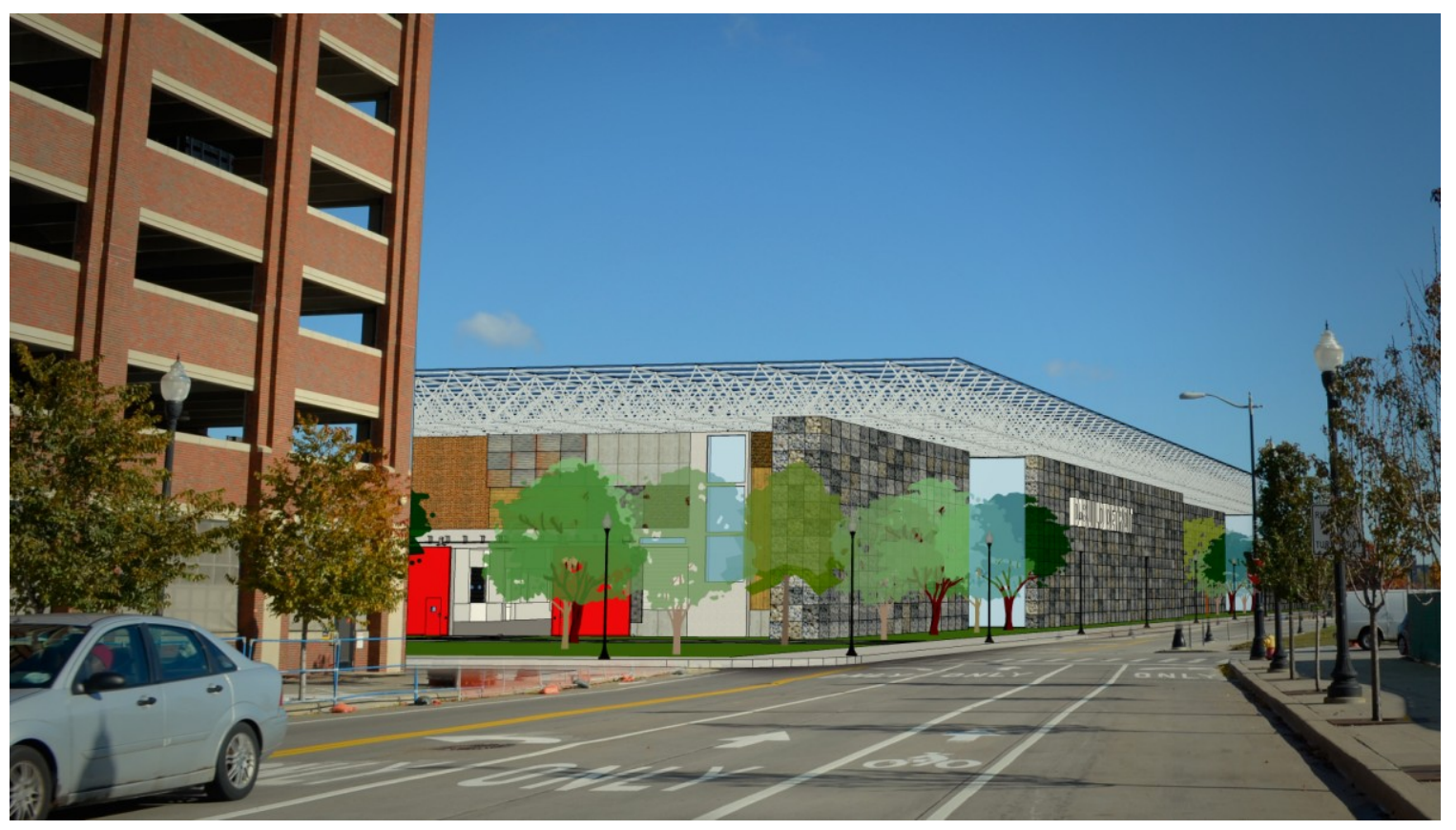

FIG. 69 SALVAGE YARD REVISION VIEW FROM ATWATER: McKeracher, Colleen, 2014. 


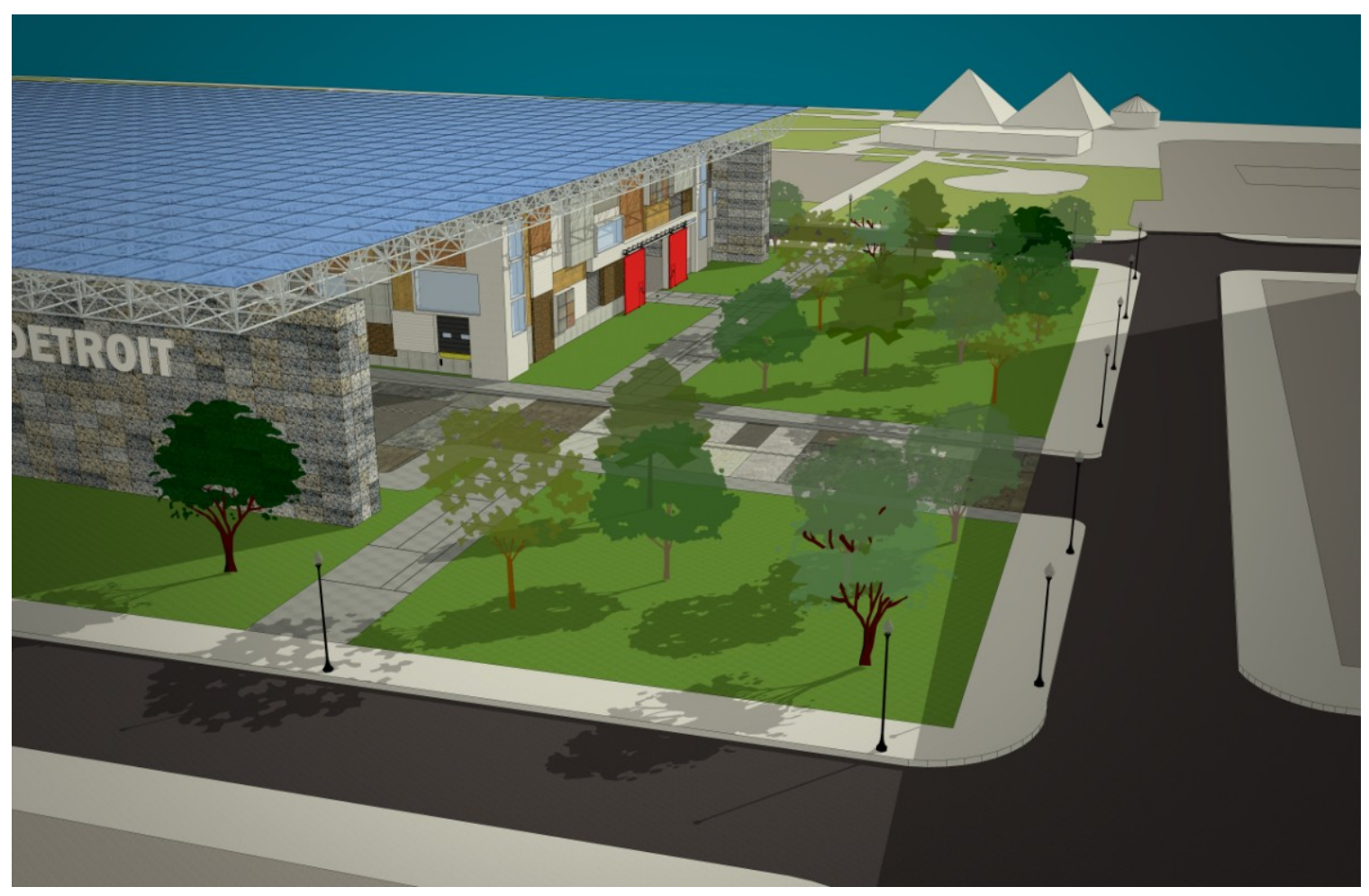

FIG. 70 SALVAGE YARD REVISION VIEW FROM RIVARD: McKeracher, Colleen, 2014.

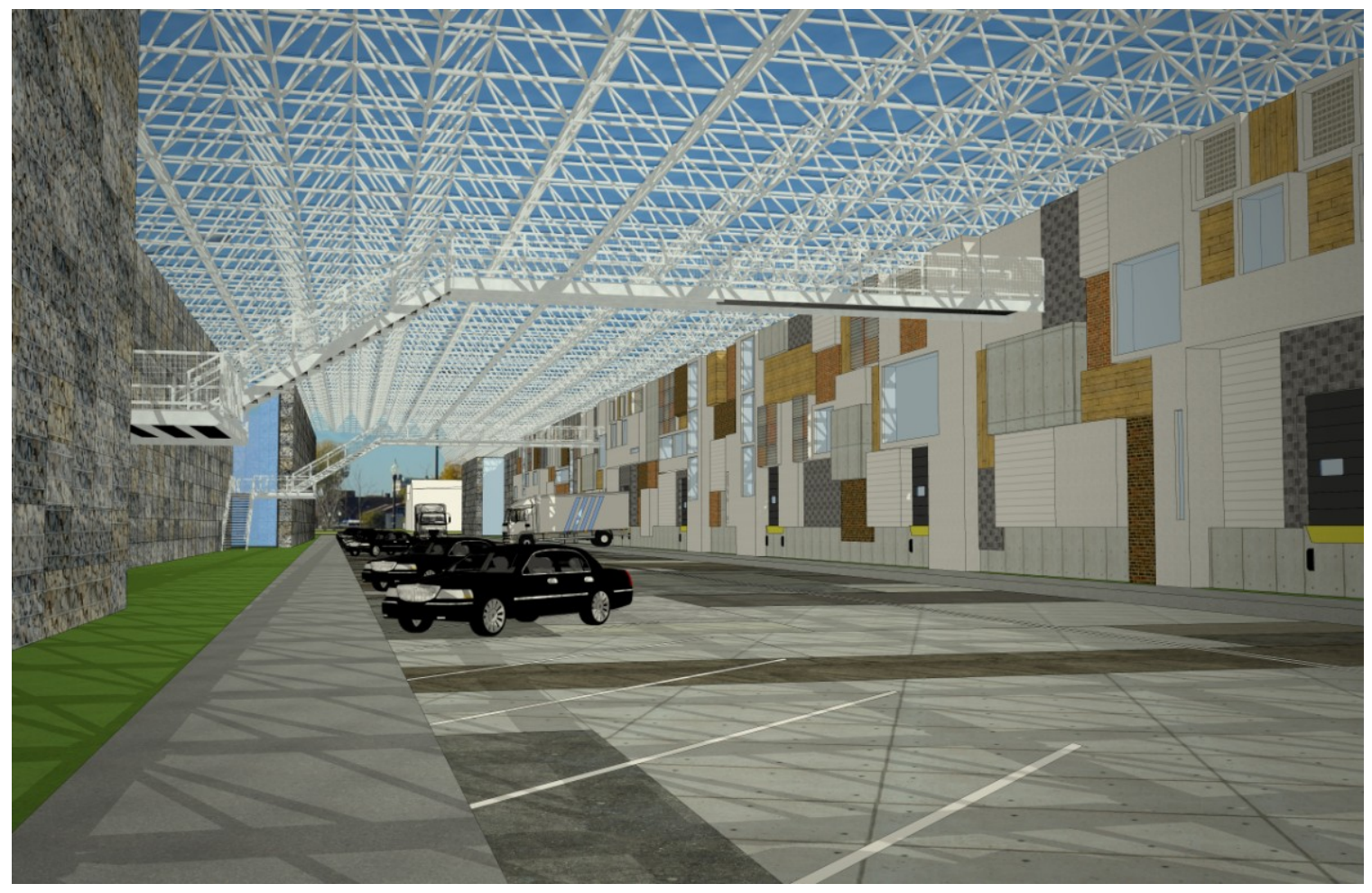

FIG. 71 SALVAGE YARD REVISION VIEW EAST FROM GUOIN: McKeracher, Colleen, 2014. 


\section{List of Figures}

FIG. 1 DETROIT ANNEXATION GROWTH 1915 - 1926: Saunder, Pete. The Reasons behind Detroit's Decline. Last Modified February 21st 2012. Accessed February $2014<$ http://www.urbanophile.com/2012/02/21/the-reasons-behinddetroits-decline-by-pete-saunders/>. 13

FIG. 2 HOW HOUSTON GREW: Carr, Jay. HOUSTON AT 175 How Houston Grew. Houston Chronicle: 22. 2011. 14

FIG. 3 SKYLINE: "Detroit Blight Authority." Photos. N.p., n.d. Web. 13 Feb. 2014. 14

FIG. 4 COMPARATIVE COST BREAKDOWN: Marshall, Terry. Housing Deconstruction Project: 1659 Kilborn Avenue, Ottawa. CMHC. Ottawa, 1996. 30

FIG. 5 REVENUES BREAKDOWN: Marshall, Terry. Housing Deconstruction Project: 1659 Kilborn Avenue, Ottawa. CMHC. Ottawa, 1996. 31

FIG. 6 THE MAIN SANTUARY AND THE WEST TREASURE HOUSE, INNER SHRINE (NAIKU): Watanabe, Yoshio. CCA Collection, Ise Shrine Japan, 1953. 36

FIG. 7 THE EAST TREASURE HOUSE, INNER SHRINE (NAIKU): Watanabe, Yoshio. CCA Collection, Ise Shrine Japan, 1953. 37

FIG. 8 THE WEST TREASURE HOUSE, OUTER SHRINE (GEKU): Watanabe, Yoshio. CCA Collection, Ise Shrine Japan, 1953. 37

FIG. 9 THE SOUTHEAST CORNER OF THE HALL OF THE DAILY OFFERING, OUTER SHRINE (GEKU): Watanabe, Yoshio. CCA Collection, Ise Shrine Japan, 1953 or 1960. 38

FIG. 10 DIAGRAM OF VARIOUS COMMUNITY FUNCTIONS FUN PALACE: Price, Cedric. From Agit-Prop to Free Space.1961. 41

FIG. 11 INTER ACTION CENTRE: Mathews, Stanley. 1977. 42

FIG. 12 INTER ACTION CENTRE: Mathews, Stanley. 1977. 42

FIG. 13 INTER ACTION COMMUNITY ARTS CENTRE: AERIAL VIEW: Cedric Price Fonds. CCA Collection. 1970-1981. 43

FIG. 14 AERIAL VIEW OF SEQUIN ISLAND: Doisneau, Robert. Gamma-Rapho Collection via Getty Images. Paris, France. 193545

FIG. 15 AERIAL DESIGN OF ILE SEGUIN: 1024 Architecture, 2011. 46 
FIG. 16 LES GRANDES TABLES DE L"ILE SEGUIN EXTERIOR: Pelleschi, Brice. 1024 Architecture, 2011. 46

FIG. 17 LES GRANDES TABLES DE L"ILE SEGUIN INTERIOR: Sancereau, C. 1024 Architecture, 2011. 47

FIG. 18 CONSTRUCTION PERMITS ISSUED, DETROIT 2006 - 2009: Data Driven Detroit, 2010. Accessed November 2013. <http://datadrivendetroit.org/>. 50

FIG. 19 DEMOLITION PERMITS ISSUED, DETROIT 2006 - 2009: Data Driven Detroit, 2010. Accessed November 2013. <http://datadrivendetroit.org/>. 50

FIG. 20 JUDGE WOODWARD'S PLAN OF THE CITY OF DETROIT: Hull, Abijah. Burton Historical Collection, 1807. 55

FIG. 21 DETROIT DOWNTOWN AERIAL PHOTOGRAPH 1949: Wayne State University. 56

FIG. 22 DETROIT DOWNTOWN AERIAL PHOTOGRAPH 1961 (the first phase of construction of the I-75 freeway and of Lafayette Park, residential development (then known as URMich 1-1, the first urban renewal project in the U.S.) are visible in this aerial): Wayne State University. 57

FIG. 23 DETROIT CITY SIZE COMPARISON: Pitera, Dan. Cultivating the Shrinking City. King, Jason. March 10th 2010. Accessed February 2014. <http://www.terrafluxus.com/archives/408>. 58

FIG. 24 MICHIGAN CENTRAL STATION: Marchand, Yves. Meffre, Romain. Polidori, Robert. Sugrue,Thomas J. The Ruins of Detroit. Göttingen: Steidl, 2010. Cover. 61

FIG. 25 DETROIT FIGURE GROUND: McKeracher, Colleen. 2013. 65

FIG. 26 DETROIT BUS ROUTES: McKeracher, Colleen. 2013. 65

FIG. 27 DETROIT LAND USE: McKeracher, Colleen. 2013. 66

FIG. 28 CONTEXT OF THE SITE: McKeracher, Colleen, 2014. 66

FIG. 29 DETROIT ZONE 2 MAP: Detroit Zoning Ordinance: Chapter 61 of the 1984 Detroit City Code, as Amended. Detroit, MI: City Planning Commission, 16 April 2013. 70

FIG. 30 DETROIT LOOKING DOWN GUOIN STREET FROM RIOPELLE STREET: Mckeracher, Colleen. 2013. 71

FIG. 31 DETROIT GREENWAY TRAIL VIEW (LOOKING SOUTH): East Riverfront Revitalization Implementation Plan, McCormack Baron Salazar, 2012. 71 
FIG. 32 GUOIN MEWS (LOOKING EAST): East Riverfront Revitalization Implementation Plan, McCormack Baron Salazar, 2012. 72

FIG. 33 INTERSECTION OF FRANKLIN AND RIOPELLE: Burton Historical Collection, 1910. 75

FIG. 34 DETROIT SCREW WORKS LITHOGRAPH: Burton Historical Collection. 75

FIG. 35 EATON-CLARK CHEMICAL AND DYES LITHOGRAPH: Burton Historical Collection. 76

FIG. 36 EATON-CLARK CHEMICAL AND DYES PHOTOGRAPH: McKeracher, Colleen. 2013. 76

FIG. 37 DETROIT SCREW WORKS: Cassani, M. Documenting Detroit Collection. 1980. 77

FIG. 38 SANBORN INSURANCE MAPS OF DETROIT VOL. 1: Burton Historical Collection, 1884. 81

FIG. 39 BAIST'S REAL ESTATE ATLAS, SURVEYS OF DETROIT VOL. 1: Burton Historical Collection, 1929. 82

FIG. 40 DETROIT EAST RIVER FRONT: Google Maps, satellite image, 2013. 82

FIG. 41 PALIMPSEST OF THE SITE: McKeracher, Colleen, 2014. 83

FIG. 42 D-BUILD DETROIT AT NIGHT FROM ATWATER: McKeracher, Colleen, 201486

FIG. 43 FORECOURT GARDEN VIEW FROM FRANKLIN STREET: McKeracher, Colleen, 2014. 87

FIG. 44 SITE PLAN: McKeracher, Colleen, 2014. 92

FIG. 45 OVERHEAD: McKeracher, Colleen, 2014. 93

FIG. 46 VIEW FROM GUOIN TO PARKING RAMP: McKeracher, Colleen, 2014. 94

FIG. 47 VIEW FROM RIOPELLE STREET: McKeracher, Colleen, 2014. 95

FIG. 48 N.D.A. HEADQUATERS VIEW FROM ATWATER: McKeracher, Colleen, 2014. 98

FIG. 49 N.D.A. HEADQUARTERS OVERHEAD: McKeracher, Colleen, 2014. 98

FIG. 50 N.D.A. HEADQUARTERS VIEW FROM COURTYARD: McKeracher, Colleen, 2014. 99 
FIG. 51 SALVAGE YARD SECTION: McKeracher, Colleen, 2014. 103

FIG. 52 SALVAGE YARD VIEW FROM ATWATER: McKeracher, Colleen, 2014. 104

FIG. 53 SALVAGE YARD VIEW FROM HOTEL BALCONY: McKeracher, Colleen, 2014. 105

FIG. 54 SALVAGE YARD VIEW FROM GUOIN: McKeracher, Colleen, 2014. 105

FIG. 55 SALVAGE YARD NORTH FACADE: McKeracher, Colleen, 2014. 106

FIG. 56 SALVAGE YARD VIEW FROM LIBRARY ONTO GUOIN: McKeracher, Colleen, 2014. 106

FIG. 57 SPACE FRAME ROOF: McKeracher, Colleen, 2014. 107

FIG. 58 FORECOURT GARDEN VIEW FROM FRANKLIN STREET: McKeracher, Colleen, 2014. 107

FIG. 59 FORECOURT GARDEN VIEW FROM GABION WALL: McKeracher, Colleen, 2014. 108

FIG. 60 FORECOURT GARDEN: McKeracher, Colleen, 2014. 108

FIG. 61 FORECOURT GARDEN OVERHEAD VIEW: McKeracher, Colleen, 2014. 109

FIG. 62 HOTEL VIEW FROM OVERHEAD: McKeracher, Colleen, 2014. 111

FIG. 63 HOTEL VIEW FROM FRANKLIN AND RIVARD: McKeracher, Colleen, 2014. 111

FIG. 64 HOTEL VIEW FROM RIVARD STREET: McKeracher, Colleen, 2014. 112

FIG. 65 HOTEL VIEW FROM GUOIN: McKeracher, Colleen, 2014. 112

FIG. 66 BREWERY VIEW FROM FRANKLIN STREET: McKeracher, Colleen, 2014. 114

FIG. 67 BREWERY VIEW FROM GUOIN STREET: McKeracher, Colleen, 2014. 114

FIG. 68 SALVAGE YARD REVISION OVERHEAD: McKeracher, Colleen, 2014. 121

FIG. 69 SALVAGE YARD REVISION VIEW FROM ATWATER: McKeracher, Colleen, 2014. 121

FIG. 70 SALVAGE YARD REVISION VIEW FROM RIVARD: McKeracher, Colleen, 2014. 122 
FIG. 71 SALVAGE YARD REVISION VIEW EAST FROM GUOIN: McKeracher, Colleen, 2014. 122 


\section{Bibliography}

Adams, Cassandra. "Japan's Ise Shrine and its Thirteen-Hundred-Year-Old Reconstruction Tradition." Journal of Architectural Education 52.1 (1998): 49-60.

Byles, Jeff. Rubble: Unearthing the History of Demolition. New York: Harmony Books, 2005.

Catlin, George B. 1857-1934. The Story of Detroit. Detroit: The Detroit news, 1923.

Chapman, Brian. "Baron Haussmann and the Planning of Paris." The Town Planning Review 24, no. 3 (Oct., 1953): 177-192.

Coaldrake, William Howard. Architecture and authority in Japan. Taylor \& Francis eLibrary ed. London: Routledge, 2002.

Cook, Peter. Archigram. New York: Princeton Architectural, 1999.

Coulmas, Florian. "Eternal Change at the Grand Shrine of Ise." Japan Quarterly 41.1 (1994): 36.

Dam, Minh. "Fifth Ward Neighborhood Undergoes Renaissance." Houston Chronicle, April 7, 2013. http://www.houstonchronicle.com/news/houstontexas/houston/article/Fifth-Ward-neighborhood-undergoes-renaissance4416484.php\#/0 (accessed February 3, 2014).

Davies, Lizzy. "Life after Renault: Ile Seguin to become Paris Culture Hub." The Guardian (Paris), July 9, 2009, sec. World News. http://www.theguardian.com/world/2009/jul/09/paris-il-segiun-regeneration (accessed March 22, 2014).

Debanné, Janine. "Claiming Lafayette Park as Public Housing." In CASE-Hilberseimer/Mies van der Rohe, Lafayette Park Detroit, edited by Waldheim, Charles. 67-80. Munich: Prestel, 2004.

Debanné, Janine. “Landscapes of Contradiction: Mies van der Rohe's Lafayette Park and its Rapport to the City of Detroit." In Building as a Political Act: Proceedings of the 1997 ACSA International Conference, Berlin, May 31-June 4. Washington, DC: ACSA Press, 1997. 
Debanné, Janine. "Luxury and Fate: The Section 8 Presence in Mies van der Rohe's Lafayette Park Apartments, Detroit, MI." In La Città Nuova: Proceedings of the 1999 ACSA International Conference, Rome, 29 May- 2 June. Washington, DC: ACSA Press, 1999.

Debanné, Janine. "Remembering the Towers." In Thanks for the view, Mr. Mies: Lafayette Park, Detroit, edited by Aubert, Danielle, Lana Cavar, and Natasha Chandani. New York, NY: Metropolis Books, 2012.

Detroit (Mich.). City Plan Commission. Preliminary Plan of Detroit. Detroit, MI: City Plan and Improvement Commission, 1916.

Detroit (Mich.). Detroit Zoning Ordinance: Chapter 61 of the 1984 Detroit City Code, as Amended. Detroit, MI: City Planning Commission, 2005.

"Detroit Screw Works." dETROITfUNK. http://detroitfunk.com/?p=4036 (accessed March 24, 2014).

Detroit Trust Company Quarterly, "Michigan's Oldest Industrial Firm," January 1, 1946.

Dubs, A. "The Detroit Screw Works." Faded Detroit. http://fadeddetroit.blogspot.ca/2005/04/detroit-screw-works.html (accessed March 7, 2014).

"East Riverfront." Detroit Riverfront Conservancy. http://detroitriverfront.org/riverfront (accessed March 26, 2014).

Eisenman, Peter. Cities of Artificial Excavation: The Work of Peter Eisenman, 1978 1988. New York, NY: Centre Canadien d'Architecture and Rizzoli International Publ., 1994.

Eisinger, Peter. "Is Detroit Dead?" Journal of Urban Affairs 36, no. 1 (2014): 1-12.

Environmentally Sustainable Buildings - Challenges and Policies. 2003, OECD.

Fabrizi, Mariabruna. "A Building is an Island is a Building: The Ile Seguin Renault Factory in Paris." SOCKS. http://socks-studio.com/2013/12/29/a-building-is-an- 
island-is-a-building-the-ile-seguin-renault-factory-in-paris/ (accessed March 22, 2014).

Flynn, Courtney. "Taking Stock of Detroit Neighborhoods." Drawing Detroit. Center for Urban Studies at Wayne State University, 15 July 2012. Web. 03 Feb. 2014.

Gallagher, John. 2013. Revolution Detroit: Strategies for Urban Reinvention. Detroit, Mich: Wayne State University Press.

"Going green with LEED." Canada Green Building Council. http://www.cagbc.org/Content/NavigationMenu/Programs/LEED/GoingGreenwith LEED/default.htm (accessed March 22, 2014).

Gordon, M, Engineering. Demolition Energy Analysis of Office Building Structural Systems. Merrickville, Ontario: Athena [TM] Sustainable Materials Institute, 1997.

Gorzelany, Jim. "Cities With The Most (And Least) Stolen Cars." Forbes. http://www.forbes.com/sites/jimgorzelany/2013/06/26/cities-with-the-mostand-least-stolen-cars/ (accessed March 23, 2014).

Hiete, Michael, Julian Stengel, Jens Ludwig, and Frank Schultmann. "Matching Construction and Demolition Waste Supply to Recycling Demand: A Regional Management Chain Model." Building Research \& Information 39, no. 4 (2011): 33351.

Jordan, David P. Transforming Paris: The Life and Labors of Baron Haussmann. New York: Free Press, 1995.

Koolhaas, Rem, and Hans-Ulrich Obrist. Project Japan: Metabolism Talks... Ed. Kayoko Ota and James Westcott. Köln: TASCHEN GmbH, 2011..

Koolhaas, Rem, Jennifer Sigler, Bruce Mau, and Hans Werlemann. Small, Medium, Large, Extra-large. New York: Monacelli, 1998.

Lehmann, Steffen, and Robert Crocker. Designing for zero waste: consumption, technologies and the built environment. London: EarthScan, 2012.

Manheshwari, Tanvi. "Redefining Shrinking Cities." The Berkeley Planning Journal 26 (2013). http://ced.berkeley.edu/bpj/2013/12/redefining-shrinking-cities/ (accessed March 26, 2014). 
Marshall, Terry. Housing Deconstruction Project: 1659 Kilborn Avenue, Ottawa. Ottawa: CMHC, 1996.

Matarrese, Lynne. "A Brief History of Levittown, New York." Levittown Historical Society. http://www.levittownhistoricalsociety.org/history.htm (accessed May 5, 2014).

Mathews, J. Stanley. From Agit-Prop to Free Space: The Architecture of Cedric Price. London: Black Dog Pub. Ltd., 2007.

McGrail, Lucas C. "Louis Kamper." Historic Detroit. N.p., n.d. Web. 09 Jan. 2014.

Ming-Zhi, Anton. "Construction \& Demolition Waste Management: From Japan to Hong Kong". 2006. Griffin's View on International and Comparative Law. 7 (2): 15-45.

Muller, Joann. "Bill Pulte: From Home Builder to Detroit's Unlikely Blight Buster." Forbes. Forbes Magazine, 09 Oct. 2013. Web. 03 Feb. 2014.

O'Connor, J. 2004. Survey on actual service lives for North America buildings. Presented at Woodframe Housing Durability and Disaster Issues Conference, Las Vegas, October 2004.

OECD. Environmentally Sustainable Buildings: Challenges and Policies. OECD Publishing, 2003.

Olsen, John. "Urban Landscapes." The Life and Death of the Big Box. http://urbanlandscapes.info/2011/01/31/the-life-and-death-of-the-big-box/ (accessed March 26, 2014).

Powell, Richard R. Wabi Sabi Simple. Avon, Mass.: Adams Media, 2005.

Pure Detroit. "The Dequindre Cut: Two centuries of Transformation \& More to Come." Pure Detroit. http://www.puredetroit.com/index.php/history/thedequindre-cut-two-centuries-of-transformation-292.html (accessed March 25, 2014).

Reindl, JC. "\$60M East Riverfront Development in Detroit to Bring Housing, Streetscape." Detroit Free Press, July 23, 2013, sec. Michigan Business. http://www.freep.com/article/20130723/BUSINESS04/307230014/Detroit- 
riverfront-development-apartments-291-units-Globe-Building (accessed March 24, 2014).

Roberts, Sam. "When the City's Bankruptcy Was Just a Few Words Away." The New York Times, December 31, 2006, sec. N.Y./ Region.

Schmalzreidt, Fred. R. Compiled Ordinances of Detroit of 1912. Detroit, Michigan: Houghton-Jacobson Print Co. 1912.

Schramm, Kenneth. Detroit's street railways. Charleston, SC: Arcadia, 2006.

Seike, Kiyoshi. The Art of Japanese Joinery. 1st English ed. New York: J. Weatherhill, 1977.

Slade, Giles. Made to break: technology and obsolescence in America. Cambridge, Mass.: Harvard University Press, 2006.

The Asahi Shimbun. "Historic Ise Jingu gears up for vicennial 'big move'." The Asahi Simbun (Japan), September 25, 2013, sec. Social Affairs. https://ajw.asahi.com/information/about_us/ (accessed March 25, 2014).

Touw, Katrina. University of Waterloo, School of Architecture. "Firmitas Re-Visited: Permanence in Contemporary Architecture." University of Waterloo, 2006.

"Vision \& Mission." Detroit Riverfront Conservancy. http://detroitriverfront.org/our-story/vision-mission (accessed March 26, 2014).

Williams, Jeremy. Detroit: The Black Bottom Community. Charleston, SC: Arcadia Pub., 2009.

Wilson, Richard. "A History of the Detroit Riverfront." RAWblog. http://www.richwdesign.com/Riverfront_History.pdf (accessed March 23, 2014).

Woodford, Arthur M. This is Detroit, 1701-2001. Detroit: Wayne State University Press, 2001.

Wright, Gwendolyn. Building the Dream: A Social History of Housing in America. London: MIT, 1983. 